\title{
Kantis: A new Australopithecus site on the shoulders of the Rift Valley near Nairobi, Kenya
}

\section{$\operatorname{AUTHOR}(S)$ :}

Mbua, Emma; Kusaka, Soichiro; Kunimatsu, Yutaka; Geraads, Denis; Sawada, Yoshihiro; Brown, Francis H.; Sakai, Tetsuya; ... Bobe, René; Jicha, Brian; Nakatsukasa, Masato

\section{CITATION:}

Mbua, Emma ... [et al]. Kantis: A new Australopithecus site on the shoulders of the Rift Valley near Nairobi, Kenya. Journal of Human Evolution 2016, 94: 28-44

\section{ISSUE DATE:}

2016-05

URL:

http://hdl.handle.net/2433/209815

\section{RIGHT:}

(c) 2016. This manuscript version is made available under the CC-BY-NC-ND 4.0 license

http://creativecommons.org/licenses/by-nc-nd/4.0/; The full-text file will be made open to the public on 1 May 2017 in accordance with publisher's 'Terms and Conditions for Self-Archiving': この論文は出版社版でありません。引用の際に は出版社版をご確認ご利用ください。; This is not the published version. Please cite only the published version. 
Kantis: A new Australopithecus site on shoulders of the Rift Valley near Nairobi, Kenya

Emma Mbua ${ }^{\mathrm{a},}{ }^{*}$, Soichiro Kusaka ${ }^{\mathrm{b},}$ Yutaka Kunimatsu ${ }^{\mathrm{c}}$, Denis Geraads ${ }^{\mathrm{d}}$, Yoshihiro Sawada ${ }^{\mathrm{e}}$ Francis H. Brown ${ }^{\mathrm{f}}$, Tetsuya Sakai ${ }^{\mathrm{g}}$, Jean-Renaud Boisserie ${ }^{\mathrm{h}}$, Mototaka Saneyoshi ${ }^{\mathrm{i}}$, Christine Omuombo $^{\mathrm{j}}$, Samuel Muteti ${ }^{\mathrm{k}}$, Takafumi Hirata ${ }^{1}$, Akira Hayashida ${ }^{\mathrm{m}}$, Hideki Iwano ${ }^{\mathrm{n}}$, Tohru Danhara $^{\mathrm{n}}$, René Bobe ${ }^{\mathrm{o}}$, Brian Jicha ${ }^{\mathrm{p}}$, Masato Nakatsukasa ${ }^{\mathrm{q}}$,

${ }^{\mathrm{a}}$ Department of Biological Sciences, Mount Kenya University, P.O Box 342-00100, Thika, Kenya

${ }^{\mathrm{b}}$ Museum of Natural and Environmental History, Suruga, Shizuoka 422-8017, Japan

${ }^{\mathrm{c}}$ Faculty of Business Administration, Ryukoku University, Fushimi, Kyoto 612-8577, Japan

d Sorbonne Universités - CR2P-MNHN, CNRS, UPMC-Paris 6 - CP 38, Muséum National d'Histoire Naturelle, 8 rue Buffon, F-75231 Paris Cedex 05, France;

Max Planck Institute for Evolutionary Anthropology, Department of Human Evolution

Deutscher Platz 6 - D-04103 Leipzig - Germany

e402-1 Fukushima, Kurashiki 710-0048, Japan

${ }^{\mathrm{f}}$ Department of Geology \& Geophysics, University of Utah, Salt Lake City, UT, 84112, USA

${ }^{\mathrm{g}}$ Department of Geoscience, Shimane University, Matsue 690-8504, Japan

${ }^{\mathrm{h}}$ Institut de Paléoprimatologie, Paléontologie Humaine : Evolution et Paléoenvironnements (CNRS and Université de Poitiers), 6, rue Michel Brunet, 86073 Poitiers CEDX 9, France; Centre Français des Etudes Ethiopiennes (CNRS and Ministère des Affaires Etrangères), P.O BOX 5554, ADDIS ABABA, ETHIOPIA

${ }^{i}$ Department of Biosphere-Geosphere Science, Okayama University of Science, Kita, Okayama 700-0005, Japan

${ }^{\mathrm{j}}$ Department of Geology, University of Nairobi, 30197-001001, Nairobi, Kenya

${ }^{\mathrm{k}}$ Department of Earth Sciences, National Museums of Kenya, P.O Box 40658-00100, Nairobi, Kenya

${ }^{1}$ Division of Earth and Planetary Sciences, Kyoto University, Sakyo, Kyoto 606-8502, Japan

${ }^{\mathrm{m}}$ Department of Environmental Systems Science, Doshisha University, Kyotanabe, Kyoto 6100321 , Japan

${ }^{\mathrm{n}}$ Kyoto Fission-Track Co., Ltd., Kita, Kyoto 603-8832, Japan

${ }^{\circ}$ Departamento de Antropología, Universidad de Chile, Santiago, Chile 
${ }^{\mathrm{p}}$ Department of Geology and Geophysics, University of Wisconsin-Madison, 1215 W. Dayton Street, Madison, WI 53706, USA

${ }^{\mathrm{q}}$ Laboratory of Physical Anthropology, Kyoto University, Sakyo, Kyoto 606-8502, Japan

Corresponding authors

E-mail addresses: enmbua@gmail.com (E. Mbua);

nakatsuk@anthro.zool.kyoto-u.ac.jp (M. Nakatsukasa)

Keywords

Pliocene, Hominin, Fossils, Carbon stable isotope, Paleoenvironment 


\begin{abstract}
Most Plio-Pleistocene sites in the Gregory Rift Valley that have yielded abundant fossil hominins lie on the Rift Valley floor. Here we report a new Pliocene site, Kantis, on the shoulder of the Gregory Rift Valley, which extends the geographical range of Australopithecus afarensis to the highlands of Kenya. This species, known from sites in Ethiopia, Tanzania, and possibly Kenya, is believed to be adapted to a wide spectrum of habitats, from open grassland to woodland. The Kantis fauna is generally similar to that reported from other contemporaneous $A u$. afarensis sites on the Rift Valley floor. However, its faunal composition and stable carbon isotopic data from dental enamel suggest a stronger $\mathrm{C}_{4}$ environment than that present at those sites. Although the Gregory Rift Valley has been the focus of paleontologists' attention for many years, surveys of the Rift shoulder may provide new perspective on African Pliocene mammal and hominin evolution.
\end{abstract}




\section{Introduction}

Australopithecus afarensis is known from East African sites (Fig. la) dated between 3.7 Ma and 3.0 Ma (Brown et al., 2013) and regarded by some as ancestral to Homo and Paranthropus. The species has a wider distribution and evidently a greater tolerance toward relatively open and arid environments dominated by $\mathrm{C}_{4}$ grasses than does the preceding $\mathrm{Au}$. anamensis (Bedaso et al., 2013; Cerling et al., 2013). As reconstructed, paleohabitats of Au. Afarensis include a wide range of environments: for example, heterogeneous woodland at Laetoli (Kingston and Harrison, 2007; Harrison, 2011; Kingston et al., 2011), a mosaic of woodland and shrubland at Hadar (Reed, 2008), a mosaic of relatively open and mesic habitats at Dikika (Alemseged et al., 2005; Bedaso et al., 2013), and a bushland/woodland with floodplain grassland at Maka (White et al., 1993).

Here we report a new fossil locality, Kantis Fossil Site (KFS) on the outskirts of Nairobi, which is a Pliocene hominin site recognized on shoulder of the Gregory Rift Valley that has yielded fossils of $A u$. Afarensis and abundant remains of other vertebrates. The presence of $A u$. afarensis at KFS extends the geographical range of Au. afarensis to the highlands of Kenya and suggests that this species found suitable habitats in the Kenyan highlands. We provide geology and geochronological information for KFS, describe the morphology of hominin specimens, and present paleoenvironmental implications based on the faunal assemblage and stable carbon isotopic data of herbivorous mammalian dental enamel.

\section{Methods}

${ }^{40} \mathrm{Ar}{ }^{39} \mathrm{Ar}$ age determination and glass composition

Samples of the Kantis Basalt ("Ngongankaratite and tannbuschite" in Saggerson [1991]; see Geology section) and the Lower Kerichwa Tuff (Guth and Wood, 2011) were collected for ${ }^{40} \mathrm{Ar} /{ }^{39} \mathrm{Ar}$ age determination. Following gentle disaggregation in a mullite mortar, feldspar was concentrated from the Lower Kerichwa Tuff by repeated flotation in water, followed by magnetic separation on a Frantz Isodynamic separator. Individual grains were handpicked from the concentrate under a binocular microscope, avoiding those that were discolored or cloudy. The selected grains were then bathed in a 5\% HF solution in an ultrasonic bath for 5 minutes to remove glass attached to the surface, and dried in an oven at $80^{\circ} \mathrm{C}$. Basalt samples were crushed, 
and fragments free of obvious phenocrysts were used for argon analysis. Samples were loaded into aluminum packets and placed into $1.5 \mathrm{~cm}$ diameter aluminum discs and co-irradiated with flux monitors for 4 hours at the Oregon State University TRIGA reactor in the Cadmium-Lined In-Core Irradiation Tube (CLICIT). Sanidine from the Fish Canyon Tuff (age 28.201 Ma; Kuiper et al., 2008) was used as the neutron fluence monitor. At the University of Wisconsin-Madison Rare Gas Geochronology Laboratory, samples and standards were fused using a $25 \mathrm{~W} \mathrm{CO}_{2}$ laser following the methods of Smith et al. (2008). Mass discrimination was assessed by analysis of ${ }^{40} \mathrm{Ar} /{ }^{36} \mathrm{Ar}$ air pipette aliquots throughout the analytical session and was calculated relative to a ${ }^{40} \mathrm{Ar} /{ }^{36} \mathrm{Ar}$ ratio of 295.5 (Steiper and Jager, 1977). Compositions of glass from the tuff samples obtained from the KFS were determined by electron microprobe using methods described in (Nash, 1992).

\section{Zircon U-Pb age determination}

Samples were taken from the trachytic tuff and the mudflow deposit in the fossiliferous bed for zircon $\mathrm{U}-\mathrm{Pb}$ age determination. Zircons from two volcanic samples (tuff and volcanic mud flow deposit) were separated using standard magnetic and heavy liquid techniques, and then handpicked under a binocular microscope. Zircon yields were only 200 grains in $1.7 \mathrm{~kg}$ from the tuff sample (KY13011903B) and 1,200 grains in $0.3 \mathrm{~kg}$ from the mud flow deposit sample (KY13012102). The separated zircon grains were subhedral with rounded edges and were reddish to pale brown. Randomly selected zircon grains were mounted in a PFA Teflon sheet and polished with several diamond pastes. After chemical etching of spontaneous-fission tracks of ${ }^{238} \mathrm{U}$ on polished surfaces using an $\mathrm{NaOH}-\mathrm{KOH}$ eutectic solution at $225^{\circ} \mathrm{C}$ for 38 hours, we selected zircon grains with relatively lower track density, assuming that they have younger fission-track age. Then, we polished zircon surfaces again prior to $\mathrm{U}-\mathrm{Pb}$ dating analysis to prevent contamination from common $\mathrm{Pb}$.

Zircon $\mathrm{U}-\mathrm{Pb}$ dating was carried out using inductively coupled plasma mass spectrometry (ICP-MS) combined with an ArF Excimer laser-ablation sampling technique (e.g., Hirata and Nisbet, 1995; Iizuka and Hirata, 2004; Sakata et al., 2014) at the Laboratory for Planetary Science, Kyoto University. For laser ablation, a New Wave Research NWR193 laser ablation system (Fremont, CA 94538, USA) was used. Ablation pit sizes were 20 and $25 \mu \mathrm{m}$ in diameter. 
Other operational conditions are as follows: laser wave length $=193 \mathrm{~nm}$, energy density $=2.2-$ $2.3 \mathrm{~J} / \mathrm{cm}^{2}$, crater size $=20 \mu \mathrm{m}$ or $25 \mu \mathrm{m}$, repetition rate $=8 \mathrm{~Hz}$ or $10 \mathrm{~Hz}$, and carrier gas $=$ He. The ICP-MS instrument used in this study was a $\mathrm{Nu}$ Instruments (Wrexham, UK) AttoM high resolution-magnetic sector field-ICPMS (Yokoyama et al., 2011). Operational conditions are: forward power $=1300 \mathrm{~W}$, carrier gas $=\mathrm{Ar}$, gas flow rate $=0.9 \mathrm{~L} \mathrm{~min}^{-1}$ (Ar and He gas), scanning mode $=$ deflector jump, data acquisition protocol $=$ batch, and integration time $=9 \mathrm{~s}$. In order to determine the ${ }^{238} \mathrm{U}_{-}{ }^{206} \mathrm{~Pb}$ and ${ }^{235} \mathrm{U}_{-}{ }^{207} \mathrm{~Pb}$ ages, spot-analyses monitoring ${ }^{202} \mathrm{Hg},{ }^{204} \mathrm{~Pb}\left({ }^{204} \mathrm{Hg}\right)$, ${ }^{206} \mathrm{~Pb},{ }^{207} \mathrm{~Pb},{ }^{232} \mathrm{Th}$, and ${ }^{238} \mathrm{U}$ were performed avoiding inclusions. The instrumental bias for the ${ }^{206} \mathrm{~Pb} /{ }^{238} \mathrm{U}$ ratio was corrected by normalizing the ${ }^{206} \mathrm{~Pb} /{ }^{238} \mathrm{U}$ ratio to 0.1792 using zircon standard 91500 (Wiedenbeck et al., 1995). The OD-3 zircon (ca. 33 Ma; Iwano et al., 2012, 2013) was used as a secondary standard to check the validity of results during each dating session.

\section{Magnetostratigraphy}

Samples for magnetic analysis were obtained from five horizons: the picrobasalt lava (KD4), three mud to very fine sand beds in the fossil-bearing sediment (KD1, KD2, and KD3), and the trachytic pyroclastic flow deposit (KD5). At each site, at least seven oriented samples were collected, and remanent magnetization of the volcanic samples was measured on a spinner magnetometer (Natsuhara SMD-88) and of the sediments using a cryogenic magnetometer (2G Enterprises 755R).

\section{Morphological analysis}

KFS hominin dental materials (two lower dp3s and one upper C) were metrically and morphologically compared with other Plio-Pleistocene hominin taxa, which include Ardipithecus ramidus, Au. anamensis, Au. Afarensis, and Au. africanus. For the ulna (KNM-RK 53525), comparison was made with three other Au. afarensis ulnae and ulnar specimens of later (Pleistocene) ages: Omo L40-19 (hominini indet.), OH 36 (c.f. Paranthropus boisei), and UW88-62 (Au. sediba).

Stable isotopic analysis

One hundred sixteen samples were taken from fossilized mammal tooth enamel for carbon isotope analysis. The samples were removed from fractured enamel surfaces using a dental drill 
with a tungsten carbide bit. Before taking the sample, adhered matrix or dentine was removed from each fracture surface. One to three mg of enamel were collected for each specimen. Carbon isotope ratios of these powdered samples were measured using an isotope ratio mass spectrometer equipped with a GasBench II preparation device (both from Thermo Fisher Scientific) at the Research Institute for Humanity and Nature. Small samples (ca. $0.5 \mathrm{mg}$ ) were weighed with Ag capsules and placed in sample vials. After flushing the vials with Helium gas, phosphoric acid (100\%) was add to the samples and reacted for 24 hours at $25{ }^{\circ} \mathrm{C}$. Then, carbon isotope ratios of evolved $\mathrm{CO}_{2}$ were measured. Isotope ratios were normalized to a working standard that was calibrated against VPDB (Vienna PeeDee Belemnite). The analytical error was within $0.2 \%$. The carbon isotope ratios are expressed by delta-notation as follows: $\delta^{13} \mathrm{C}(\%)=$ $\left(\mathrm{R}_{\text {sample }} / \mathrm{R}_{\text {standard }}-1\right) \times 1000$, where $\mathrm{R}_{\text {sample }}$ and $\mathrm{R}_{\text {standard }}$ is ${ }^{13} \mathrm{C} /{ }^{12} \mathrm{C}$ of sample and standard, respectively.

Isotopic ratios obtained were compared with those published from contemporaneous localities in East Africa (between 3.2 and 3.8 Ma): Koobi Fora (Lokochot Mb), East Turkana (Harris and Cerling, 2002; Harris et al., 2008); Lothagam (Kaiyumung Mb), West Turkana (Uno et al., 2011); Dikika (Sidi Hakoma, Denen Dora, Kada Hadar Mbs), Afar (Bedaso et al., 2013); Laetoli (Upper Laetolil Beds; Kingston, 2011; Kingston and Harrison, 2007). We consider that values < $-8 \%$ indicate a pure $\mathrm{C}_{3}$ diet and values $>-2 \%$ a pure $\mathrm{C}_{4}$ diet, following Uno et al. (2011).

\section{Geology and geochronology}

KFS is located on the margins of the eastern shoulder of the Gregory Rift on the outskirts of Nairobi (01.391 S, 36.724 E, altitude 1746 m; Fig. 1b). The surrounding area is a 1700-1800 m high plateau, that rises to the $\sim 2450 \mathrm{~m}$ Ngong Hills west of the site. The site is named after a small seasonal river known as Kantis ("a fast flowing river" in the Maasai language) that drains the area and flows into the Mbagathi River, finally joining the Athi River. The site is tucked away between two private farms that are separated by the Kantis and was reported to E.M. by one of the farm owners in 2009. Although the presence of the bone bed was noted in the geological survey of Nairobi area (Saggerson, 1991), no systematic research had been conducted in this area prior to 2009. At the time of reporting the site, the farm owner noted that his family first saw fossilized bones on the dry Kantis valley in the mid 70's, but at that time the importance 
of the bones as a paleontological heritage was not appreciated. It was not until the media in Kenya initiated television programs related to paleontological research that local Kenyans began to acquire knowledge on the importance of fossils. As a result, KFS and several sites have since been identified through notifications from the local populace.

Around the site, widely distributed late Cenozoic volcanic rocks associated with minor sedimentary beds unconformably cover a metamorphic basement complex (Saggerson, 1991). Fossils at KFS derive from the base of a thin ( $\sim 30 \mathrm{~m})$, unnamed sequence of sedimentary and volcaniclastic rocks that are stratigraphically sandwiched between the picrobasalt lava, which was previously defined as the Ngong ankaratite and tannbuschite (Saggerson, 1991) and is defined as Kantis basalt in this paper, and the base of the Lower Kerichwa Tuff as mapped in Guth and Wood (2013).

\section{Sedimentary strata at KFS}

The sedimentary succession at the KFS consisting of four units (Level 1, Level 2, Kantis Tuff, and Level 3 beds) lies unconformably above apicrobasalt lava (Kantis Basalt; Fig. 2). The Kantis Basalt is massive and is highly porphyritic with phenocrysts of olivine and abundant clinopyroxene (cpx) in a groundmass of cpx, plagioclase, a small amount of biotite, and titaniferous magnetite. Most of the clinopyroxenes (phenocrysts and groundmass) are titaniferous and aluminous.

The Level 1-3 beds (up to $0.7 \mathrm{~m}$ ) are similar to each other. They are moderately consolidated and consist of poorly sorted, matrix-supported lapilli tuff, containing angular trachyte pebbles and cobbles of lithic fragments (trachyte, pumice, tuff, and basalt; Fig. 3). The gray matrix is homogeneous and consists of trachytic material containing glass shards. The pebbles and cobbles do not show preferred grain fabric except at several locations of the Level 3 bed, where a backset structure (thrust-like structure; Nemec, 1990) was identified. The backset structure shows that the sediment was transported from the west, away from the rift center. The poor-sorting and matrix support suggest that they were deposited from high-viscosity sediment gravity flows (cf. Miall, 1996). The homogeneous tuffaceous matrix is suggestive of deposition by a volcanic mudflow (lahar; cf. Smith and Fritz, 1989) from the west. 
The Kantis Tuff (up to $0.5 \mathrm{~m}$ thick) consists of two parts: gray mud layers with thin sand layers (each $<3 \mathrm{~cm}$ ) and white coarse tuff layers (Fig. 3). The bed is broken into two large blocks in the fossil site and many small cracks are present within it, probably due to minor sliding induced by dragging of the tuff by the Level 3 sediments that were transported by a volcanic mud flow. The tuff bed in the area where the Level 2 bed is thinner than at other locations was probably deposited in a small depression suitable for a small pond. The sand layers are interpreted as being of flood origin from rivers. There are local large footprints in and on top of the tuff (Fig. 3). The latter are interpreted as underprints, which are formed by the impact of feet on layers below the surface on which the animal walked (Lockley, 1991). The presence of footprints and underprints implies that there were habitats for large animals (e.g., hippo, elephant, or rhino) near the locality.

The trachytic pyroclastic flow deposits are poorly sorted massive lapilli tuffs with welded parts, and contain fragments of pumice, trachyte, tuff, and obsidian in a fine- to medium-grained tuffaceous matrix.

Constituent materials of the Kantis Tuff, and the matrix of the lapilli tuffs in the mud flow (lahar) and in the pyroclastic flow deposits are the same: volcanic glass, fragments of anorthoclase, titaniferous and aluminous clinopyroxene, kaersutite, titaniferous magnetite, ilmenite, apatite, and zircon.

Compositions of glass from tuff and matrix of the volcanic mudflow (lahar) deposits are trachytic and are not compositionally distinguishable; mineral compositions are also very similar (Supplementary Online Material [SOM] Table S1). Thus, these pyroclastic materials were supplied from the same source. The matrix of the volcanic mudflow and the pyroclastic flow deposits has trachytic glass and the same mineral assemblage described above, but compositions of the glass and minerals are slightly different.

\section{${ }^{40}$ Ar ${ }^{39}$ Ar ages and glass compositions}

Samples of the Kantis Basalt and the Lower Kerichwa Tuff were collected for ${ }^{40} \mathrm{Ar} /{ }^{39} \mathrm{Ar}$ age determination (SOM Table S2). Using the age of 28.201 Ma for the Fish Canyon Sanidine results in ages that are $\sim 0.36 \%$ older than those used in recent compilations of ages at other sites, for 
which an age of 28.10 Ma was employed (Brown et al., 2013). The lava from the stream underlying the fossil site yielded $\mathrm{a}^{40} \mathrm{Ar} /{ }^{39} \mathrm{Ar}$ weighted plateau age of $5.30 \pm 0.02 \mathrm{Ma}$, and ages derived from normal and inverse isochron ages of 5.28 $\pm 0.05 \mathrm{Ma}$. A clast from the fossiliferous level that is petrographically very similar yielded indistinguishable results: ${ }^{40} \mathrm{Ar} /{ }^{39} \mathrm{Ar}$ weighted plateau isochron age of $5.30 \pm 0.01 \mathrm{Ma}$, and normal and inverse isochron ages of 5.28 $\pm 0.02 \mathrm{Ma}$. Errors stated are two standard deviations. An age of $2.77 \pm 0.01 \mathrm{Ma}$ was obtained on the Lower Kerichwa Tuff that lies $\sim 25 \mathrm{~m}$ stratigraphically above the level of KFS. Poorly exposed strata between KFS and the Lower Kerichwa Tuff contain at least one very tuffaceous sandstone about $15 \mathrm{~m}$ above KFS.

Compositions of glass from the Kantis Tuff (K09-618B), a tuff in the overlying sequence (K09-619), and the Lower Kerichwa Tuff (K09-686) were determined by electron microprobe using methods described in Nash (1992). All are trachytes with rather high $\mathrm{TiO}_{2}$ and $\mathrm{CaO}$ contents (SOM Table S3). Feldspar from the Lower Kerichwa Tuff has a composition $\mathrm{An}_{2} \mathrm{Ab}_{62} \mathrm{Or}_{36}$, near the boundary between anorthoclase and soda-sanidine.

\section{Zircon $\mathrm{U}-\mathrm{Pb}$ ages}

Samples for zircon U-Pb age determination were taken from the trachytic tuff and the mudflow (KY13011903B and KY13012102, respectively) in the fossiliferous Level 2 (SOM Table S4). Uncertainties of isotopic ratios and $\mathrm{U}-\mathrm{Pb}$ ages are two standard deviations. The zircon grains were divided into four groups in terms of ages; Neoarchean (2629.9 $\pm 167.5 \mathrm{Ma})$, Neoproterozoic (600 700 Ma), Miocene (6 7 Ma), and Pliocene (3 4 Ma). The Neoarchean zircon was probably derived from basement rocks of the Tanzania Craton. The Neoproterozoic and Miocene zircon grains were most likely derived from the pan-African orogenic Mozambique belt and rift volcanic rocks, respectively.

Concordia diagrams for the youngest grain were plotted (Fig. 4) and the weighted mean ${ }^{238} \mathrm{U}_{-}$ ${ }^{206} \mathrm{~Pb}$ ages for concordant data calculated using the Isoplot 3.6 program (Ludwig, 2008). Since the trends of discordant data for both samples are probably explained by common $\mathrm{Pb}$ contamination, the youngest grains were dealt with as single age population. The lower intercept ages of $3.3 \pm 0.3 \mathrm{Ma}$ for KY13011903B and 3.6 $\pm 0.2 \mathrm{Ma}$ for KY13012102 were concordant with each other (Fig. 4). Calculated weighted mean ages using only the concordant ${ }^{238} \mathrm{U}_{-}{ }^{206} \mathrm{~Pb}$ are 
$3.4 \pm 0.1 \mathrm{Ma}$ (5 spots) for KY13011903B and 3.5 $\pm 0.2 \mathrm{Ma}$ (8 spots) for KY13012102 and have higher precision (Fig. 4).

\section{Magnetostratigraphy.}

Samples for magnetic analysis were obtained from five horizons (Fig. 2): the picrobasaltlava (KD4), three mud to very fine sand beds in the fossil-bearing sediment (KD1, KD2, and KD3), and the trachytic pyroclastic flow deposit (KD5). Results of alternating field (AF) and thermal demagnetization showed that all samples had a characteristic component almost linearly decaying toward the origin between 10 to $70 \mathrm{mT}$, or 300 and $600{ }^{\circ} \mathrm{C}$ (Fig. 5a). The characteristic magnetic directions determined by principal component analysis are well concentrated near the geomagnetic field direction expected from the geocentric axial dipole model, with normal

polarity except for one result from a block sample of the trachytic pyroclastic flow deposit (KD5) showing an anomalous direction (Declination $=278^{\circ}$; Inclination $=34^{\circ}$; Fig. 5b). We interpret that this fragment might have been rotated after cooling below the blocking temperature, and thus does not record the geomagnetic field at the time of deposition. Thus, the five horizons constitute a single normal polarity interval. Given the U-Pb ages of zircon (3.4 $\pm 0.1 \mathrm{Ma}$ and 3.5 $\pm 0.2 \mathrm{Ma}$ ) and the normal polarity of the strata, the normal polarity zone can be assigned to the Gauss Normal Chron, and most likely to C2An.3n (3.330-3.596 Ma; Ogg, 2012). An age of 3.45 Ma for the fossil bed is consistent with the age $(2.77 \pm 0.01 \mathrm{Ma})$ of feldspar from the Lower Kerichwa Tuff that lies about $25 \mathrm{~m}$ higher in the section. Table 1 summarizes the radiometric ages and magnetostratigraphy of the Kantis Basalt, fossiliferous beds, and Lower Kerichwa Tuff at KFS.

\section{Hominin fossils}

Over the last four years of research, 1,200 fossil elements have been collected from KFS. About 740 identifiable faunal specimens comprise 29 taxa including one hominin species (Table 2). The hominin dental sample consists of two left lower dp3s (KNM-RK 53000 andKNM-RK 53001) and a left upper canine (KNM-RK 57800) representing two juveniles and one adult.

KNM-RK 53001 is a left lower dp3 crown (Fig. 6a) that measures $8.7 \mathrm{~mm}$ mesiodistally and $6.9 \mathrm{~mm}$ buccolingually. The maximum oblique diameter is $9.3 \mathrm{~mm}$. The occlusal outline of the 
crown is an asymmetric ovoid, with the mesiobuccal portion protruding slightly. The buccal portion of its distal surface is broken, missing a small chip of enamel, but the lingual portion is preserved, and shows part of the distal interstitial wear facet. On the other hand, there is no mesial interstitial wear facet. The crown is moderately worn, exposing a small area of dentine on the protoconid, a tiny area of dentine on the metaconid, and a large area of dentine on the hypoconid. The protoconid is the largest and highest cusp.

The short preprotocristid runs down mesially to meet with the wide mesiolingual cingulum. This cingulum slightly runs down distolingually to end at the base of the metaconid. The mesial fovea defined by the preprotocristid, premetacristid, and mesiolingual marginal ridge faces mesiolingually. The lingual slope of the protoconid is inflated, restricting the mesial fovea. The metaconid is well-developed, but it is much smaller and slightly lower than the protoconid. The metaconid is positioned close to and distolingual to the protoconid. These two cusps are linked to each other by a short and oblique crest. The postprotocristid runs down distally to meet with the hypoconid. A very short groove runs down on the buccal surface from the base of the postprotocristid, and ends at a small but distinct pit. The hypoconid is the second largest cusp, but it is much lower than the protoconid and metaconid. The hypoconid is much more heavily worn than the other cusps. The entoconid is a small low cusp at the distolingual corner of the crown. It shows a weak wear facet. There may be another small cusplet on the distal margin of the crown between the entoconid and hypoconid, corresponding to the hypoconulid, though damage to the distal margin and occlusal wear have obscured the morphology of this area.

KNM-RK 53000 is another left lower dp3 crown (Fig. 6a). It measures $8.6 \mathrm{~mm}$ mesiodistally and $7.1 \mathrm{~mm}$ buccolingually. The maximum oblique diameter is $9.4 \mathrm{~mm}$. The preservation is not as good as that of KNM-RK 53001, lacking a large chip of enamel from the distobuccal corner of the crown, but the tooth is less worn. Only the protoconid shows a small island of dentine exposure. The morphology of the preserved portion of the crown is similar to that of KNM-RK 53001. The mesial fovea is distinct and the metaconid is well-developed. The buccal groove separates the protoconid and the broken hypoconid. The entoconid is well differentiated.

Leakey et al. (1998) described a lower dp3 of Au. anamensis (KNM-KP 34725) from Kanapoi as intermediate between Ardipithecus ramidus and Au. afarensis. The Au. anamensis specimen is 
more primitive than $A u$. afarensis in having a narrower crown, which lacks the buccal and lingual grooves so that the talonid is poorly differentiated (Leakey et al., 1998). On the other hand, the dp3s of Au.afarensis have a broader crown with a buccolingually expanded talonid, where the distal cusps are better differentiated, as well as a marked mesial fovea and welldeveloped metaconid (White et al., 1994). In these features, the Kantis lower dp3s are different from $\mathrm{Au}$. anamensis and resemble those of Au. afarensis (Table 3, Fig. 6b). In the lower dp3 of Au. africanus (Taung Child), the talonid is more expanded buccolingually than in the Kantis specimens.

KNM-RK 57800 is a left upper canine with most of the root preserved (Fig. 6c). The crown is slightly worn at the apex and along the mesial and distal crests. A tiny area of dentine is exposed at the apex. The preserved buccal height measures $14.9 \mathrm{~mm}$. The crown is as broad as it is long, as the root is bucally rotated. The mesial shoulder of the crown is positioned high. In buccal view, the mesial shoulder is located at about two thirds of the buccal crown height from the cervix. The distal shoulder is also high-positioned, being at half of the buccal crown height. The mesial and distal buccal grooves are obscure, being just faint depressions. The mesial and distal crests are thick and rounded. In lingual view, the mesial groove is deeply incised near the base of the mesial crest, but it does not extend much towards the apex. The lingual cingulum is restricted to the mesial and distal ends of the lingual aspect. There is a low basal swelling, from which a low and coarsely crenulated lingual pillar descends apically. The lingual surface distal to the lingual pillar is concave. The mesial style is poorly developed, while the distal style is better developed. Both of them, however, are unlike the prominently developed styles observed in the upper canine of $\mathrm{Au}$. anamensis (KNM-KP 35893). The root is ca. $25 \mathrm{~mm}$ long with a number of cracks. Its cross section is a rounded triangle, with the mesiolingual, buccal, and distal surfaces. The mesiolingual and distal surfaces of the root are rather flat, though a wide shallow vertical groove is developed on the former. The buccal surface of the root is rounded, being convex mesiodistally and cervicoapically. The Kantis upper canine is distinguished from that of $A u$. anamensis in its high position of the mesial and distal shoulders, shorter mesial and distal crests, better developed lingual pillar, and much weaker development of the styles and buccal grooves (Fig. 6d). In these aspects, KNM-RK 57800 is more similar to canines of Au. afarensis. 
Upper canine morphology of Kenyanthropus platyops is largely unknown. Although an upper canine in a maxillary fragment (KNM-WT 38343) has been discovered from Lomekwi in the Turkana Basin (Leakey et al., 2001), which is contemporaneous with Kantis, the Lomekwi canine is severely damaged. The distal half of the crown is broken off, and the remaining mesial portion is separated into buccal and lingual fragments by a wide mesiodistal crack in occlusal view. In their original description, Leakey et al. (2001) noted that this canine "seems lowcrowned when compared with $A$. afarensis canines of similar size and degree of wear" without providing measurements. We think that estimation of crown height is difficult given the effects of occlusal wear and individual variation. What we can say is that the mesial shoulder of the crown of KNM-WT 38343 appears relatively high-positioned as in Au. afarensis. KNM-RK 57800 may be similar to the upper canine of $K$. platyops, but this limited "similarity" neither provides sufficient evidence to assign KNM-RK 57800 to $K$. platyops, nor eclipses the greater similarity to $\mathrm{Au}$. afarensis canines.

KNM-RK 53525 is a proximal half portion of a left ulna of a large primate (Fig. 6e). The maximum length is $151 \mathrm{~mm}$. The presence of the median trochlear keel, wide trochlear articular surface, low olecranon process, and anteroposteriorly flattened middle part of the shaft indicate that it is of a hominin, not of a large-sized cercopithecid (see below). Fusion of the olecranon epiphysis, development of muscles' attachment marks, and overall size suggest that this bone belongs to an adult male (Fig. 7). The proximal olecranon surface is widely eroded preserving only a small area (ca. $10 \mathrm{~mm}$ anteroposteriorly and $6 \mathrm{~mm}$ mediolaterally). This intact surface approximates the original, most proximal part of the olecranon. The medial and posterior surfaces of the olecranon are eroded. Borders of the articular surface of the trochlear notch are almost entirely eroded, except the lateral border and both tips of the olecranon and anconeal processes are lost.

Due to preservation, many standard osteometric measurements cannot be obtained on KNMRK 53525. However, some measurements, including the minimally estimated ones, show that KNM-RK 53525 is most comparable to the male Au. afarensis ulna A.L. 438-1 from Hadar (Drapeau et al., 2005) in size (Table 4). 
The trochlear notch surface is only gently keeled (= crested). Proximal and distal keeling angles (Drapeau et al., 2005) are $136^{\circ}$ and $134^{\circ}$, respectively, and slightly more blunt than in other Au. afarensis individuals (SOM Table S4). Because of the damage on the anconeal and coronoid processes, olecranon orientation and trochlear notch orientation (Drapeau et al., 2005; Haile-Selassie et al., 2010) could not be evaluated. The radial notch measures $>14.5 \mathrm{~mm}$ anteroposteriorly and $>10.7 \mathrm{~mm}$ proximodistally (minimum estimates because of border erosion), and it is set at about $20^{\circ}$ to the anteroposterior axis of the trochlear joint in top view.

Proximal diaphyseal morphology of KNM-RK 53525 closely resembles that of A.L. 438-1a (Figs. 6e and 7; also see Drapeau et al., 2005). The supinator crest, which starts from the posterior border of the radial notch, is strongly developed. The distal extension of the supinator crest becomes a blunt but distinct ridge that descends obliquely (posterodistally) to form the posterior ridge. The lateral surface delineated by this oblique/posterior ridge and the interosseous crest is wide and flat. Distal to the coronoid process, the anterior border appears as an acute ridge about $4 \mathrm{~cm}$ long, then becomes indistinct as a concave surface. Lateral to this acute ridge is a deep groove for the insertion of the brachialis muscle. The medial border of this area is a sharp and distinct ridge, which probably originally continued upward to the anteromedial border of the coronoid process. Posterior to this ridge, at about the level of the coronoid process, is a deep hollowed area for the origins of the flexor digitrum superficialis and pronator teres muscles. In A.L. 288-1, corresponding surface features can be defined. However, they differ in either shape or position. The supinator crest is more anteriorly positioned, less distinct, and much less salient laterally. The area delineated by the oblique/posterior ridge and interosseous crest is narrower and convex. The brachialis insertion is distinct but wider and shallower. The insertion area of the flexor digitrum superficialis and pronator teres muscles is merely a shallow concavity. We think that these differences are essentially related differences of body size and upper limb muscularity.

Anteroposterior curvature of the diaphysis of KNM-RK 53525 is moderately developed like that of A.L. 438-1a (Fig. 7). Although the entire bone is necessary for rigorous quantification of ulnar curvature, curvature of KNM-RK 53525 is more pronounced than in the corresponding portion of A.L. 288-1, UW-88-62, and Omo L40-19, and less so than in OH 36. Although whole shaft curvature of Omo L40-19 is nearly comparable to that of OH 36 (Drapeau et al., 2005), it is proportionally long and markedly curved in the middle-to-distal portion. Omo L40-19 is distinct 
from all the other ulnae in the anteroposteriorly, extremely flattened proximal shaft (McHenry et al., 1976). In $\mathrm{OH} 36$, the insertion area of the brachialis is more proximally positioned. The anterior ridge ascending to the beak of the coronoid is absent, although the medial ridge that delineates the brachialis insertion medially is present.

In summary, KNM-RK 53525 resembles A.L. 438-1a in both size and shape more than it does any other fossil hominin ulnae compared here. It is possible that this ulna and the upper canine KNM-RK 57800 derived from the same individual since they were excavated $30 \mathrm{~cm}$ apart on the same horizon (Level 2 bed). However, this possibility is not strongly supported given that two left lower dp3s have been recovered from the site.

Based on themorphological details described above, we assign the Kantis hominin to $A u$. afarensis. The age of the fossiliferous deposits at KFS (3.6-3.3 Ma) is consistent with this interpretation.

\section{Faunal assemblage}

Of the 1,200 fossil elements from KFS, 740 identifiable faunal specimens are assigned to 29 taxa (Table 2). Hippopotamids were dominant among large mammals $(N=311,42 \%$ of the NISP). They are followed by bovids $(N=183,25 \%)$, cercopithecids $(N=73,13 \%)$, suids $(N=$ $67,9 \%)$, equids $(N=39,5 \%)$, rhinocerotids $(N=38,5 \%)$, giraffids $(N=13,1.8 \%)$, elephantids $(N=6,0.8 \%)$, carnivora $(N=5,0.7 \%)$, and hominins $(N=4,0.5 \%)$.

\section{Hippopotamidae}

The KFS hippopotamids belong to at least two different species. An unidentified species is represented by a single upper second molar that is distinguished from other Kantis material by its very large size. The rest of the collection is mostly attributable to the hippopotamid lineage that is found in the Turkana Basin during the Pliocene. This material displays features intermediate between the taxon found at Kanapoi and Allia Bay (aff. Hippopotamus cf. protamphibius: 4.24.1 Ma; Harris et al., 2003; Weston, 2003) and that found in the lower levels of the Omo Group formations (equivalent to Member B of the Shungura Formation: 3.4-2.9 Ma: aff. Hippopotamus protamphibius turkanensis; Gèze, 1985). The overall size of craniodental remains is comparable to that of the Kanapoi material (i.e., somewhat larger than the later Turkana material), displaying 
a robust mandible, moderately expanded canine apophyses, and three well-developed incisors. However, the lower i3 is slightly more reduced compared to the il than is the case for the Kanapoi hippos. The cranium displays elevated orbits and sagittal crests that are more similar in elevation to those from lower Shungura or Koobi Fora than those at Kanapoi. The premolar row is somewhat more reduced than in the Kanapoi material, and upper P4s display morphologies reminiscent of the variability observed in later Turkana material. Therefore, for the time being, we keep the name aff. Hippopotamus cf. protamphibius for the material attributable to this lineage (see also Boisserie, 2005). The on-going revision of the Omo material, in addition to this new material from KFS, should lead to a more precise definition in the near future. Most of the postcranial elements are probably related to aff. Hippopotamus cf. protamphibius.

\section{Suidae}

Notochoerus euilus is abundant and is by far the most common suid species. Complete m3s have four pairs of pillars and a tricuspidate talonid; large upper canines much resemble those of specimens from the lower part of the Koobi Fora Formation. Neither Nyanzachoerus kanamensis nor Kolpochoerus afarensis, which are common in other contemporaneous Rift Valley localities together with N. euilus (Bishop, 2010), have been definitely recognized, although a smaller suid (Kolpochoerus?) is probably represented by tooth fragments.

\section{Giraffidae}

Sivatherium sp. is definitely identifiable by dental remains, none of which can be unambiguously referred to Giraffa.

\section{Bovidae}

The bovids include representatives of the tribes Alcelaphini, Hippotragini, Reduncini, Aepycerotini, Cephalophini, Bovini, Antilopini, and Tragelaphini. Alcelaphini, Aepyceros sp., and Bovini are dominant while Tragelaphini, Reduncini, and Cephalophini are quite rare. Even though sample size is small, the difference in faunal relative abundances is so marked that it is unlikely to change significantly with further collecting, compared to contemporary localities within the Rift Valley. 
Two species of Alcelaphini are present: a large Damaliscus sp. and a diminutive indeterminate species. Large alcelaphin horn-cores (KNM-RK 51259, 53786, 57389) are more regularly and strongly spiraled than those of most alcelaphins, except some early Pleistocene Damaliscus (D. agelaius from Olduvai [Gentry and Gentry, 1978] and D. strepsiceras from Garba IV at Melka Kunturé [Geraads et al., 2004]). It also resembles Parmularius pandatus from Laetoli (Gentry, 1987, 2011) but, unlike KNM-RK 51259, P. pandatus has the long pedicel and posterior basal swelling typical of its genus. Therefore, we leave these specimens as cf. Damaliscus sp. nov. Dental remains indicate the presence of another, diminutive alcelaphin species (Alcelaphini gen. et sp. indet.), similar in size to an unidentified species from the Kada Hadar Member at Hadar (Geraads et al., 2012), or to P. parvicornis from the Upper Ndolanya beds at Laetoli (Gentry, 2011).

The only recognized hippotragin is close to Oryx deturi from Laetoli (Gentry, 2011) and Hadar (Geraads et al., 2012), characterized by the transverse compression of its horn-cores (instead of antero-posterior in modern forms). Several hippotragin teeth probably belong here as well. A single upper molar attests to the presence of Reduncini (Kobus sp.). Two horn-cores resemble those of the Laetoli impala (Aepycerotini) in their large size, transverse ridges, and curvature in lateral view, but are longer and almost straight in frontal view. They can be called Aepyceros aff. dietrichi (Gentry, 2011) but probably represent a new species, adding to the already great diversity of Plio-Pleistocene impalas.

Two upper molars have strong, rounded labial ribs but no mesostyle; these features best match those of the duikers (Cephalophus sp.: Cephalophini). A bovin metacarpal matches in size a metatarsal from Amado in the Woranso-Mille region (Geraads et al., 2009) and is tentatively attributed to Ugandax sp. A few teeth belong to an antilopin identifiable as Gazella. Tragelaphins are uncommon; one mandibular fragment definitely belongs to a large representative of this tribe, and a few teeth probably belong here as well.

\section{Equidae}

Equids are represented only by isolated teeth, preventing assignment to species. We keep the name Hipparion (s.1.) sp. for the KFS material, because the sole synapomorphy of 
"Eurygnathohippus," presence of ectostylids (Eisenmann and Geraads, 2007), is absent in several KFS lower cheek teeth. There is no evidence of Equus.

\section{Rhinocerotidae}

Almost all rhino fossils are of Ceratotherium mauritanicum. Several specimens display a distinctly less derived tooth pattern than the modern "white" rhino (Geraads, 2005). A few teeth definitely belong to Diceros, but this genus is much less common.

\section{Carnivora}

A lower p4 (KNM-RK50508) with narrow tall cuspids displays the typical morphology of saber-toothed felids and is attributable to Homotherium. However, species identification will require revision of African members of this group. A left $\mathrm{m} 2$ was identified by L. Werdelin (pers. comm.) as Enhydriodon. An upper carnassial fragment belongs to Crocuta. The Herpestidae are represented by a $\mathrm{P} 4$ and a $\mathrm{ml}$ that must be referred to two different genera.

\section{Elephantidae}

This family is represented by tooth fragments only.

\section{Cercopithecidae}

Most cercopithecid fossils belong to Papionini and they are attributable to a single taxon with large sexual dimorphism. The KFS papionin is distinct from Theropithecus and Parapapio, known from contemporaneous Turkana Basin sites (Jablonski and Leakey, 2008). The KFS papionin material is mainly comprised of isolated teeth, but it also includes a well-preserved cranium and a mandibular fragment. The KFS papionin lacks a deep fossa on the mandibular corpus, as well as the maxillary fossa and ridge in contrast to most papionins, and is similar in these features to Parapapio and Pliopapio (Jablonski and Leakey, 2008). The skull from KFS, however, shows a distinct anteorbital drop around the nasal region. This feature does not fit the facial morphology of Parapapio, where the nasal profile is relatively straight without a prominent anteorbital drop. The anteorbital drop is more or less developed in papionins other than Parapapio. Although molars of the Kantis papionin have cusps that are slightly compressed mesiodistally, they remain in a more primitive papionin condition compared to the specialized 
molar morphology observed in Theropitheus, where the molar cusps are strongly pinched and usually higher, and the molar cingula are much better developed. The KFS papionin also differs from Papio, as it lacks a deep maxillary fossa, distinct maxillary ridges, as well as a deep mandibular fossa, and it has a relatively shorter muzzle. The KFS papionin is, therefore, left as Papionini indet.

Although represented by only a few isolated teeth and possibly an ulnar fragment, a large colobine is present, as is also the case in the primate communities of contemporaneous Turkana Basin sites and Laetoli (Jablonski and Leakey, 2008). Two upper molars (KNM-RK 55044 and KNM-RK 55512) are similar in size to the other KFS upper molars assigned to Papionini indet., but are distinguished from the latter in having higher and less inflated cusps, sharp occlusal crests, a much more reduced mesial lingual cleft, and lacking the parastyle and mesial buccal cleft. These specimens very likely belong to a large colobine species.

\section{Biochronology}

Biochronological conclusions from the large mammal fauna are not straightforward, probably because the KFS fauna, in the Kenyan highlands, does not easily correlate with lowland faunas; in particular, the bovid taxa that are potentially most useful, cf. Damaliscus and Aepyceros, do not look identical with previously named forms. Of course the absence of Equus implies an age greater than 2.3 Ma; the morphology of the Oryx horn-cores and the presence of Notochoerus euilus confirm this, but do not add precision. Thus, the large mammal fauna is in agreement with a ca. 3.4-3.5 Ma age, though it does not firmly support it.

\section{Paleoecology}

The dominance of Oryx and alcelaphins, together with the virtual absence of reduncins and tragelaphins among bovids, unambiguously point towards an open landscape, confirmed by the dominance of Ceratotherium among rhinos and a virtual absence of brachyodont suids and of the browsing Giraffa. The single specimen of Cephalophus, whose modern representatives are forest-dwellers, seems to go against this but, as noted in Gentry (2011), they may in fact have secondarily returned to close environments, and their close relative Sylvicapra is found in open landscapes. 
In order to compare the faunal assemblage of KFS with those of other East African sites of similar ages more objectively, we performed two factor analyses. The first one (Fig. 8) uses the number of species in each locomotor and dietary category as columns and modern localities as rows (data from Reed, 1998), fossil sites being added a posteriori (illustrative). It shows that the point cloud of fossil sites covers only part of the modern one, implying that the fossil assemblages do not greatly differ from each other. In addition, the clouds only partly overlap, as if the fossil cloud was shifted in relation to the modern one (this issue is discussed in detail by $\mathrm{Su}$ and Harrison, 2007). This is probably because of taphonomic bias, but it forbids interpreting fossil assemblages similar to modern localities that are close on the graph (as was done, e.g., by DiMaggio et al., 2015). Among fossil sites, Kantis plots near Hadar and the Lower Lomekwi, and is farther from the Upper Laetolil Beds, but occupies a marginal position.

The second analysis (Fig. 9) was performed on fossil assemblages and a number of specimens in the various bovid tribes (the rare Cephalophini and Brabovus being illustrative). It clearly separates the Laetoli sites with high numbers of open-country antelopes from those with greater wood cover (lower right) or more grasslands (upper right). Again, Kantis occupies a marginal position with respect to contemporaneous Ethiopian and Northern Kenyan sites, but is closer to Laetoli because of its higher content of open-country forms.

Keeping in mind that these graphs should be interpreted with caution, because they represent only the plane of the first two axes, and because of taphonomic biases, we can conclude that the Kantis site samples a mammalian assemblage that, although generally similar to those of contemporaneous sites, differs from all of them, thus broadening the range of environments inhabited by $A u$. afarensis.

\section{Stable carbon isotope}

Stable carbon isotope ratios obtained from fossil mammal tooth enamel can be used to infer the proportion of consumption of $\mathrm{C}_{3}$ and $\mathrm{C}_{4}$ food resources (Cerling et al., 2003). To reconstruct the paleoenvironment at KFS, we sampled tooth enamel from seven mammalian families (Table 5; Fig. 10). The average $\delta^{13} \mathrm{C}$ value of fossil tooth enamel from Kantis $(-3.0 \pm 2.9 \%$ ) is similar to values known from other $A$ u. afarensis sites but significantly higher than that for mammals from Laetoli (Fig. 10; ANOVA: $F=14.5, p<0.01$ ). The average $\delta^{13} \mathrm{C}$ value for the hippopotamid (aff. 
Hippopotamus cf. protamphibius $)$ is $-2.2 \pm 1.7 \% 0(N=30)$, indicating a mixed $\mathrm{C}_{3} / \mathrm{C}_{4}$ to $\mathrm{C}_{4-}$ dominated diet. This value is significantly higher than that of hippopotamids from the Turkana Basin and Dikika $(F=6.3, p<0.01)$, and quite comparable to values obtained for extant Hippopotamus amphibius (Boisserie et al., 2011). $\delta^{13} \mathrm{C}$ values of bovids do not differ from those of Lothagam, Dikika, and Laetoli, although Dikika bovids have higher $\delta^{13} \mathrm{C}$ values than Laetoli bovids (ANOVA: $F=7.9, p<0.01$ ). Of the 13 bovid specimens, seven are alcelaphins (SOM Table S5). The average $\delta^{13} \mathrm{C}$ value of KFS alcelaphins is $-4.3 \pm 3.2 \%$ and compares well with the extant hartebeests (Alcelaphusspp.; Cerling et al., 2003) and with alcelaphins of Dikika and Laetoli (SOM Table S5). The $\delta^{13} \mathrm{C}$ value of Notochoeruseuilus from this site is $-0.9 \pm 0.6 \%$ o $(N=$ 22), indicating $\mathrm{C}_{4}$-dominated diets similar to those of $N$. euilusfrom other localities. Although the KFS average is slightly higher than the others, there is no statistical difference (ANOVA: $F=2.1$, $p=0.08$ ). The variation in $\delta^{13} \mathrm{C}$ of the KFS sample is small compared to other localities (Bartletttest: $F=7.5, p<0.01$ ). The value for the two rhinocerotid species (Ceratotherium mauritanicum $[N=25]$ and Diceros sp. $[N=1])$ is $-5.2 \pm 1.2 \%$, showing a mixed $\mathrm{C}_{3} / \mathrm{C}_{4}$ signature like those in Laetoli and Dikika, while Lothagam $(N=3)$ shows a pure $\mathrm{C}_{4}$ signal. Equids, giraffes, and elephantids also have $\delta^{13} \mathrm{C}$ values similar to those of the respective taxa from other localities.

\section{Discussion}

Australopithecus afarensis was previously known from northern Ethiopia to northern Tanzania, a latitudinal spread from $11^{\circ} \mathrm{N}$ to $3^{\circ} \mathrm{S}(>1500 \mathrm{~km})$. The presence of Au.afarensis in the Turkana basin of Kenya is contested (Kimbel 1988; Ward et al., 1999; Brown et al., 2001; Kimbel and Delezene, 2009; Wood and Leakey, 2011). The KFS hominin specimens are the first clear evidence of this species in Kenya. In addition, KFS is unique in Kenya in its location on the eastern shoulder of the Gregory Rift Valley, hence expanding the Au. afarensis range east of the Rift Valley.

In spite of differences at low taxonomic levels, the KFS fauna is generally similar to that known from contemporaneous sites within the Rift Valley. Dental enamel isotopic signals of the KFS mammals compare well to those documented in the same or related taxa from contemporaneous localities. This may suggest that similar environments (various mosaics of woodland, shrubland, and grassland) were present in this area $3.5 \mathrm{Ma}$. 
However, KFS was likely more open compared to the localities within the Rift Valley. Unlike these localities, the KFS suid assemblage virtually lacks brachyodont species. The bovid samples are dominated by alcelaphins, Aepyceros, and Oryx, whereas tragelaphins and reduncins are rare. Browsing tragelaphins occur in high frequency in localities within the Rift Valley, such as Woranso-Mille in Ethiopia (Geraads et al., 2009), the Sidi Hakoma Member at Hadar (Geraads et al., 2012), and the Omo-Turkana basin in Kenya and Ethiopia (Gentry, 1985; Harris, 1991). In addition, hippopotamid dental enamel yielded relatively high $\delta^{13} \mathrm{C}$ values. Considering the semiaquatic habits of the group, this suggests that vegetation surrounding water bodies at KFS was probably richer in $\mathrm{C}_{4}$ plants than was the case at other sites of similar age. Hippopotamid remains are represented by several individuals of different biological age (including young specimens) and Enhydriodon sp. is present, which is strong evidence for perennial water bodies of metric to plurimetric depth at KFS. Taken together, these results suggest that a grasslanddominated (less wooded) environment, like the present Nairobi National Park habitats, was present in this area around 3.5 Ma. Cerling et al. (2011) suggested that woody cover was $\sim 40-$ $60 \%$ at fossil sites in the Omo-Turkana Basin and Awash Valley around 3.6 Ma, so a smaller fraction of woody cover may pertain at KFS.

Laetoli (Upper Laetoli Beds: ULB), which is located on the 1,700-1,800 m high Eyasi Plateau, is the only other Pliocene locality with a comparably high elevation, but it is located west of the Gregory Rift Valley. The KFS and Laetoli are markedly different in the paleoenvironment and fauna. The ULB are unique in having no evidence for an extensive body of water in the depositional area, although gullies and minor channels are relatively common (Ditchfield and Harrison, 2011). Streams and rivers were probably seasonal in the ULB and the landscape was much drier compared to the KFS. The mammalian faunal composition differs greatly between the KFS and ULB. A main difference is that no hippopotamid fossil has been collected from the ULB, where the dominant taxa are leporids, bovids, rodents, and giraffids ( $>6 \%$ of the NISP; Harrison, 2011). Notably, the relative abundance of cercopithecid fossils is much higher in the KFS than in the ULB (9.9\% vs. $0.9 \%$ relative to the NISP or $39.9 \%$ vs. $2.6 \%$ relative to the number of identified bovid specimens). In the ULB, the semi-terrestrial Parapapio ado comprises two-thirds of the cercopithecid specimens and an arboreal colobin (cf.

Rhinocolobus sp.) makes up most of the rest. Among the KFS cercopithecid remains, a new 
unnamed papionin is predominant and colobinae fossils are very rare, suggesting that the KFS was not suitable for arboreal monkeys. Bovid assemblages of KFS and ULB differ less than those of other groups. Alcelaphini and Hippotragini are dominant bovids, whereas Reduncini and Tragelaphini are rare or absent (Gentry, 2011). The (near) absence of these tribes contrasts with other contemporaneous localities. On the other hand, Neotragini (overwhelmingly Madoqua, dik-diks), which is a prominent tribe along with Alcelaphini in the ULB bovid assemblage (Gentry, 2011; Su, 2011), are absent at KFS. Neotragines are also rare or absent in most East African Pliocene sites, but taphonomy and/or collecting procedures certainly partly explain this difference. In summary, the faunal characteristics of these highland localities are rather varied and suggest different environmental settings. Kantis was probably more mesic with less wood cover. The presence of $A u$. afarensis in both sites, therefore, endorses a greater tolerance of this hominin species for varying habitats. Perhaps this environment variability foreshadows the greater adaptability of early Homo, which probably appeared ca. 2.8 Ma. At that time, environments probably ranged from grassland (Upper Lomekwi, Fig. 9) to bush (Shungura C; Fig. 9) and open savannah (DiMaggio et al., 2015).

While the presence of Au. afarensis was well documented in Ethiopia and Tanzania, the evidence in Kenya was not clear. The occurrence of the species at KFS provides an intermediate point on the distribution of species between Ethiopia and Tanzania. The discovery of $A u$. bahrelghazali from the Chad Basin (Koro Toro) extended the habitat of Australopithecus westward from the Rift Valley (Fig. 1a; Brunet et al., 1995). Likewise, the presence of $A u$. afarensis at KFS indicates that the Pliocene hominins' range had spread eastward across the Rift margin and possibly further than that. For example, it cannot be precluded that the range of $A u$. afarensis expanded eastward from the present Nairobi area to the ancient Athi River channels and its plains. Although the Gregory Rift Valley has been the focus of paleoanthropologists' attention in East Africa for many years, surveys of the Rift shoulder may open a new perspective for African mammal and hominin evolution during the Pliocene.

\section{Acknowledgments}

We gratefully acknowledge financial support for this project from the Leakey Foundation, JSPS-NACOSTI, WennerGren Foundation, Paleontological Scientific Trust (PAST), the F. H. 
Brown Rosenblatt Fund (University of Utah), and the National Museums of Kenya (NMK). Stable isotopic analysis was supported by Joint Research Grant for the Environmental Isotope Study of Research Institute for Humanity and Nature. We also owe our gratitude to the following people for advice on various aspects of this study: Bill Kimbel, Carol Ward, Stephen Frost, Lars Wedelin, Fred Spoor, Fredrick K. Manthi, H. Nakaya, NMK Field Crew at KFS, Stephen Kesuke, Francis LemayianKesuke, Simon Gatheru, and Dorothy Syanda. 


\section{References}

Aiello, L.C., Wood, B., Key, C., Lewis, M., 1999. Morphological and taxonomic affinities of the Olduvai ulna (OH 36). Am. J. Phys.Anthropol. 109, 89-110.

Alemseged, Z., Wynn, J.G., Kimbel, W.H., Reed, D., Geraads, D., Bobe, R., 2005. A new hominin from the basal member of the Hadar Formation, Dikika, Ethiopia, and its geological context. J. Hum. Evol. 49, 499-514.

Bedaso, Z.K., Wynn, J.G., Alemseged, Z., Geraads, D., 2013. Dietary and paleoenvironmental reconstruction using stable isotopes of herbivore tooth enamel from middle Pliocene Dikika, Ethiopia: Implication for Australopithecus afarensis habitat and food resources. J. Hum. Evol. 64, 21-38.

Bishop, L.C., 2010. Suoidea. In: Werdelin, L., Sanders, W.J. (Eds.), Cenozoic Mammals of Africa. University of California Press, Berkeley, pp. 821-842.

Bobe, R., 2007.Patterns of abundance and diversity in late Cenozoic bovids from the Turkana and Hadar Basins, Kenya and Ethiopia.In: Bobe, R., Alemseged, Z., Behrensmeyer, K. (Eds.), Hominin environments in the East African Pliocene: an assessment of the faunal evidence. Springer, Dordrecht, pp. 129-157.

Boisserie, J.-R., 2005. The phylogeny and taxonomy of Hippopotamidae (Mammalia: Artiodactyla): a review based on morphology and cladistic analysis. Zool. J. Linn. Soc. $143,1-26$.

Boisserie, J.-R.,Zazzo, A., Merceron, G., Blondel, C., Vignaud, P., Likius, A., Mackaye, H.T., Brunet, M., 2005.Diets of modern and late Miocene hippopotamids: evidence from carbon isotope composition and micro-wear of tooth enamel. Palaeogeogr. Palaeoclimat. Palaeoecol. 221, 153-174.

Brown, B., Brown, F.H., Walker, A., 2001. New hominids from the Lake Turkana basin, Kenya. J. Hum. Evol. 41, 29-44.

Brown, F.H., McDougall, I., Gathogo, P.N., 2013. Age Ranges of Australopithecus Species, Kenya, Ethiopia, and Tanzania. In: Reed, K.E., Fleagle, J.G., Leakey, R.E. (Eds.), The Paleobiology of Australopithecus. Springer, Dordrecht, pp. 7-20.

Brunet, M., Beauvilain, A., Coppens, Y., Heintz, E., Moutaye, A.E., Pilbeam, D., 1995.The first australopithecine 2,500 kilometres west of the Rift Valley (Chad). Nature 378, 273-275. 
Cerling, T.E., Harris, J.M., Passey, B.H., 2003. Diets of East African Bovidae based on stable isotope analysis. J. Mammal. 84, 456-470.

Cerling, T.E.,Wynn, J.G., Andanje, S.A., Bird, M.I., Korir, D.K., Levin, N.E., Mace, W., Macharia, A.N., Quade, J., Remien, C.H., 2011. Woody cover and hominin environments in the past 6 million years. Nature 476, 51-56.

Cerling, T.E., Manthi, F.K., Mbua, E., Leakey L.N., Leakey, M.G., Leakey, R.E., Brown, F.H., Grine, F.E., Hart, J.A., Kaleme, P., Roche, H., Uno, K.T., Wood, B.A., 2013. Stable isotope-based diet reconstructions of Turkana Basin hominins. Proc. Natl. Acad. Sci. USA 110, 10501-10506.

DiMaggio, E.N., Campisano, C.J., Rowan, J., Dupont-Nivet, G., Deino, A.L., Bibi, F., Lewis, M.E., Souron, A., Garello, D., Werdelin, L., Reed, K.E., Arrowsmith, J.R., 2015. Late Pliocene fossiliferous sedimentaryrecord and the environmental context ofearly Homo from Afar, Ethiopia. Science 347, 1355-1359.

Ditchfield, P., Harrison, T., 2011.Sedimentology, lithostratigraphy and depositional history of the Laetoli area. In: Harrison, T. (Ed.), Paleontology and Geology of Laetoli: Human Evolution in Context. Vol. 1: Geology, Geochronology, Paleoecology and Paleoenvironment. Springer, Dordrecht, pp. 47-76.

Drapeau, M.S.M., Ward, C.V., Kimbel, W.H., Johanson, D.C., Rak, Y., 2005. Associated cranial and forelimb remains attributed to Australopithecus afarensis from Hadar, Ethiopia. J. Hum. Evol. 48, 593-642.

Eisenmann, V., Geraads, D., 2007.The hipparion from the late Pliocene of Ahl al Oughlam, Morocco, and a revision of the relationships of Pliocene and Pleistocene African hipparions. Palaeont. Afr. 42, 51-98.

Gentry, A.W., 1985.The Bovidae of the Omo Group deposits, Ethiopia (French and American collections). In: Coppens, Y., Howell, F.C. (Eds.), Les faunes plio-pléistocènes de la basse vallée de l'Omo (Éthiopie). Tome 1 Périssodactyles, Artiodactyles (Bovidae). Éditions du CNRS, Paris, pp. 119-214.

Gentry, A.W., 1987.Pliocene Bovidae from Laetoli. In: Leakey, M.D., Harris, J.M. (Eds.), Laetoli, a Pliocene Site in Northern Tanzania. Clarendon Press, Oxford, pp. 378-408. 
Gentry, A.W., 2011. Bovidae. In: Harrison, T., (Ed.), Paleontology and Geology of Laetoli:

Human Evolution in Context. Vol. 2: Fossil hominids and the associated fauna. Springer, Dordrecht, pp. 363-465.

Gentry, A.W., Gentry, A, 1978. Fossil Bovidae (Mammalia) of Olduvai Gorge, Tanzania. Part I. Bull. Brit. Mus. (Nat. Hist.) Geol. 29, 289-446.

Gèze, R., 1985.Répartition paléoécologique et relations phylogénétiques des Hippopotamidae (Mammalia, Artiodactyla) du néogène d'Afrique Orientale. In: Fondation SingerPolignac (Ed.), L'environnement des hominidés au Plio-Pléistocène. Masson, Paris, pp. $81-100$.

Geraads, D., 2005. Pliocene Rhinocerotidae (Mammalia) from Hadar and Dikika (Lower Awash, Ethiopia), and a revision of the origin of modern African rhinos. J. Vert.Paleontol. 25, $451-461$.

Geraads, D., Eisenmann, V., Petter, G., 2004. The Large Mammal Fauna of the Oldowayan sites of Melka-Kunturé, Ethiopia. In: Chavaillon, J., Piperno, M. (Eds.), Studies on the Early PalaeolithicSite of Melka Kunture, Ethiopia. IstitutoItaliano diPreistoria e Protostoria, Roma, pp. 169-192.

Geraads, D., Melillo, S., Haile-Selassie, Y., 2009. Middle Pliocene Bovidae from hominidbearing sites in the Woranso-Mille area, Afar region, Ethiopia. Palaeont. Afr. 44, 59-70.

Geraads, D., Bobe, R., Reed, K., 2012. Pliocene Bovidae (Mammalia) from the Hadar Formation of Hadar and Ledi-Geraru, Lower Awash, Ethiopia. J. Vert.Paleontol. 32, 180-197.

Guth, A.,Wood, J.,2013. Geological Map of the Southern Kenya Rift. Digital Map and Chart Series DMCH016. Geological Society of America.

Haile-Selassie, Y., Latimer, B.M., Alene, M., Deino, A.L., Gibert, L., Melillo, S.M., Saylor, B.Z., Scott, G.R., Lovejoy, C.O., 2010.An early Australopithecus afarensispostcranium from Woranso-Mille, Ethiopia. Proc. Natl. Acad. Sci. USA 107, 12121-12126.

Harris, J.M., 1991. Family Bovidae. In: Harris, J.M., (Ed.), Koobi Fora Research Project, Vol. 3 : The Fossil Ungulates: Geology, Fossil Artiodactyls and Palaeoenvironments. Clarendon Press, Oxford, pp. 139-320.

Harris, J.M., Cerling, T.E., 2002. Dietary adaptations of extant and Neogene African suids. J. Zool. Lond. 256, 45-54. 
Harris, J.M., Leakey, M.G., Cerling, T.E., Winkler, A.J., 2003. Early Pliocene tetrapod remains from Kanapoi, Lake Turkana Basin, Kenya. In: Harris, J.M., Leakey, M.G. (Eds.), Geology and Vertebrate Paleontology of the Early Pliocene site of Kanapoi, Northern Kenya (Contributions in Science 498). Natural History Museum of Los Angeles County, Los Angeles, pp. 39-113.

Harris, J.M., Cerling, T.E., Leakey, M.G., Passey, B.H., 2008. Stable isotope ecology of fossil hippopotamids from the Lake Turkana Basin of East Africa. J. Zool. 275, 323-331.

Harrison, T., 2011. Laetoli revisited: renewed paleontological and geological investigations at localities on the Eyasi Plateau in Northern Tanzania. In: Harrison, T. (Ed.), Paleontology and Geology of Laetoli: Human Evolution in Context. Vol. 1: Geology, Geochronology, Paleoecology and Paleoenvironment. Springer, Dordrecht, pp. 1-15.

Hirata, T., Nesbitt, R.W., 1995. U-Pb isotope geochronology of zircons: Evaluation of the laser probe inductively coupled plasma-mass spectrometry technique. Geochim. Cosmochim. Acta 59, 2491-2500.

Iizuka, T., Hirata, T., 2004.Simultaneous determinations of U-Pb age and REE abundances for zircons using ArFexcimer laser-ICPMS. Geochem. J. 38, 229-241.

Iwano, H., Orihashi, Y., Danhara, T., Hirata, T., Ogasawara, M., 2012. Evaluation of fissiontrack and $\mathrm{U}-\mathrm{Pb}$ double dating method for identical zircon grains- Using homogeneous zircon grains in Kawamoto Granodiorite in Shimane prefecture, Japan. J. Geol. Soc. Japan 118, 365-375.

Iwano, H., Orihashi, Y., Hirata, T., Ogasawara, M., Danhara, T., Horie, K., Hasebe, N., Sueoka, S., Tamura, A., Hayasaka, Y., Katsube, A., Ito, H., Tani, K., Kimura, K., Chang, Q., Kouchi, Y., Haruta, Y., Yamamoto, K., 2013. An inter-laboratory evaluation of OD-3 zircon for use as a secondary U-Pb dating standard. Island Arc 22, 382-394.

Jablonski, N.G., Leakey, M.G. (Eds.), 2008. Koobi Fora Research Project: Volume 6. The Fossil Monkeys. California Academy of Science, San Francisco.

Kimbel, W.H., 1988. Identification of a partial cranium of Australopithecus afarensis from the Koobi Fora Formation, Kenya. J. Hum. Evol. 17, 647-656.

Kimbel, W.H., Delezene, L.K.,2009. Lucy redux: A review of research on Australopithecus afarensis. Yearb. Phys. Anthropol. 140, 2-48. 
Kingston, J.D., 2011. Stable isotopic analyses of Laetoli fossil herbivores. In: Harrison, T. (Ed.), Paleontology and Geology of Laetoli: Human Evolution in Context. Vol. 1: Geology, Geochronology, Paleoecology and Paleoenvironment. Springer, Dordrecht, pp. 293-328. Kingston, J.D., Harrison, T., 2007. Isotopic dietary reconstructions of Pliocene herbivores at Laetoli: implications for early hominin paleoecology. Palaeogeogr. Palaeoclimatol. Palaeoecol. 243, 272-306.

Kuiper, K.F., Deino, A., Hilgen, F.J., Krijgsman, W., Renne, P.R., Wijbrans, J.R., 2008. Synchronizing rock clocks of Earth history. Science 320, 500-504.

Leakey, M.G., Feibel, C.S., McDougal, I. Ward, C., Walker, A., 1998. New specimens and confirmation of an early age for Australopithecus anamensis. Nature 393, 62-66.

Leakey, M.G., Spoor, F., Brown, F.H., Gathogo, P.N., Kiarie, C., Leakey, L.N., McDougall, I., 2001. New hominin genus from eastern Africa shows diverse middle Pliocene lineages. Nature 410, 433-440.

Lockley, M., 1991. Tracking Dinosaurs. Cambridge Univ. Press,.

Ludwig, K.R., 2008. User's Manual for Isoplot 3.6. A Geochronological Toolkit for Microsoft Excel. Berkeley Geochronology Center, Berkeley.

McHenry, H.M., Corruccini, R.S., Howell, F.C., 1976. Analysis of an early hominid ulna from the Omo Basin, Ethiopia. Am. J. Phys.Anthropol. 44, 295-304.

Miall, A.D., 1996. The Geology of Fluvial Deposits, Sedimentary Facies, Basin Analysis and Petroleum Geology. Springer, Berlin.

Moggi-Cecchi, J., Grine, F.E., Tobias, P.V., 2006. Early hominid dental remains from Members 4 and 5 of the Sterkfontein Formation (1966-1996 excavations): catalogue, individual associations, morphological descriptions and initial metrical analysis. J. Hum. Evol. 50, 239-328.

Nash, W.P., 1992. Analysis of oxygen with the electron microprobe: Applications to hydrated glass and minerals. Amer. Mineral. 77, 453-457.

Nemec, W., 1990.Aspects of sediment movement on steep delta slope. In: Cokella, A., Prior, D.B. (Eds.), Coarse-grained Deltas. Blackwell, Oxford, pp. 29-73.

Ogg, J.G., 2012.Geomagnetic polarity time scale. In: Gradstein, F.M., Ogg, J.G, Schmitz, M.D., Ogg, G.M. (Eds.), The Geologic Time Scale, Vol. 1. Elsevier, Boston, pp. 85-113. 
Reed, K.E., 1998. Using large mammal communities to examine ecological and taxonomic structure and predict vegetation in extant and extinct assemblages. Paleobiology 24, 384408.

Reed, K.E., 2008. Paleoecological patterns at the Hadar hominin site, Afar Regional State, Ethiopia. J. Hum. Evol. 54, 743-768.

Saggerson, E.P., 1991. Geological Map of the Nairobi Area.Mines and Geology Department, Nairobi.

Sakata, S., Hattori, K., Iwano, H., Yokoyama, T.D., Danhara, T., Hirata, T., 2014. Determination of $\mathrm{U}-\mathrm{Pb}$ ages for young zircons using a laser ablation-ICP-mass spectrometry coupled with an ion detection attenuator device. Geostand. Geoanal. Res.38, 409-420.

Smith, G.A., Fritz, W.J., 1989. Volcanic influences on terrestrial sedimentation. Geology 17, $375-376$.

Smith, M.E., Singer, B.S., Carroll, A.R., Fournelle, J.H., 2008. Precise dating of biotite in distal volcanic ash: Isolating subtle alteration using ${ }^{40} \mathrm{Ar} /{ }^{39} \mathrm{Ar}$ laser incremental heating and electron microprobe techniques. Amer. Mineral. 93, 784-795.

Steiger, R.H., Jäger, E., 1977. Subcommission on geochronology: convention on the use of decay constants in geo- and cosmochronology. Earth Planet. Sci. Lett. 36, 359-362.

$\mathrm{Su}$, D.F., 2011. Large mammal evidence for the paleoenvironment of the Upper Laetoli and Upper Ndolanya beds of Laetoli, Tanzania.In: Harrison, T. (Ed.), Paleontology and Geology of Laetoli: Human Evolution in Context. Vol. 1: Geology, Geochronology, Paleoecology and Paleoenvironment. Springer, Dordrecht, pp. 381-392.

Su, D.F., Harrison, T., 2007. The paleoecology of the Upper Laetolil Beds at Laetoli.A reconsideration of the large mammal evidence.In: Bobe, R., Alemseged, Z., Behrensmeyer, K. (Eds), Hominin environments in the East African Pliocene: an assessment of the faunal evidence. Springer, Dordrecht, pp. 279-310.

Uno, K.T., Cerling, T.E., Harris, J.M., Kunimatsu, Y., Leakey, M.G., Nakatsukasa, M., Nakaya, H., 2011. Late Miocene to Pliocene carbon isotope record of differential diet change among east African herbivores. Proc. Natl. Acad. Sci. USA 108, 6509-6514.

Ward, C.V., Leakey, M.G., Brown, B., Brown, F., Harris, J., Walker, A., 1999. South Turkwel: a new Pliocene hominid site in Kenya. J. Hum. Evol.36, 69-95. 
Ward, C.V., Plavcan, J.M.,Manthi, F.K.,2010. Anterior dental evolution in the Australopithecus anamensis-afarensislineage. Phil. Trans. R. Soc. B 365, 3333-3344.

Weston, E., Boisserie, J.-R., 2010. Hippopotamidae. In: Werdelin, L., Sanders, W.J. (Eds.), Cenozoic Mammals of Africa. University of California Press, Berkeley, pp. 853-871.

Weston, E.M., 2003.Fossil Hippopotamidae from Lothagam. In: Leakey, M.G., Harris, J.M. (Eds.), Lothagam: The Dawn of Humanity in Eastern Africa. Columbia University Press, New York, pp 441-483.

White, T.D., Suwa, G., Hart, W.K., Walter, R.C., WoldeGabriel, G., Heinzelin, J. de, Clark, J.D., Asfaw, B., Vrba, E., 1993. New discoveries of Australopithecus at Maka, Ethiopia. Nature 366, 261-265.

White, T.D., Suwa, G., Asfaw, B.,1994. Australopithecus ramidus, a new species of early hominid from Aramis, Ethiopia. Nature 371, 306-312.

Wiedenbeck, M., Alle, P., Corfu, F., Griffin, W.L., Meier, M., Oberli, F., Von Quadt, A., Roddick, J.C., Spiegel, W., 1995. Three natural zircon standards for U-Th-Pb, Lu-Hf, trace element and REE analyses. Geostand. Newslett. 19, 1-23.

Wood, B., Leakey, M., 2011. The Omo-Turkana Basin fossil hominins and their contribution to our understanding of human evolution in Africa. Evol. Anthropol. 20, 264-292.

Yokoyama, T.D., Suzuki, T., Kon, Y., Hirata, T., 2011. Determinations of rare earth element abundance and $\mathrm{U}-\mathrm{Pb}$ age of zircons using multispot laser ablation-inductively coupled plasma mass spectrometry. Analytical Chem. 83, 8892-8899. 


\section{Figure legends}

Figure 1. Location maps of Kantis Fossil Site (KFS). a) The map showing Australopithecus sites mentioned in the text. b) Location of KFS in Kenya.

Figure 2. Columnar cross sections of the fossil site. Location of each section in the excavation site is indicated in the left upper inset. Strata at the KFS are divided into four beds (Level 1-3 and the Kantis Tuff) and are truncated by a terrace deposit. $\mathrm{m}=$ mud, $\mathrm{s}=$ sand, $\mathrm{g}=$ gravel.

Figure 3. Photographic explanation of sedimentary strata at the KFS. a) KFS main Trench. b) View of the outcrop. Note the poorly sorted gravel bed of Level 1 and the lenticular Kantis Tuff that tapers out at the left margin of the photograph. c) Close-up view of Level 1. Note that coarse gravels are scattered in fine sediments, showing matrix-supported nature. d) The Kantis Tuff bed. The dotted lines indicate traces of footprint. The local concave up stratal deformation (arrow) is interpreted as an underprint marked by a large animal.

Figure 4. Diagrams showing U-Pb age data determined for two samples KY13011903 (a) and KY13012102 (b) obtained from the fossil bed. The left panels are concordia diagrams using youngest grain data. The right panels show ${ }^{238} \mathrm{U}_{-}{ }^{206} \mathrm{~Pb}$ age distributions, excluding any discordant data. All age data were calculated and plotted using Isoplot 3.6 (Ludwig, 2008) and error bars are shown at the 2 s.d. level.

Figure 5. Results of paleomagnetic analysis. a) Representative results of alternative field (AF) and thermal demagnetization (Th) shown as Zijderveld vector diagrams. Open and closed circles show projections onto the vertical and horizontal planes, respectively. Numbers following the sampling location (KDl 5: see Fig. 2) denote specimen numbers. $\mathrm{J}_{0}=$ magnetic intensity before demagnetization. b) Directions of characteristic remnant magnetizations from the five locations. Open and filled circles show equal-area projections in the upper and lower hemisphere, respectively.

Figure 6. Hominin fossil materials. a) KNM-RK 53001, a left dp3 (upper row), and KNM-RK 53000, a left dp3 (lower row). From left to right: occlusal (stereo), buccal, and lingual views. Scale $=5 \mathrm{~mm}$ b) Lower dp3s of Australopithecus spp. From left to right; Au. afarensis L.H. 2 (cast); Au. afarensis A.L. 33-43b (cast); Au. Anamensis KNM-KP 34725 (original); Au. africanus 
Taung Child (cast). Except KNM-KP 34725, images were cropped from photographs of the mandibular right dental row and inverted for comparative purpose. Scale $=5 \mathrm{~mm} \mathrm{c}$ ) KNM-RK 57800, a left upper canine. From left to right: lingual, distal, labial, and mesial views. Scale $=1$ $\mathrm{cm}$ d) Upper canine comparison. Left panel = lingual view, right panel = buccal view. Left to right: Au. afarensis L.H. 3 (left side, cast), KNM-RK 57800 (left side), Au. anamensis KNM-KP 35893 (right side). e) KNM-RK 53525, a proximal half portion of an adult left ulna. Eroded parts are shown with shading. Abbreviations: $\mathrm{sp}$ and arrow heads $=$ supinator crest, $\mathrm{ic}=$ interosseous crest, $\mathrm{br}=$ insertion of the brachialis muscle, $\mathrm{fd}=$ origin of the flexor digitorum superficialis and pronator teres muscles. Scale $=5 \mathrm{~cm}$

Figure 7. Comparative photographs of fossil hominin ulnae. Right specimens are reversed for comparison. Lateral (top) and anterior view (bottom). From left to right: KNM-RK 53525, Au. afarensis A. L. 438-1, Au. afarensis A.L. 288-1, Au. sediba UW-88-62, c.f. Paranthropus boisei $\mathrm{OH} 36$, Hominini indet. L40-19. Scales $=1 \mathrm{~cm}$

Figure 8. Correspondence analysis of the number of large mammal species $(>5 \mathrm{~kg})$ in each dietary and locomotor category, in modern and fossil African assemblages, as in Reed (1998, 2008). Variables are: $\mathrm{A}=$ arboreal, $\mathrm{AQ}=$ aquatic, $\mathrm{T}=$ terrestrial, $\mathrm{TA}=$ terrestrial/arboreal, $\mathrm{B}=$ browser, $\mathrm{C}=$ meat, $\mathrm{CB}=$ meat/bone, $\mathrm{CI}=$ meat/invertebrates, $\mathrm{F}=$ fruits, $\mathrm{FG}=$ fresh grass, $\mathrm{FI}=$ fruit/insects, $\mathrm{FL}=$ fruits/leaves, $\mathrm{G}=$ grazers, $\mathrm{I}=$ insects, $\mathrm{MF}=$ mixed feeders, $\mathrm{OM}=$ omnivorous, $\mathrm{R}=$ roots/bulbs. Only modern localities are active and plotted with a symbol from 1 (forest) to 7 (desert), as in Reed (1998:App.1). All fossil localities are illustrative and plot within the lower right rectangle, enlarged at the upper left. Data for modern localities from Reed (1998). Category assignments may differ from previously published ones.

Figure 9. Correspondence analysis of the number of specimens in each bovid tribe, in East African fossil localities. Data from Su (2011:Table 19.6), Bobe et al. (2007), the Turkana database, Omo catalog, and Hadar catalog (by C. Campisano, identifications updated by DG). Open symbols are illustrative. Open circles are the individual localities of the Upper Laetolil Beds (only the total is used as an active variable). 
Figure 10. Box and whisker plots of stable carbon isotope ratios $\left(\delta^{13} \mathrm{C}\right)$ obtained from fossilized mammal tooth enamel in the KFS and other Au. afarensis sites (for the data source, see Table 5). Taxon pooled data (top left) and data by family are shown. 

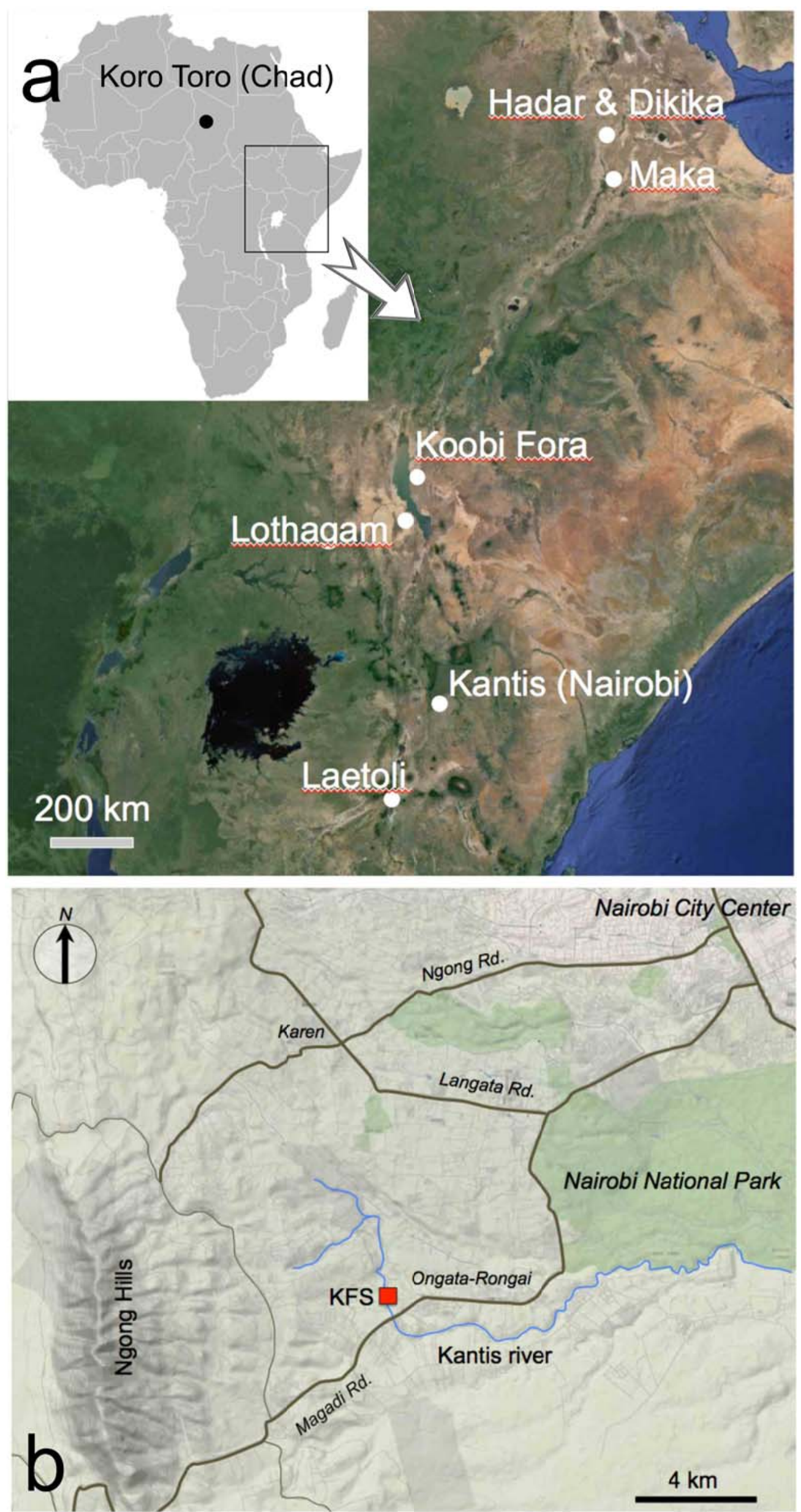
Figure 2

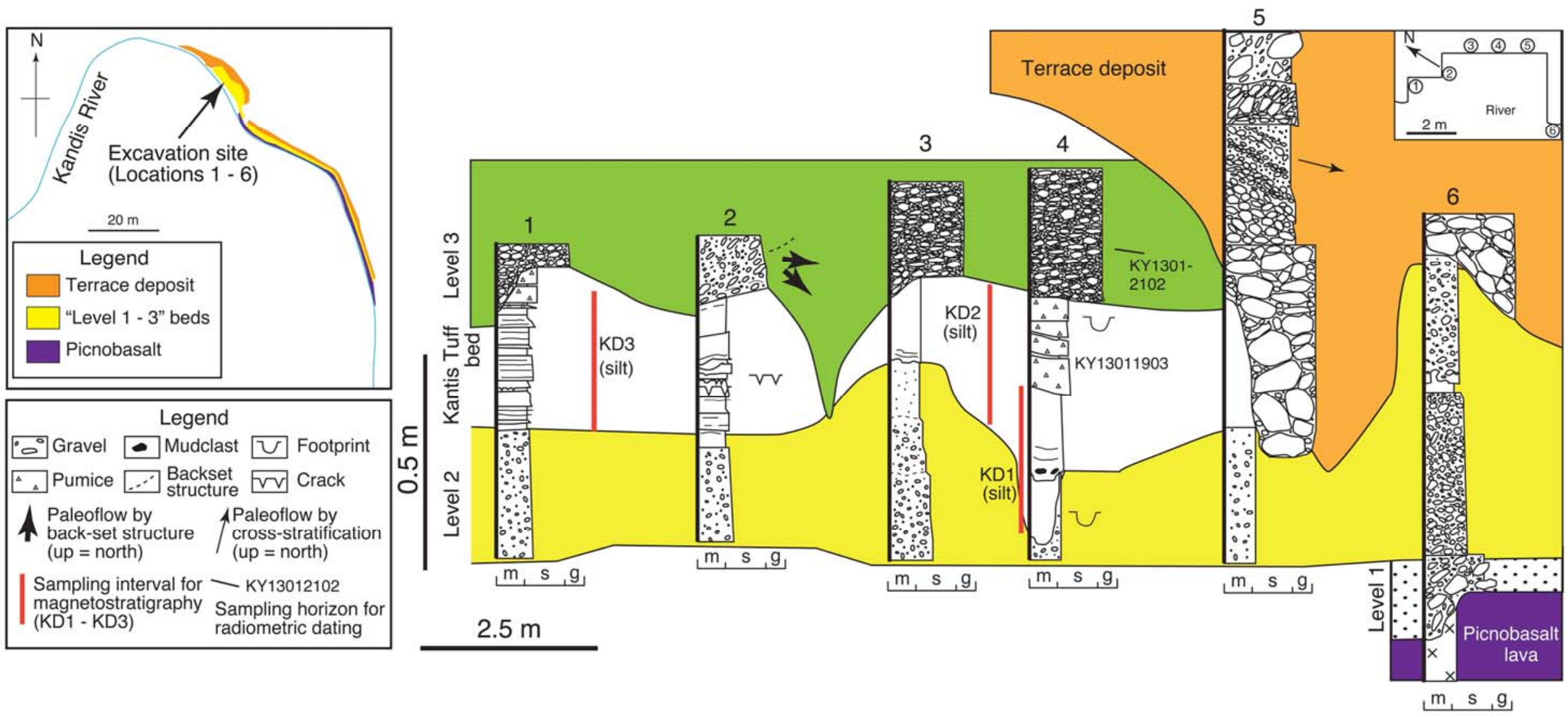




\section{Figure 3}
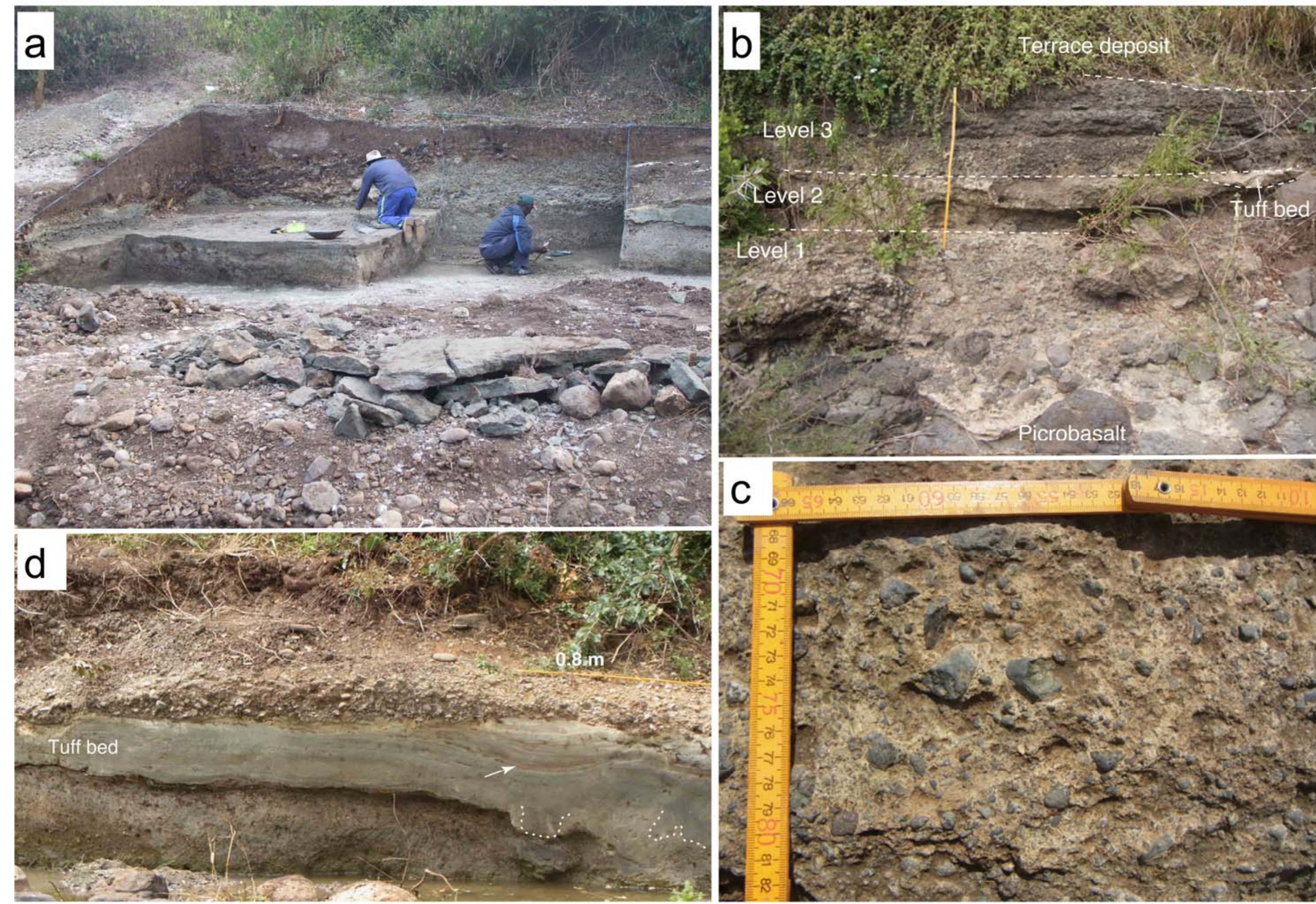
Figure 4

\section{Kantis tuff (KY13011903B)}

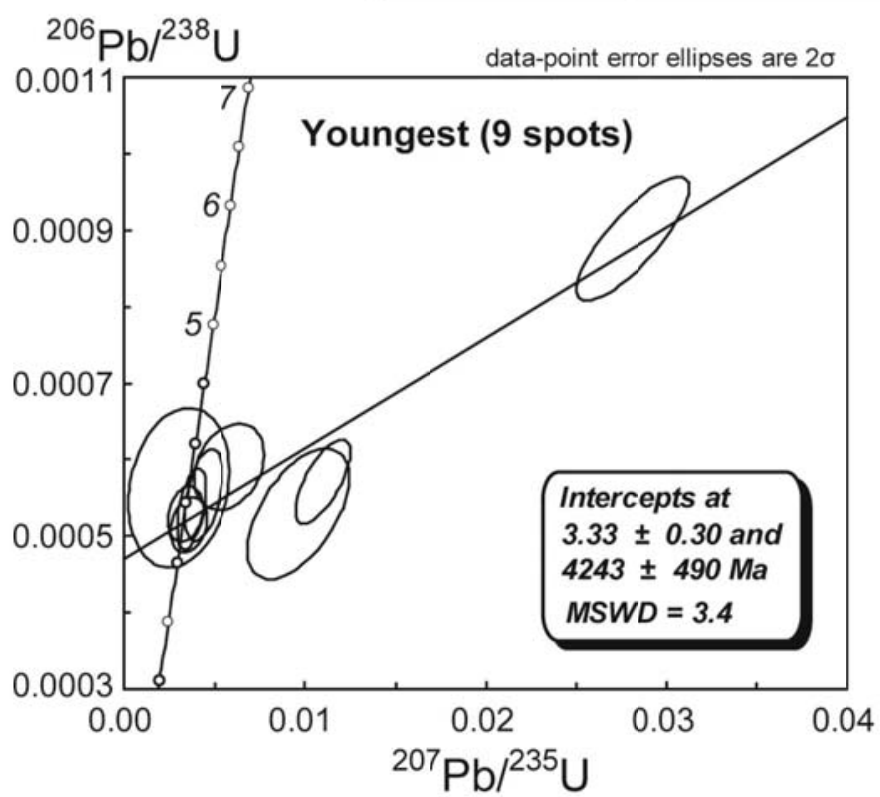

Age (Ma)

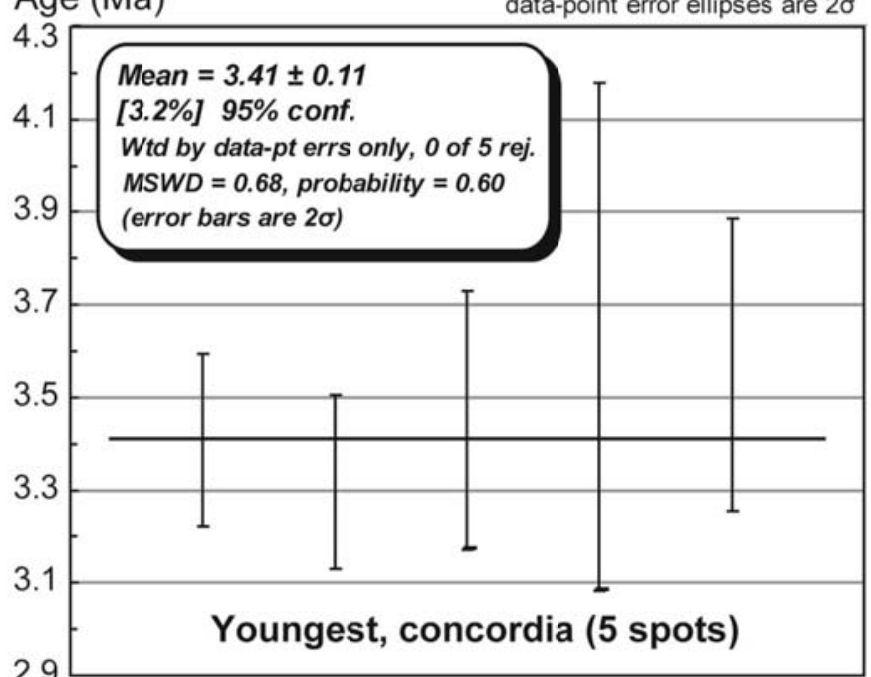

\section{Volcanic mud flow (KY13012102)}

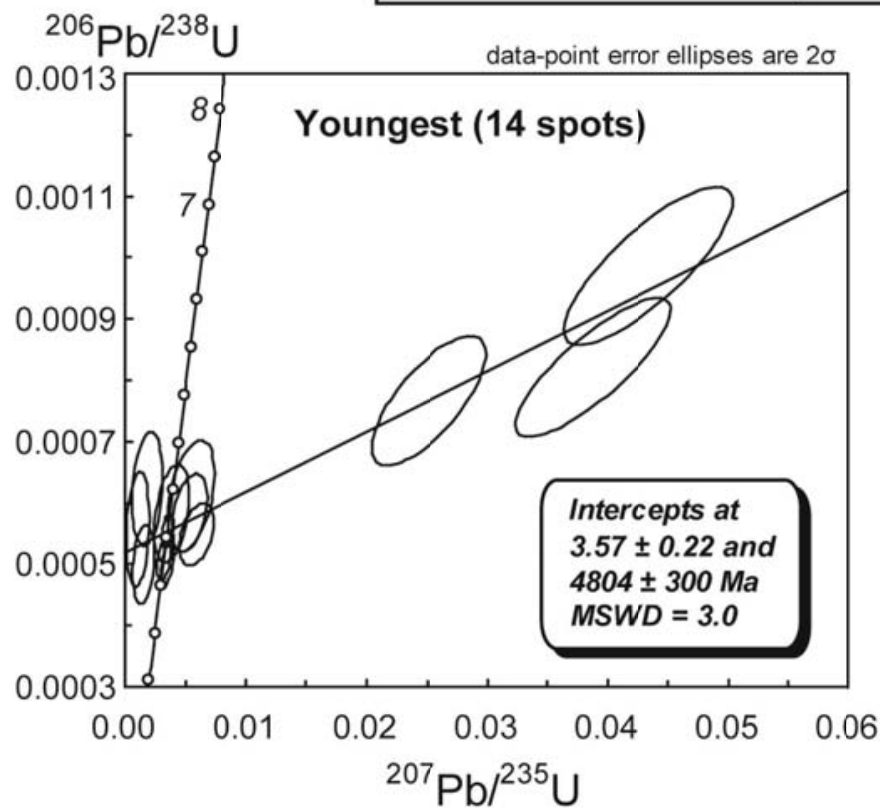

Age (Ma)

data-point error ellipses are 20

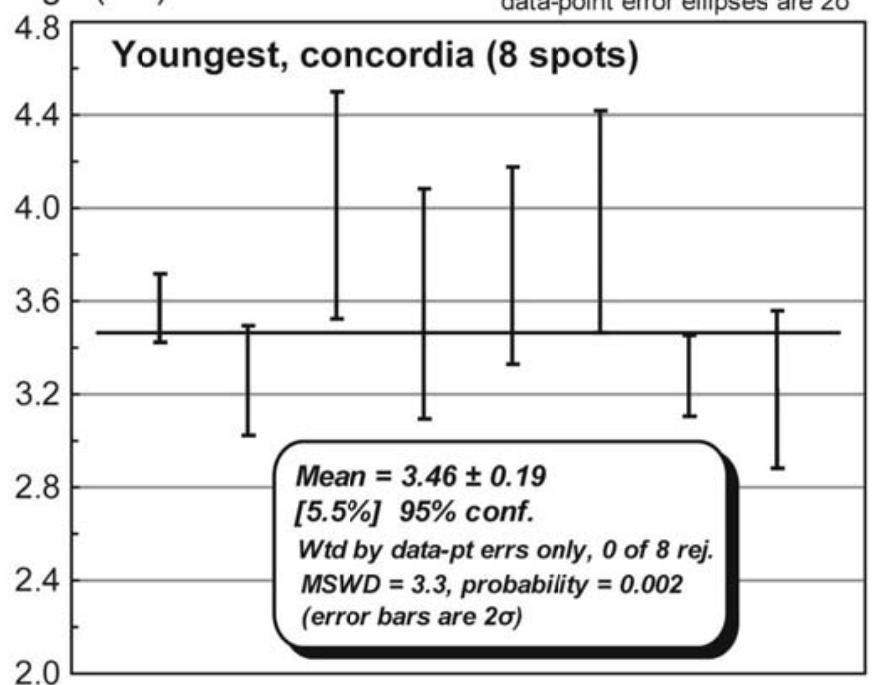

${ }^{207} \mathrm{~Pb} /{ }^{235} \mathrm{U}$ 


\section{Figure 5}
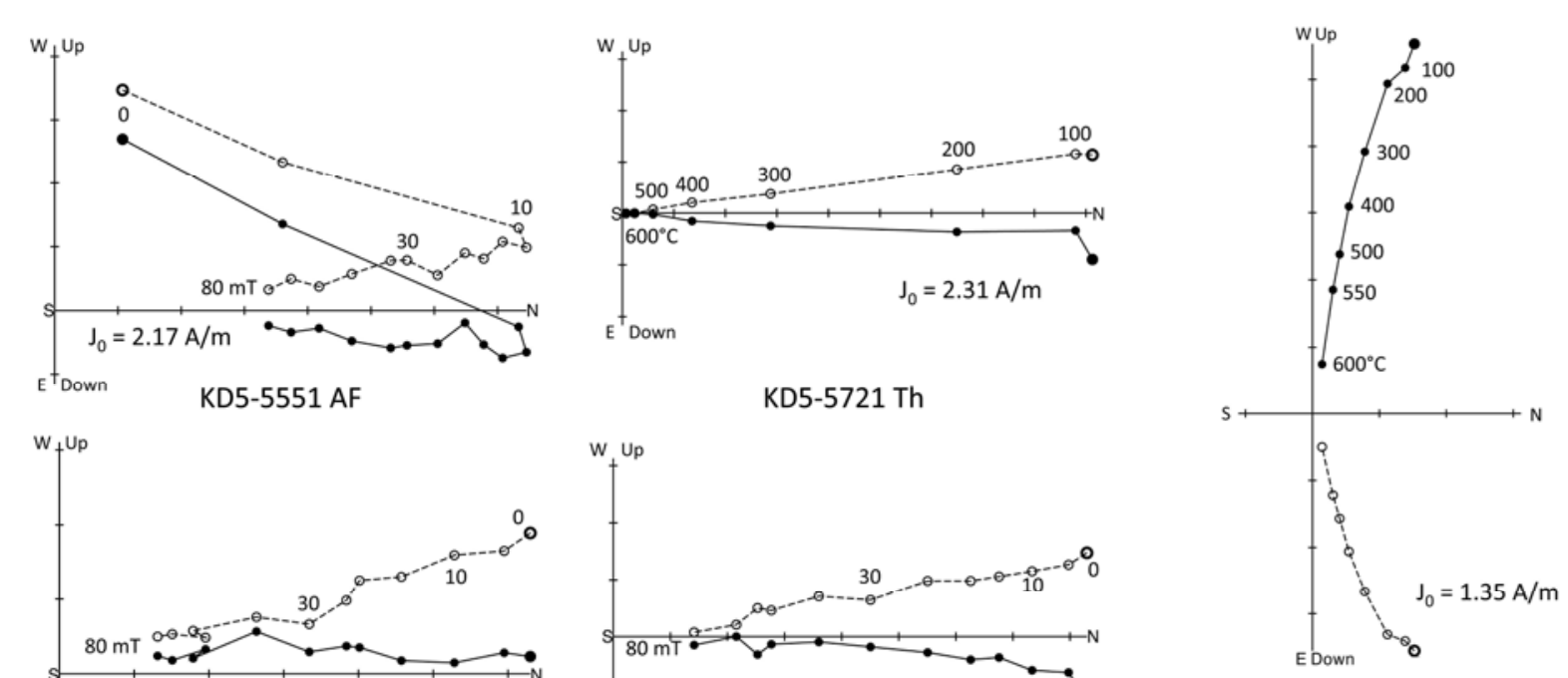

KD5-5311 Th

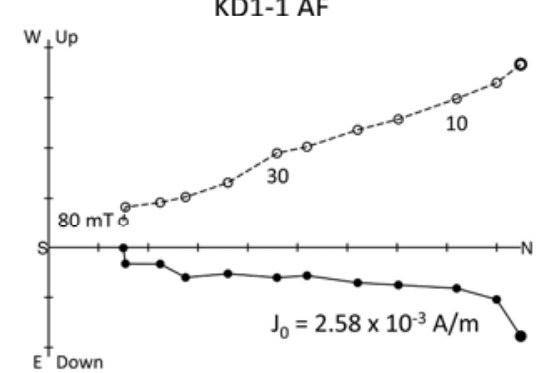

a
KD2-1 AF
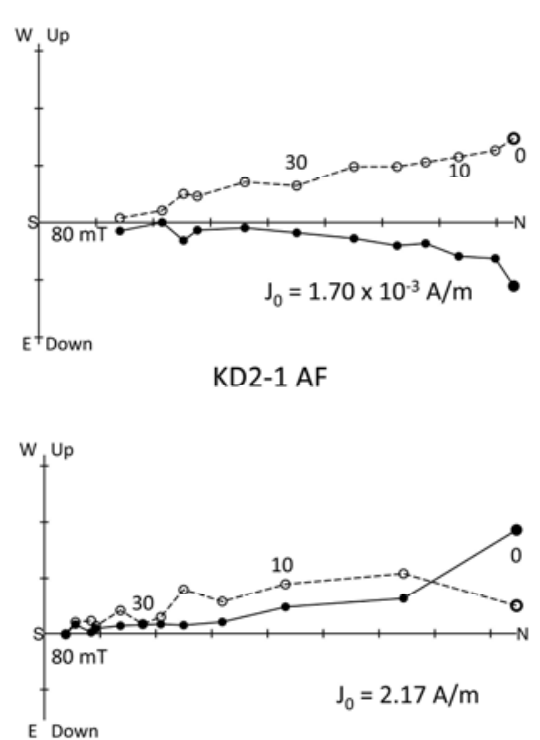

KD4-4111 AF

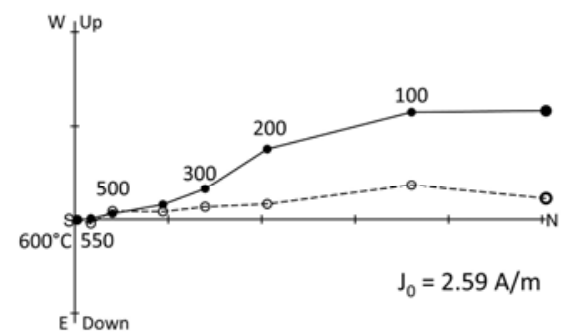

KD4-4521 Th
KD5

Trachytic pyroclastic flow deposit

KD4

Ankaramite lava

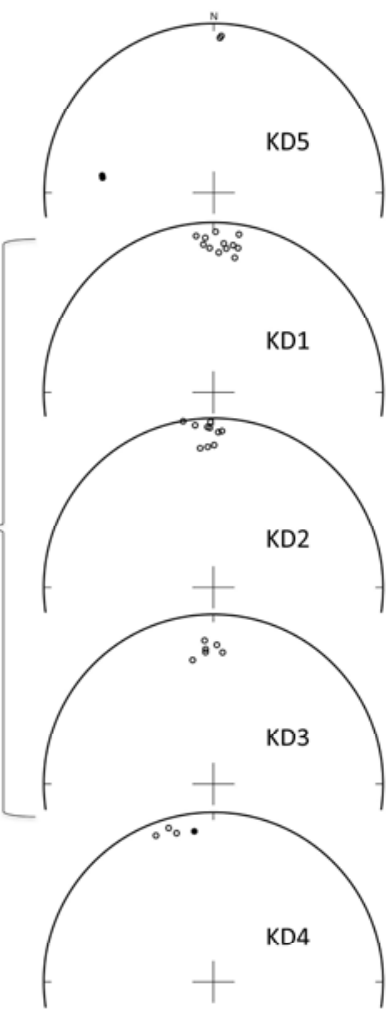

b 
Figure 6
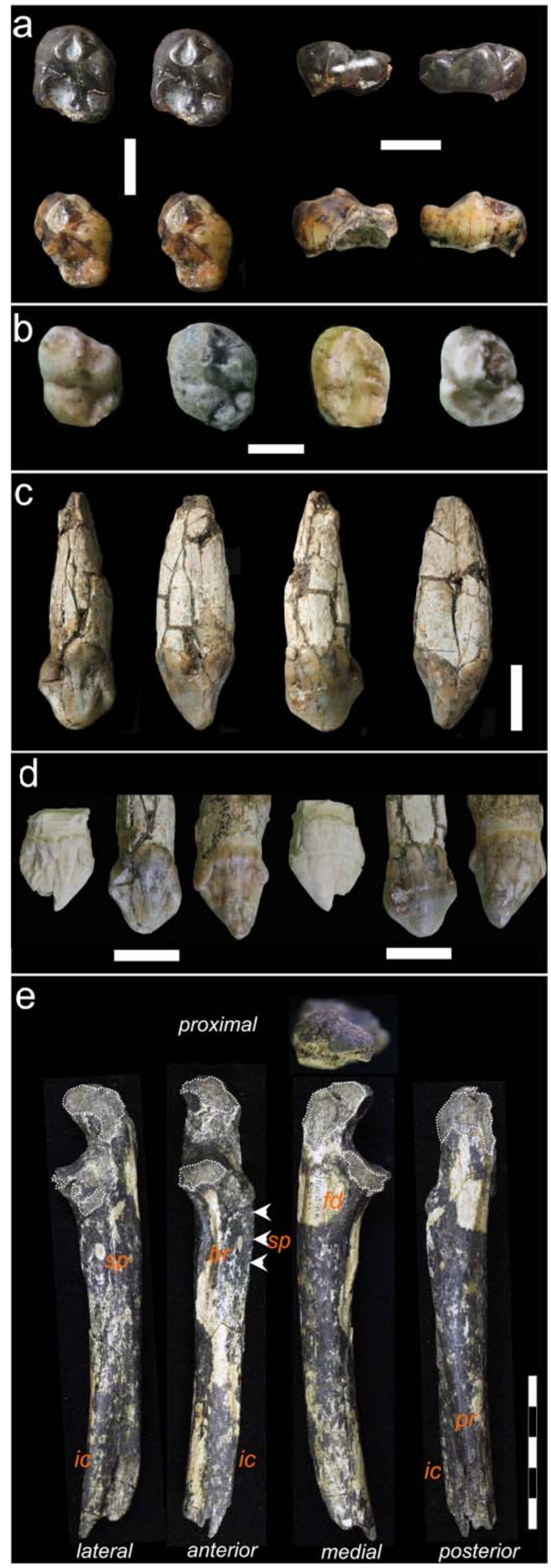

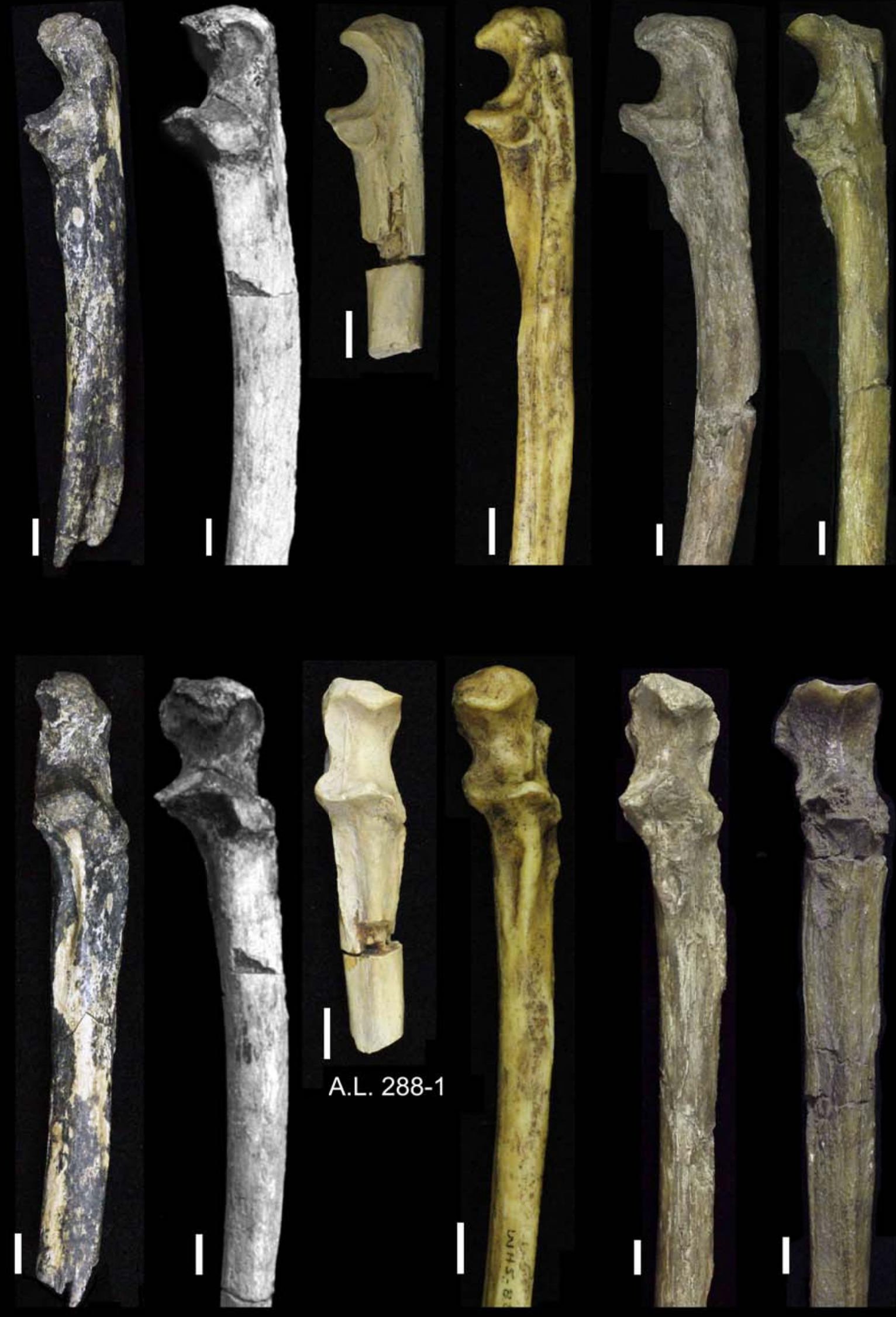

KNM-RK 53525

A.L. $438-1$

UW-88-62

$\mathrm{OH} 36$

L40-19 
Figure 8

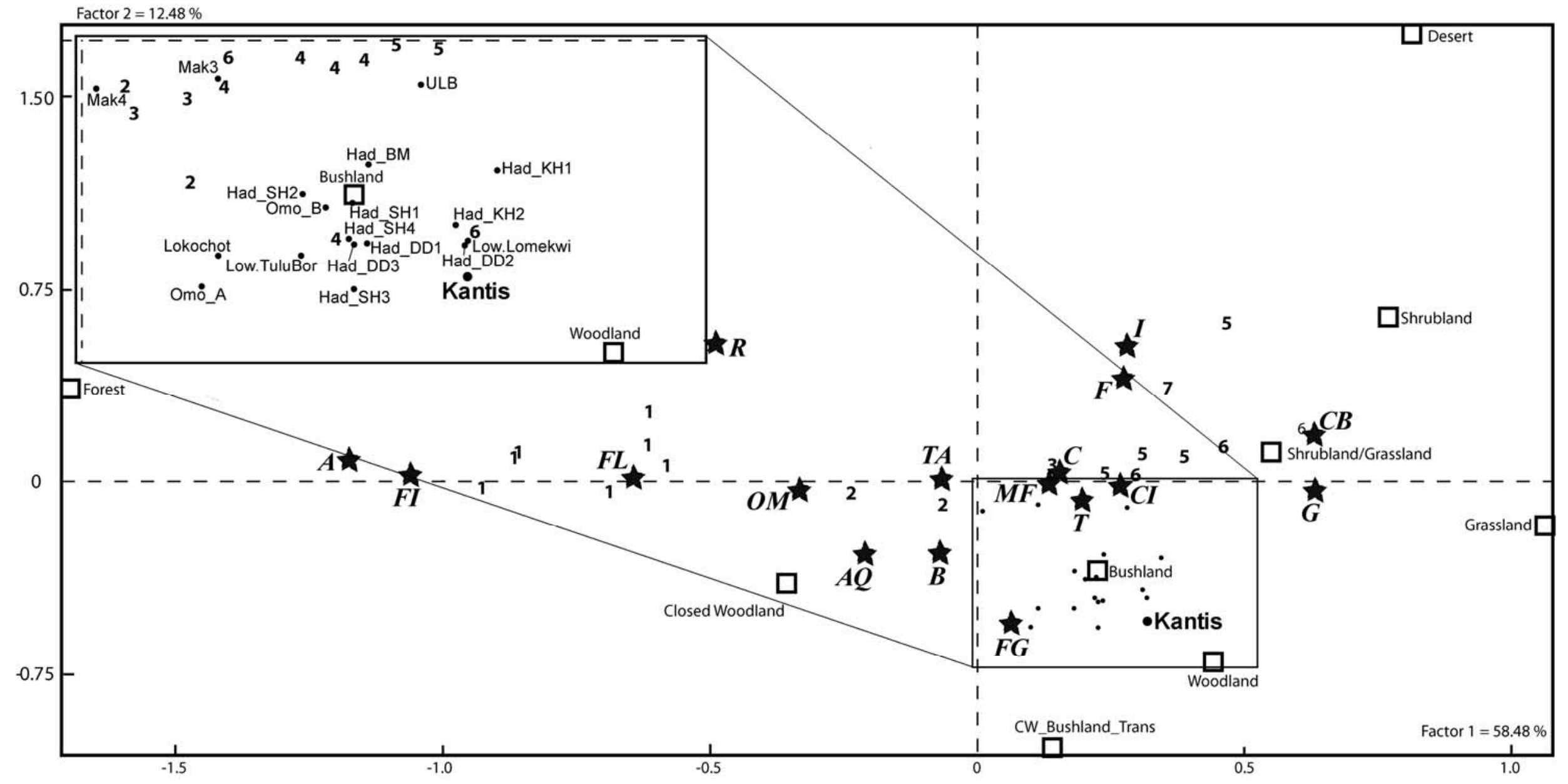


Figure 9

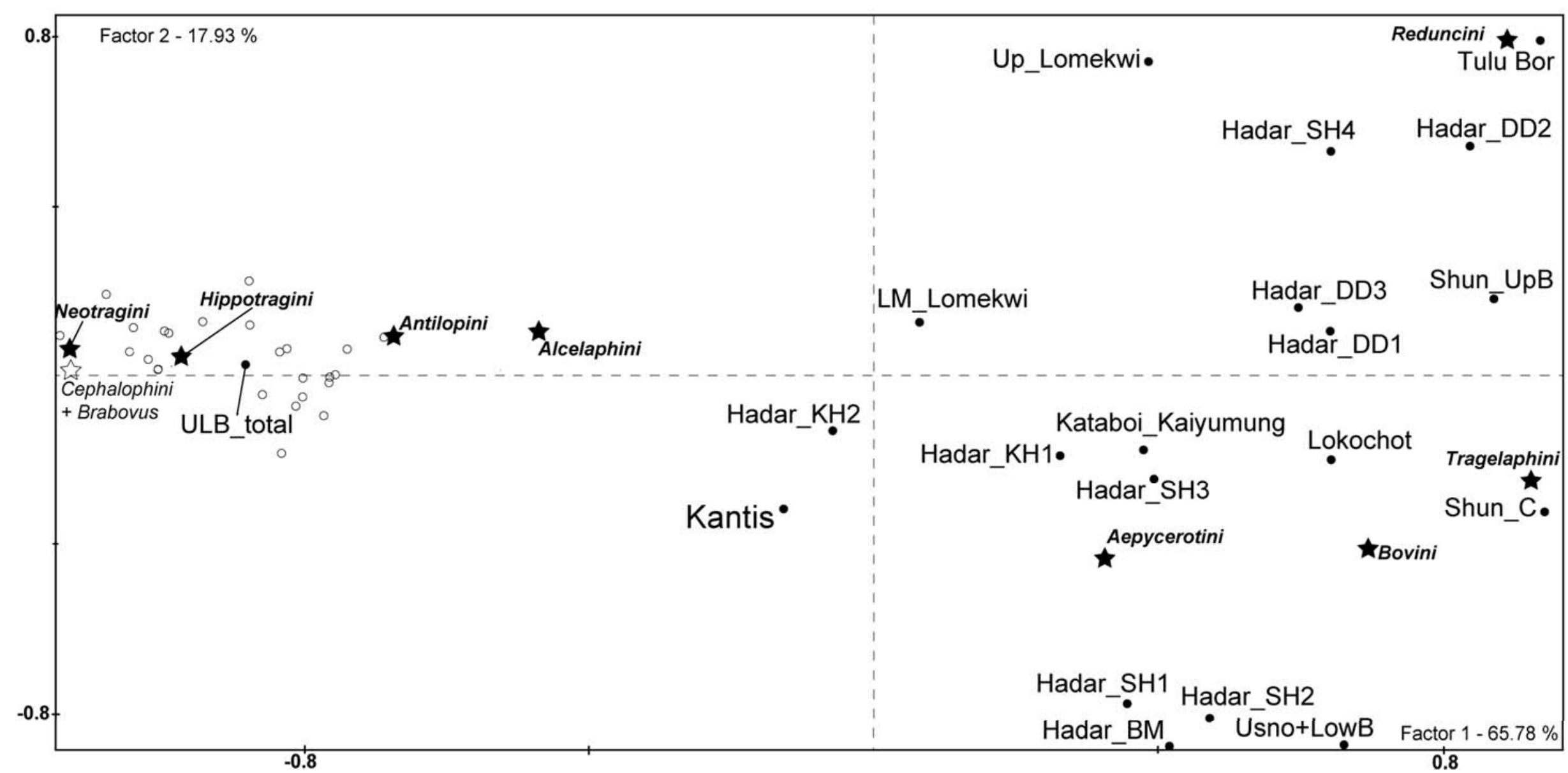




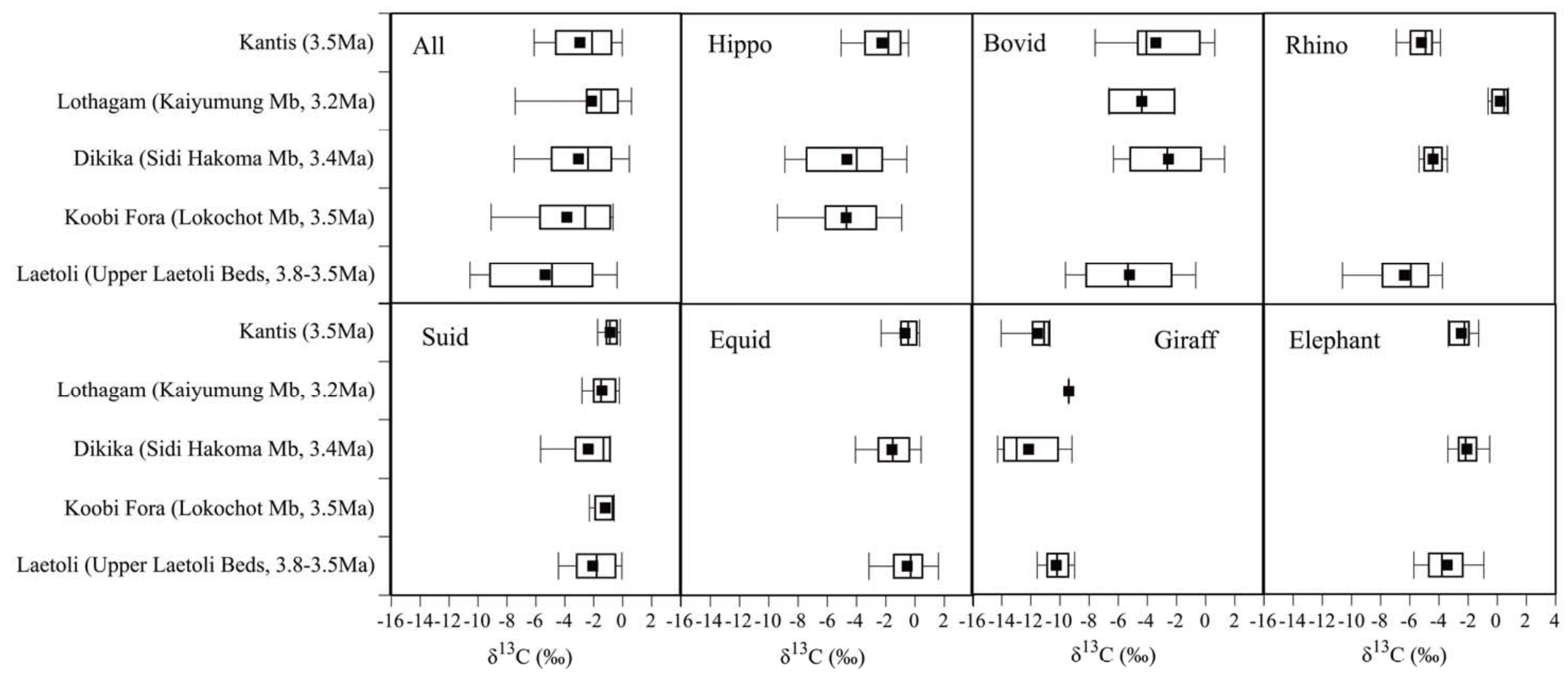


Table 1. Summary of radiometric ages and magnetostratigraphy of the Kantis Basalt, fossiliferous beds, and Lower Kerichwa Tuff at KFS.

\begin{tabular}{|c|c|c|c|}
\hline Stratigraphy & Radiometric age & $\begin{array}{l}\text { Magnetic } \\
\text { polarity }\end{array}$ & $\begin{array}{l}\text { Geomagnetic polarity time } \\
\text { scale }^{\mathrm{a}}\end{array}$ \\
\hline $\begin{array}{l}\text { Lower Kerichwa Tuff } \\
\text { (trachyte pyroclastic } \\
\text { flow deposits) }\end{array}$ & $\begin{array}{l}{ }^{40} \mathrm{Ar} /{ }^{39} \mathrm{Ar} \text { age of sanidine: } \\
2.77 \pm 0.01 \mathrm{Ma}\end{array}$ & Normal & C2An.1n: 2.581-3.032 Ma \\
\hline \multicolumn{4}{|l|}{ Unconformity } \\
\hline $\begin{array}{l}\text { Kantis fossiliferous } \\
\text { beds }\end{array}$ & $\begin{array}{l}\text { Zircon U-Pb ages } \\
\text { volcanic mud flow: } 3.4 \pm 0.1 \mathrm{Ma} \\
\text { Kantis tuff: } 3.5 \pm 0.1 \mathrm{Ma}\end{array}$ & Normal & C2An.3n: 3.330-3.596Ma \\
\hline \multicolumn{4}{|l|}{ Unconformity } \\
\hline $\begin{array}{l}\text { Kantis Basalt } \\
\text { (picrobasalt lava flow) }\end{array}$ & $\begin{array}{l}{ }^{40} \mathrm{Ar} /{ }^{39} \mathrm{Ar} \text { ages of groundmass: } \\
5.30 \pm 0.02 \mathrm{Ma} ; 5.28 \pm 0.05 \mathrm{Ma}\end{array}$ & Normal & \\
\hline
\end{tabular}

${ }^{\mathrm{a} O g g}$ (2012). 
Table 2. KFS fauna list, with the number of identified specimens in each taxon $(N)$, dietary preferences (Diet), and locomotor adaptations (Loc).

\begin{tabular}{|c|c|c|c|c|c|c|}
\hline Order & Family & Tribe & Species & $N$ & $\operatorname{Diet}^{\mathrm{a}}$ & $\operatorname{Loc}^{b}$ \\
\hline \multicolumn{7}{|c|}{ Primates } \\
\hline & Hominidae & Hominini & Australopithecus afarensis & 4 & $\mathrm{OM}$ & $\mathrm{T}$ \\
\hline \multirow{2}{*}{\multicolumn{2}{|c|}{ Cercopithecidae }} & Papionini & gen. et sp. indet. & 66 & FL & TA \\
\hline & & Colobini & gen. et sp. indet. (large) & 7 & FL & TA \\
\hline \multicolumn{7}{|c|}{ Carnivora } \\
\hline & Mustelidae & Enhydriodontini & Enhydriodon sp. & 1 & $\mathrm{CI}$ & $\mathrm{AQ}$ \\
\hline & Felidae & Homotheriini & Homotherium sp & 1 & $\mathrm{C}$ & $\mathrm{T}$ \\
\hline & Hyaenidae & & Crocuta sp. & 1 & $\mathrm{CB}$ & $\mathrm{T}$ \\
\hline & Herpestidae & & Cf. Ichneumia sp. & 1 & $\mathrm{CI}$ & $\mathrm{T}$ \\
\hline & & & Cf. Mungos sp. & 1 & $\mathrm{CI}$ & $\mathrm{T}$ \\
\hline \multicolumn{7}{|c|}{ Proboscidea } \\
\hline & Elephantidae & & gen. et sp. indet & 6 & MF & $\mathrm{T}$ \\
\hline \multicolumn{7}{|c|}{ Cetartiodactyla } \\
\hline \multirow{2}{*}{\multicolumn{2}{|c|}{ Hippopotamidae }} & & aff. Hippo. cf. protamphibius & 310 & FG & $\mathrm{AQ}$ \\
\hline & & & Gen. et sp. indet. & 1 & FG & $\mathrm{AQ}$ \\
\hline \multirow{3}{*}{\multicolumn{2}{|c|}{ Suidae }} & & & 67 & & \\
\hline & & & Notochoerus euilus & 43 & $\mathrm{G}$ & $\mathrm{T}$ \\
\hline & & & Kolpochoerus sp.? & 3 & OM & $\mathrm{T}$ \\
\hline & Giraffidae & & Sivatherium sp. & 13 & $\mathrm{~B}$ & $\mathrm{~T}$ \\
\hline \multirow{12}{*}{\multicolumn{2}{|c|}{ Bovidae }} & & & 183 & & \\
\hline & & Tragelaphini & Gen. et sp. indet. & 3 & B & $\mathrm{T}$ \\
\hline & & Bovini & cf. Ugandax sp. & 25 & MF & $\mathrm{T}$ \\
\hline & & Alcelaphini & & 52 & & \\
\hline & & & cf. Damaliscus sp. nov. & 3 & $\mathrm{G}$ & $\mathrm{T}$ \\
\hline & & & gen. et sp. indet. (small) & 4 & $\mathrm{G}$ & $\mathrm{T}$ \\
\hline & & Hippotragini & & 12 & & \\
\hline & & & Oryx cf. deturi & 6 & $\mathrm{G}$ & $\mathrm{T}$ \\
\hline & & Reduncini & Kobus sp. & 1 & FG & $\mathrm{T}$ \\
\hline & & Aepycerotini & Aepyceros aff. dietrichi & 32 & MF & $\mathrm{T}$ \\
\hline & & Cephalophini & Cephalophus sp. & 2 & $\mathrm{~B}$ & $\mathrm{~T}$ \\
\hline & & Antilopini & Gazella sp. & 12 & MF & $\mathrm{T}$ \\
\hline \multicolumn{7}{|c|}{ Perissodactyla } \\
\hline \multirow{2}{*}{\multicolumn{2}{|c|}{ Rhinocerotidae }} & Dicerotini & Ceratotherium mauritanicum & 36 & $\mathrm{G}$ & $\mathrm{T}$ \\
\hline & & & Diceros sp. & 2 & $\mathrm{~B}$ & $\mathrm{~T}$ \\
\hline & Equidae & & Hipparion s.1. sp. & 39 & $\mathrm{G}$ & $\mathrm{T}$ \\
\hline \multicolumn{7}{|c|}{ Rodentia } \\
\hline & Thryonomyidae & & Thryonomys sp. & 1 & $\mathrm{FG}$ & $\mathrm{T}$ \\
\hline Aves & & & Gen. et sp. indet. & & & \\
\hline \multicolumn{7}{|c|}{ Crocodylia } \\
\hline & Crocodylidae & & Gen. et. sp. indet. & & & \\
\hline
\end{tabular}


aDietary preferences. $\mathrm{OM}=$ omnivores. $\mathrm{FL}=$ fruit and leaf eaters. $\mathrm{CI}=$ carnivores (meat and invertebrates). $\mathrm{C}=$ carnivores (meat only). $\mathrm{CB}=$ carnivores (meat and bone). $\mathrm{MF}=$ mixed feeders (browse and graze). $\mathrm{FG}=$ fresh-grass grazers. $\mathrm{G}=$ grazers. $\mathrm{B}=$ browsers.

${ }^{b}$ Locomotor adaptations. $\mathrm{T}=$ terrestrial. $\mathrm{TA}=$ terrestrial and arboreal. $\mathrm{AQ}=$ aquatic. 
Table 3. Comparative dp3 and UC measurements and index: Mesiodistal (MD) and Buccolingual (BL) diameters.

\begin{tabular}{|c|c|c|c|c|}
\hline dp3 & $\mathrm{MD}(\mathrm{mm})$ & $\mathrm{BL}(\mathrm{mm})$ & BL/MD (\%) & Source \\
\hline \multicolumn{5}{|l|}{ Kantis } \\
\hline KNM-RK 53001 & 8.7 & 6.9 & 79.3 & \\
\hline KNM-RK 53000 & 8.6 & 7.1 & 82.6 & \\
\hline \multicolumn{5}{|l|}{ Au. anamensis } \\
\hline KNM-KP 34725 & 8.9 & 6.8 & 76.4 & \\
\hline Au. afarensis & & & & White et al. (1994) \\
\hline$N$ & 4 & 4 & 4 & \\
\hline Mean & 9.2 & 7.9 & 86.8 & \\
\hline Range & $8.5-9.6$ & $7.6-8.4$ & 81.9-94.1 & \\
\hline s.d. & 0.5 & 0.4 & 5.4 & \\
\hline Au. africanus & & & & White et al. (1994) \\
\hline$N$ & 7 & 5 & & \\
\hline Mean & 8.8 & 7.6 & $86.4^{\mathrm{a}}$ & \\
\hline Range & $8.4-9.1$ & $7.1-8.1$ & NA & \\
\hline s.d. & 0.2 & 0.4 & NA & \\
\hline P. robustus & & & & White et al. (1994) \\
\hline$N$ & 8 & 8 & & \\
\hline Mean & 10.1 & 8.3 & $82.2^{\mathrm{a}}$ & \\
\hline Range & $9-10.8$ & $7.7-9.7$ & NA & \\
\hline s.d. & 0.5 & 0.6 & NA & \\
\hline Ar. ramidus & & & & White et al. (1994) \\
\hline ARA-VP-1/129 & 7.3 & 4.9 & 67.1 & \\
\hline $\mathbf{U C}$ & $\mathrm{MD}$ & $\mathrm{BL}$ & & \\
\hline \multicolumn{5}{|l|}{ Kantis } \\
\hline KNM-RK 53800 & 11.5 & 11.6 & & \\
\hline Au. anamensis & & & & Ward et al. (2010) \\
\hline$N$ & 8 & 7 & & \\
\hline Mean & 11.1 & 10.2 & & \\
\hline Range & $9.9-12.4$ & $8.8-11.2$ & & \\
\hline s.d. & 0.82 & 0.75 & & \\
\hline Au. afarensis & & & & Ward et al. (2010) \\
\hline
\end{tabular}




$\begin{array}{lll}N & 8 & 8 \\ \text { Mean } & 9.8 & 10.7 \\ \text { Range } & 8.9-11.6 & 9.3-12.5 \\ \text { s.d. } & 0.84 & 1.00\end{array}$

Au. africanus

Moggi-Cecchi et al.

(2006)

White et al. (1994)

$\begin{array}{lll}N & 13 & 13 \\ \text { Mean } & 10.1 & 10.6 \\ \text { Range } & 8.8-11.1 & 8.9-12.7 \\ \text { s.d. } & 0.76 & 1.29\end{array}$

Ar. ramidus

$\begin{array}{lll}\text { ARA-VP-1/300 } & 11.2 & 11.1\end{array}$

$\begin{array}{lll}\text { ARA-VP-6/1 } & 11.5 & 11.7\end{array}$

${ }^{\mathrm{a}}$ Calculated from averages of BL and MD. 
Table 4. Measurements on hominin ulna. ${ }^{a}$

\begin{tabular}{|c|c|c|c|c|c|c|c|}
\hline Specimen & Taxon & $\begin{array}{l}\text { Age } \\
(\mathrm{Ma})\end{array}$ & UTW & UPC & UCP & USM & UKN \\
\hline KNM-RK & Au. afarensis & 3.5 & 11.5 & 16.5 & $(>29.5)$ & $(>19.3)$ & 136 \\
\hline \multicolumn{8}{|l|}{53525} \\
\hline A.L. $438-1$ & Au. afarensis & 3.0 & 11.4 & 16.2 & 31.8 & 19.6 & 131 \\
\hline \multirow[t]{2}{*}{ A.L. 288-1 } & Au. afarensis & 3.4 & 12.3 & 12.4 & 22.5 & 15.2 & $132 / 13$ \\
\hline & & & & & & & $0^{\mathrm{c}}$ \\
\hline KSD-VP-1-1a & Au. afarensis & 3.6 & - & - & - & - & 126 \\
\hline L40-19 & hominini indet. & 2.3 & 17.3 & 20.8 & 33.4 & 23.9 & 121 \\
\hline \multirow[t]{2}{*}{ OH 36} & cf.Paranthropus & 1.2 & 15.8 & 23.6 & 36.1 & 18.1 & 102 \\
\hline & boisei $^{2}$ & & & & & & \\
\hline UW-88-62 & Au. sediba & 2.0 & 12.6 & 15.7 & 25.5 & 15.1 & 128 \\
\hline
\end{tabular}

${ }^{\mathrm{a}}$ Comparative metrics are adapted from Drapeau et al. (2005), except for KSD-VP-1-1a (from Haile-Selassie et al., 2010) and UW-88-62 (taken from cast at NMK).

Abbreviations: UTW $=$ Mediolateral breadth of middle portion of the articular surface of the trochlear notch, UPC $=$ Distance from posterior margin of ulna to the maximum depth of the keel of the trochlear notch, USM = Mediolateral breadth of the diaphysis immediately below radial notch, UKN = Keeling of trochlear notch measured as the angle between the articular surfaces of the trochlear notch on each side of the keel on the proximal part of the trochlear notch.

${ }^{\mathrm{b}}$ Taxonomic assignment by Aiello et al. (1999).

${ }^{\mathrm{c}}$ Right (A.L. 288-1n) and left ulnae (A.L. 288-1t). 
Table 5. Isotopic analyses of enamel from fossil mammals at KFS, Lothagam (Kaiyumung Mb; 3.2 Ma), Laetoli (Upper Laetoli Beds; 3.8-3.5 Ma), Dikika (SidiHakoma Mb; 3.4 Ma), and Koobi Fora (Lokochot Mb; 3.5 Ma). For individual data, see SOM Table S6.

\begin{tabular}{llrlll}
\hline Taxon & Ste & $N$ & Mean & S.D. & Reference \\
\hline All & Kantis & 127 & -3.2 & 3.1 & \\
& Lothagam & 12 & -2.2 & 3.0 & Uno et al. (2011) \\
& Laetoli & 239 & -5.4 & 3.9 & Kingston (2011) \\
& Dikika & 131 & -3.1 & 3.4 & Bedaso et al. (2013) \\
& KoobiFora & 13 & -3.9 & 3.1 & Harris and Cerling (2002), \\
& & & & & Harris et al. (2008)
\end{tabular}

Hippopotamidae

$\begin{array}{lcccl}\text { Kantis } & 30 & -2.5 & 2.4 & \\ \text { Dikika } & 11 & -4.6 & 3.2 & \text { Bedaso et al. (2013) } \\ \text { KoobiFora } & 10 & -4.7 & 3.1 & \text { Harris et al. (2008) }\end{array}$

Bovidae

$\begin{array}{lrrrl}\text { Kantis } & 15 & -3.3 & 3.5 & \\ \text { Lothagam } & 2 & -4.4 & 3.2 & \text { Uno et al. (2011) } \\ \text { Laetoli } & 87 & -5.2 & 3.5 & \text { Kingston (2011) } \\ \text { Dikika } & 57 & -2.5 & 2.9 & \text { Bedaso et al. (2013) }\end{array}$

(Alcelaphini only)

$\begin{array}{lrrrl}\text { Kantis } & 8 & -1.1 & 2.5 & \\ \text { Laetoli } & 33 & -2.4 & 2.4 & \text { Kingston (2011) } \\ \text { Dikika } & 20 & -0.1 & 2.0 & \text { Bedaso et al. (2013) }\end{array}$

Suidae

$\begin{array}{lrrrl}\text { Kantis } & 24 & -0.9 & 0.6 & \\ \text { Lothagam } & 6 & -1.4 & 1.0 & \text { Uno et al. (2011) } \\ \text { Laetoli } & 36 & -1.9 & 1.9 & \text { Kingston (2011) } \\ \text { Dikika } & 9 & -2.4 & 2.1 & \text { Bedaso et al. (2013) } \\ \text { KoobiFora } & 3 & -1.2 & 1.0 & \text { Harris and Cerling (2002) }\end{array}$


Giraffidae

$\begin{array}{lrrll}\text { Kantis } & 6 & -11.3 & 1.4 & \\ \text { Lothagam } & 1 & -9.4 & - & \text { Uno et al. (2011) } \\ \text { Laetoli } & 47 & -10.3 & 1.1 & \text { Kingston (2011) } \\ \text { Dikika } & 8 & -12.2 & 2.1 & \text { Bedaso et al. (2013) }\end{array}$

Rhinocerotidae

$\begin{array}{lrrrl}\text { Kantis } & 29 & -5.3 & 1.7 & \\ \text { Lothagam } & 3 & 0.2 & 0.7 & \text { Uno et al. (2011) } \\ \text { Laetoli } & 30 & -6.4 & 2.5 & \text { Kingston (2011) } \\ \text { Dikika } & 4 & -4.4 & 0.8 & \text { Bedaso et al. (2013) }\end{array}$

Equidae

$\begin{array}{lllll}\text { Kantis } & 17 & -0.9 & 1.3 & \\ \text { Laetoli } & 18 & -1.0 & 1.9 & \text { Kingston (2011) } \\ \text { Dikika } & 32 & -1.6 & 1.5 & \text { Bedaso et al. (2013) }\end{array}$

Elephantidae

$\begin{array}{lrrrl}\text { Kantis } & 6 & -2.9 & 1.4 & \\ \text { Laetoli } & 21 & -3.4 & 1.8 & \text { Kingston (2011) } \\ \text { Dikika } & 10 & -2.1 & 1.0 & \text { Bedaso et al. (2013) }\end{array}$


SOM Table S1. Assemblage and chemical compositions of minerals (a) and chemical composition of the volcanic glass (b) in tuff and matrix of mud flow deposit, and pyroclastic flow deposit from KFS.

\begin{tabular}{|c|c|c|c|c|c|c|}
\hline & KY13011903 & Kantis Tuff & \multicolumn{2}{|c|}{ Volcanic mud flow } & \multicolumn{2}{|c|}{$\begin{array}{l}\text { Lower Kerichwa Tuff pyroclastic } \\
\text { flow }\end{array}$} \\
\hline (a) & & & & & & \\
\hline Feldspar & \multirow{2}{*}{\multicolumn{2}{|c|}{$1.4 \sim 1.1$}} & \multirow{2}{*}{\multicolumn{2}{|c|}{$1.8 \sim 0.4$}} & & \\
\hline $\mathrm{Ca}(\mathrm{An})$ & & & & & \multicolumn{2}{|c|}{$3.8 \sim 0.9$} \\
\hline $\mathrm{Na}(\mathrm{Ab})$ & \multicolumn{2}{|c|}{$61.6 \sim 61.5$} & \multicolumn{2}{|c|}{$66.3 \sim 60.9$} & \multicolumn{2}{|c|}{$72.8 \sim 66.2$} \\
\hline $\mathrm{K}(\mathrm{Or})$ & \multicolumn{2}{|c|}{$37.4 \sim 37.0$} & \multicolumn{2}{|c|}{$37.4 \sim 33.2$} & \multicolumn{2}{|c|}{$32.9 \sim 27.7$} \\
\hline $\begin{array}{l}\text { Clinopyroxene } \\
\text { (wt \%) }\end{array}$ & & & & & (A) & $(B)^{1}$ \\
\hline $\mathrm{TiO}_{2}$ & \multicolumn{2}{|c|}{$3.36 \sim 1.55$} & \multicolumn{2}{|c|}{$4.02 \sim 1.83$} & $3.17 \sim 1.76$ & $0.56 \sim 0.50$ \\
\hline $\mathrm{Al}_{2} \mathrm{O}_{3}$ & \multicolumn{2}{|c|}{$7.13 \sim 5.04$} & \multicolumn{2}{|c|}{$9.79 \sim 5.81$} & $7.40 \sim 5.04$ & $0.67 \sim 0.56$ \\
\hline $\begin{array}{l}\mathrm{Na}_{2} \mathrm{O} \\
\text { (atomic ratio) }\end{array}$ & \multicolumn{2}{|c|}{$0.57 \sim 0.37$} & \multicolumn{2}{|c|}{$0.79 \sim 0.51$} & \multicolumn{2}{|l|}{$0.87 \sim 0.49$} \\
\hline $\mathrm{Fe}$ & \multicolumn{2}{|c|}{$12.2 \sim 9.8$} & \multicolumn{2}{|c|}{$15.4 \sim 10.3$} & $13.7 \sim 11.3$ & $25.7 \sim 23.3$ \\
\hline $\mathrm{Mg}$ & \multicolumn{2}{|c|}{$41.9 \sim 37.5$} & \multicolumn{2}{|c|}{$40.7 \sim 33.6$} & $39.4 \sim 37.5$ & $36.5 \sim 32.0$ \\
\hline $\mathrm{Ca}$ & \multicolumn{2}{|c|}{$50.3 \sim 48.0$} & \multicolumn{2}{|c|}{$51.5 \sim 48.6$} & $50.1 \sim 48.0$ & $42.4 \sim 39.6$ \\
\hline mg-value & \multicolumn{2}{|c|}{$81.1 \sim 75.4$} & \multicolumn{2}{|c|}{$79.7 \sim 69.1$} & $77.0 \sim 73.7$ & $60.4 \sim 55.5$ \\
\hline \multicolumn{7}{|l|}{$\begin{array}{l}\text { Amphibole } \\
\text { (kaersutite) }\end{array}$} \\
\hline $\mathrm{TiO}_{2}$ (wt \%) & \multicolumn{2}{|c|}{$5.82 \sim 4.37$} & \multicolumn{2}{|c|}{$5.74 \sim 5.02$} & \multicolumn{2}{|c|}{$5.45 \sim 5.22$} \\
\hline mg-value & \multicolumn{2}{|c|}{$71.4 \sim 63.0$} & 71. & 6.8 & 71 & 0.7 \\
\hline Others & $\begin{array}{r}\text { titan } \\
\text { mag } \\
\text { IIm } \\
\text { Ap } \\
\mathrm{Zi}\end{array}$ & & & $\begin{array}{l}\text { ous } \\
\text { tite } \\
\text { te } \\
\text { te } \\
\text { n }\end{array}$ & titanifero & $\begin{array}{l}\text { nagnetite } \\
\text { te } \\
\text { e } \\
\text { n }\end{array}$ \\
\hline (b) & $\begin{array}{l}\text { mean } \\
(\mathrm{n}=7)\end{array}$ & s.d. & $\begin{array}{l}\text { mean } \\
(\mathrm{n}=10)\end{array}$ & s.d. & $\begin{array}{l}\text { mean } \\
(n=13)\end{array}$ & s.d. \\
\hline $\mathrm{SiO}_{2}$ & $65.04^{2}$ & 0.37 & 65.41 & 0.26 & 64.48 & 0.24 \\
\hline $\mathrm{TiO}_{2}$ & 0.82 & 0.06 & 0.81 & 0.06 & 0.76 & 0.08 \\
\hline $\mathrm{Al}_{2} \mathrm{O}_{3}$ & 14.55 & 0.39 & 14.63 & 0.17 & 14.19 & 0.24 \\
\hline
\end{tabular}




\begin{tabular}{|l|ll|ll|ll|}
$\mathrm{FeO}$ & 5.96 & 0.12 & 5.87 & 0.14 & 6.61 & 0.10 \\
$\mathrm{MnO}$ & 0.31 & 0.05 & 0.27 & 0.04 & 0.33 & 0.05 \\
$\mathrm{MgO}$ & 0.58 & 0.03 & 0.54 & 0.04 & 0.50 & 0.03 \\
$\mathrm{CaO}$ & 0.88 & 0.05 & 0.88 & 0.04 & 0.84 & 0.05 \\
$\mathrm{Na} 2 \mathrm{O}$ & 6.47 & 0.14 & 6.26 & 0.12 & 7.43 & 0.29 \\
$\mathrm{~K} 2 \mathrm{O}$ & 5.25 & 0.10 & 5.20 & 0.13 & 4.75 & 0.10 \\
$\mathrm{P}_{2} \mathrm{O}_{5}$ & 0.14 & 0.01 & 0.14 & 0.04 & 0.12 & 0.03 \\
\hline
\end{tabular}

${ }^{1}$ There are compositionally different groups of clinopyroxene, (A) and (B), in KY13012201. ${ }^{2} \mathrm{Wt} \%$. Composition is volatile free. 
SOM Table S2. ${ }^{40} \mathrm{Ar} /{ }^{39} \mathrm{Ar}$ data on sample K09-686, Lower Kerichwa Tuff (a), K11-771, Alkali basalt clast at KFS (b) and K09-620, Kantis Basalt at KFS (c).

\begin{tabular}{|c|c|c|c|c|c|c|c|c|c|c|c|c|c|}
\hline $\begin{array}{l}\text { Incremental } \\
\text { Heating }\end{array}$ & & & ${ }^{36} \operatorname{Ar}(a)$ & ${ }^{37} \operatorname{Ar}(\mathrm{ca})$ & ${ }^{38} \mathrm{Ar}(\mathrm{cl})$ & ${ }^{39} \operatorname{Ar}(\mathrm{k})$ & ${ }^{40} \operatorname{Ar}(r)$ & Age & $\begin{array}{l} \pm 2 \sigma \\
\mathrm{Ma})\end{array}$ & $\begin{array}{c}{ }^{40} \mathrm{Ar}(\mathrm{r}) \\
(\%)\end{array}$ & $\begin{array}{c}{ }^{39} \operatorname{Ar}(\mathrm{k}) \\
(\%)\end{array}$ & $\mathrm{K} / \mathrm{Ca}$ & $\pm 2 \sigma$ \\
\hline BG7332 & $35.0 \%$ & $v$ & 0.000643 & 0.011028 & 0.000000 & 0.620849 & 0.969441 & 2.77 & \pm 0.01 & 83.60 & 15.34 & 24.208 & \pm 0.489 \\
\hline BG7333 & $35.0 \%$ & $v$ & 0.000084 & 0.001131 & 0.000000 & 0.141066 & 0.220942 & 2.78 & \pm 0.04 & 89.94 & 3.49 & 53.653 & \pm 2.255 \\
\hline BG7335 & $35.0 \%$ & $v$ & 0.000359 & 0.002570 & 0.000000 & 0.183491 & 0.287813 & 2.78 & \pm 0.03 & 73.07 & 4.53 & 30.699 & \pm 0.640 \\
\hline BG7336 & $35.0 \%$ & $v$ & 0.001565 & 0.017680 & 0.000000 & 0.555518 & 0.865048 & 2.76 & \pm 0.01 & 65.17 & 13.72 & 13.511 & \pm 0.233 \\
\hline BG7338 & $35.0 \%$ & $v$ & 0.000189 & 0.005269 & 0.000111 & 0.298081 & 0.465829 & 2.77 & \pm 0.02 & 89.30 & 7.36 & 24.327 & \pm 0.592 \\
\hline BG7339 & $35.0 \%$ & $r$ & 0.000060 & 0.006709 & 0.000000 & 0.239465 & 0.373268 & 2.77 & \pm 0.02 & 95.43 & 5.92 & 15.349 & \pm 0.344 \\
\hline BG7341 & $35.0 \%$ & $v$ & 0.000126 & 0.008170 & 0.000000 & 0.190223 & 0.298774 & 2.79 & \pm 0.03 & 88.89 & 4.70 & 10.011 & \pm 0.251 \\
\hline BG7342 & $35.0 \%$ & $v$ & 0.000026 & 0.001942 & 0.000000 & 0.126134 & 0.198480 & 2.79 & \pm 0.03 & 96.34 & 3.12 & 27.934 & \pm 1.090 \\
\hline BG7344 & $35.0 \%$ & $v$ & 0.000121 & 0.005251 & 0.000074 & 0.227076 & 0.354517 & 2.77 & \pm 0.03 & 90.83 & 5.61 & 18.595 & \pm 0.385 \\
\hline BG7345 & $35.0 \%$ & $v$ & 0.000067 & 0.004056 & 0.000049 & 0.179543 & 0.282275 & 2.79 & \pm 0.03 & 93.44 & 4.44 & 19.034 & \pm 0.433 \\
\hline BG7347 & $35.0 \%$ & 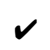 & 0.000206 & 0.003320 & 0.000012 & 0.212776 & 0.331333 & 2.76 & \pm 0.02 & 84.48 & 5.26 & 27.557 & \pm 0.775 \\
\hline BG7348 & $35.0 \%$ & $v$ & 0.000081 & 0.004233 & 0.000036 & 0.219706 & 0.344602 & 2.78 & \pm 0.03 & 93.52 & 5.43 & 22.318 & \pm 0.509 \\
\hline BG7350 & $35.0 \%$ & $v$ & 0.000139 & 0.004540 & 0.000000 & 0.166472 & 0.260039 & 2.77 & \pm 0.03 & 86.35 & 4.11 & 15.767 & \pm 0.465 \\
\hline BG7351 & $35.0 \%$ & $\checkmark$ & 0.000043 & 0.002117 & 0.000085 & 0.186268 & 0.289853 & 2.76 & \pm 0.04 & 95.78 & 4.60 & 37.842 & \pm 1.281 \\
\hline BG7353 & $35.0 \%$ & $v$ & 0.000053 & 0.001729 & 0.000038 & 0.093587 & 0.145517 & 2.76 & \pm 0.06 & 90.32 & 2.31 & 23.277 & \pm 1.043 \\
\hline BG7354 & $35.0 \%$ & 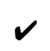 & 0.000378 & 0.005052 & 0.000000 & 0.184707 & 0.288397 & 2.77 & \pm 0.03 & 72.08 & 4.56 & 15.723 & \pm 0.430 \\
\hline \multirow[t]{2}{*}{ BG7356 } & $35.0 \%$ & $v$ & 0.000612 & 0.004876 & 0.000000 & 0.222840 & 0.346979 & 2.76 & \pm 0.04 & 65.74 & 5.51 & 19.650 & \pm 0.499 \\
\hline & & $\Sigma$ & 0.004752 & 0.089672 & 0.000406 & 4.047802 & 6.323106 & & & & & & \\
\hline \multicolumn{3}{|l|}{$\begin{array}{l}\text { Information } \\
\text { on Analysis }\end{array}$} & & \multicolumn{2}{|c|}{ Results } & $\begin{array}{l}{ }^{40} \mathrm{Ar}(\mathrm{r}) / \\
{ }^{39} \mathrm{Ar}(\mathrm{k})\end{array}$ & $\pm 2 \sigma$ & Age & $\begin{array}{l} \pm 2 \sigma \\
\mathrm{Ma})\end{array}$ & $\sum_{\substack{\infty \\
\Sigma}}^{0}$ & $\begin{array}{c}{ }^{39} \mathrm{Ar}(\mathrm{k}) \\
(\%, \mathrm{n})\end{array}$ & $\mathrm{K} / \mathrm{Ca}$ & $\pm 2 \sigma$ \\
\hline \multicolumn{3}{|l|}{ K09-686 } & & \multicolumn{2}{|c|}{ Weighted Plateau } & 1.5618 & \pm 0.0032 & 2.77 & \pm 0.01 & 0.51 & 100.00 & 16.864 & \pm 2.891 \\
\hline \multicolumn{3}{|l|}{ Sanidine } & & & & & $\pm 0.20 \%$ & & $\pm 0.32 \%$ & & 17 & & \\
\hline \multicolumn{3}{|l|}{110} & & & & & \multicolumn{2}{|c|}{ External Error } & \pm 0.11 & 2.12 & \multicolumn{2}{|c|}{ Statistical T Ratio } & \\
\hline \multicolumn{3}{|l|}{ LAS } & & & & & \multicolumn{2}{|c|}{ Analytical Error } & \pm 0.01 & 1.0000 & Error Magr & cation & \\
\hline \multicolumn{2}{|c|}{ Project $=$ UW91E } & & & \multicolumn{2}{|c|}{ Total Fusion Age } & 1.5621 & \pm 0.0035 & 2.77 & \pm 0.01 & & 17 & 0.544 & \pm 0.004 \\
\hline \multicolumn{2}{|c|}{ Irradiation = UW91 } & & & & & & $\pm 0.22 \%$ & & $\pm 0.33 \%$ & & & & \\
\hline \multicolumn{3}{|c|}{$J=0.0009706 \pm 0.0000012$} & & & & & \multicolumn{2}{|c|}{ External Error } & \pm 0.11 & & & & \\
\hline \multicolumn{3}{|c|}{$\mathrm{FCs}=28.201 \pm 0.023 \mathrm{Ma}$} & & & & & \multicolumn{2}{|c|}{ Analytical Error } & \pm 0.01 & & & & \\
\hline
\end{tabular}

(b) 


\begin{tabular}{|c|c|c|c|c|c|c|c|c|c|c|c|c|c|}
\hline \multirow[t]{2}{*}{$\begin{array}{l}\text { Incremental } \\
\text { Heating }\end{array}$} & & & ${ }^{36} \operatorname{Ar}(\mathrm{a})$ & ${ }^{37} \operatorname{Ar}(\mathrm{ca})$ & ${ }^{38} \mathrm{Ar}(\mathrm{cl})$ & ${ }^{39} \operatorname{Ar}(\mathrm{k})$ & ${ }^{40} \mathrm{Ar}(\mathrm{r})$ & Age & $\pm 2 \sigma$ & \multirow{2}{*}{$\begin{array}{c}{ }^{40} \mathrm{Ar}(\mathrm{r}) \\
(\%)\end{array}$} & \multirow{2}{*}{$\begin{array}{c}{ }^{39} \operatorname{Ar}(\mathrm{k}) \\
(\%)\end{array}$} & \multirow[t]{2}{*}{$\mathrm{K} / \mathrm{Ca}$} & \multirow[t]{2}{*}{ $\pm 2 \sigma$} \\
\hline & & & {$[\mathrm{V}]$} & [V] & [V] & [V] & [V] & \multicolumn{2}{|c|}{$(\mathrm{Ma})$} & & & & \\
\hline CA0740 & $695^{\circ} \mathrm{C}$ & $\checkmark$ & 0.0005427 & 0.012080 & 0.0000825 & 0.0174915 & 0.0412475 & 5.38 & \pm 0.58 & 20.46 & 0.40 & 0.623 & \pm 0.057 \\
\hline CA0741 & $740^{\circ} \mathrm{C}$ & $\checkmark$ & 0.0012403 & 0.061809 & 0.0004306 & 0.0901344 & 0.2119148 & 5.37 & \pm 0.15 & 36.64 & 2.07 & 0.627 & \pm 0.039 \\
\hline CA0742 & $790^{\circ} \mathrm{C}$ & $\checkmark$ & 0.0004773 & 0.151715 & 0.0005788 & 0.2200905 & 0.5133893 & 5.33 & \pm 0.05 & 78.45 & 5.06 & 0.624 & \pm 0.036 \\
\hline CA0743 & $835^{\circ} \mathrm{C}$ & $\checkmark$ & 0.0005136 & 0.336931 & 0.0002987 & 0.5180713 & 1.2055675 & 5.31 & \pm 0.02 & 88.82 & 11.90 & 0.661 & \pm 0.038 \\
\hline CA0744 & $885^{\circ} \mathrm{C}$ & $\checkmark$ & 0.0004032 & 0.401806 & 0.0000614 & 0.5639796 & 1.3110802 & 5.31 & \pm 0.03 & 91.67 & 12.96 & 0.604 & \pm 0.034 \\
\hline CA0745 & $950^{\circ} \mathrm{C}$ & $\checkmark$ & 0.0006173 & 0.515683 & 0.0000000 & 0.5348873 & 1.2383532 & 5.29 & \pm 0.03 & 87.16 & 12.29 & 0.446 & \pm 0.025 \\
\hline CA0746 & $1020^{\circ} \mathrm{C}$ & $\checkmark$ & 0.0006740 & 0.536760 & 0.0000000 & 0.4009327 & 0.9275084 & 5.28 & \pm 0.03 & 82.32 & 9.21 & 0.321 & \pm 0.018 \\
\hline CA0747 & $1100^{\circ} \mathrm{C}$ & & 0.0012317 & 1.408092 & 0.0003352 & 0.4342007 & 0.9832344 & 5.17 & \pm 0.08 & 72.98 & 9.97 & 0.133 & \pm 0.008 \\
\hline CA0748 & $1180^{\circ} \mathrm{C}$ & & 0.0031310 & 8.196025 & 0.0010479 & 1.0040131 & 2.2234480 & 5.06 & \pm 0.09 & 70.62 & 23.06 & 0.053 & \pm 0.003 \\
\hline \multirow[t]{2}{*}{ CA0749 } & $1250^{\circ} \mathrm{C}$ & & 0.0018989 & 7.130130 & 0.0005333 & 0.5692779 & 1.2876273 & 5.16 & \pm 0.15 & 69.65 & 13.08 & 0.034 & \pm 0.002 \\
\hline & & $\Sigma$ & 0.0107301 & 18.751029 & 0.0033683 & 4.3530790 & 9.9433707 & & & & & & \\
\hline \multicolumn{3}{|l|}{$\begin{array}{l}\text { Information } \\
\text { on Analysis }\end{array}$} & & \multicolumn{2}{|c|}{ Results } & $\begin{array}{l}{ }^{40} \mathrm{Ar}(\mathrm{r}) / \\
{ }^{39} \mathrm{Ar}(\mathrm{k})\end{array}$ & $\pm 2 \sigma$ & Age & $\begin{array}{l} \pm 2 \sigma \\
M a)\end{array}$ & $\frac{D}{\sum}$ & $\begin{array}{c}{ }^{39} \operatorname{Ar}(\mathrm{k}) \\
(\%, \mathrm{n})\end{array}$ & $\mathrm{K} / \mathrm{Ca}$ & $\pm 2 \sigma$ \\
\hline \multicolumn{3}{|c|}{ Sample $=\mathrm{K} 11-771$} & & \multicolumn{2}{|l|}{ Age Plateau } & 2.32218 & \pm 0.00574 & 5.30 & \pm 0.01 & 0.91 & 53.88 & 0.474 & \pm 0.113 \\
\hline \multicolumn{3}{|c|}{ Material $=$ groundmass } & & & & & \multicolumn{2}{|l|}{ $\pm 0.25 \%$} & $\pm 0.27 \%$ & $48 \%$ & 7 & & \\
\hline \multicolumn{3}{|c|}{ Location $=$ UW103C17 } & & & & & \multicolumn{2}{|c|}{ Minimal External Error } & \pm 0.21 & 2.15 & \multicolumn{2}{|c|}{$2 \sigma$ Confidence Limit } & \\
\hline \multicolumn{3}{|c|}{ Analyst $=$ Jicha, Brian } & & & & & \multirow{2}{*}{\multicolumn{2}{|c|}{ Analytical Error }} & \pm 0.01 & 1.0000 & \multicolumn{2}{|c|}{ Error Magnification } & \\
\hline \multicolumn{3}{|c|}{ Project $=$ UW103C } & & & & & & & & & & & \\
\hline \multicolumn{3}{|c|}{$\begin{array}{l}\text { Mass Discrimination La } \\
\text { Irradiation = UW103 }\end{array}$} & & \multicolumn{2}{|c|}{ Total Fusion Age } & 2.28422 & \pm 0.01349 & 5.22 & \pm 0.03 & & 10 & 0.100 & \pm 0.003 \\
\hline Irradiation = UV & 3 & & & & & & \multicolumn{2}{|l|}{ $\pm 0.59 \%$} & $\pm 0.60 \%$ & & & & \\
\hline \multicolumn{3}{|c|}{$J=0.00124920 \pm 0.00000075$} & & & & & \multicolumn{2}{|c|}{ Minimal External Error } & \pm 0.21 & & & & \\
\hline \multicolumn{3}{|c|}{$\mathrm{FC}=28.201 \pm 0.003 \mathrm{Ma}$} & & & & & \multicolumn{2}{|c|}{ Analytical Error } & \pm 0.03 & & & & \\
\hline
\end{tabular}

(C)

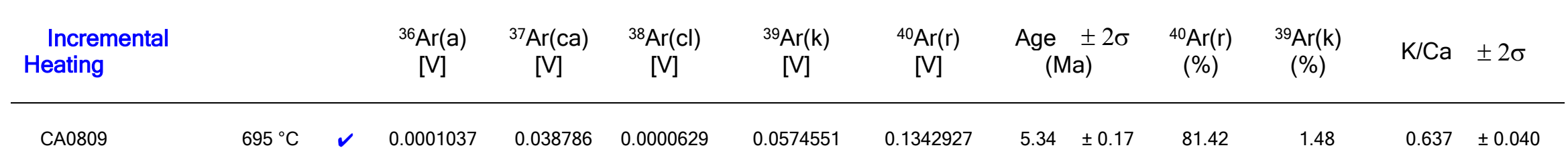




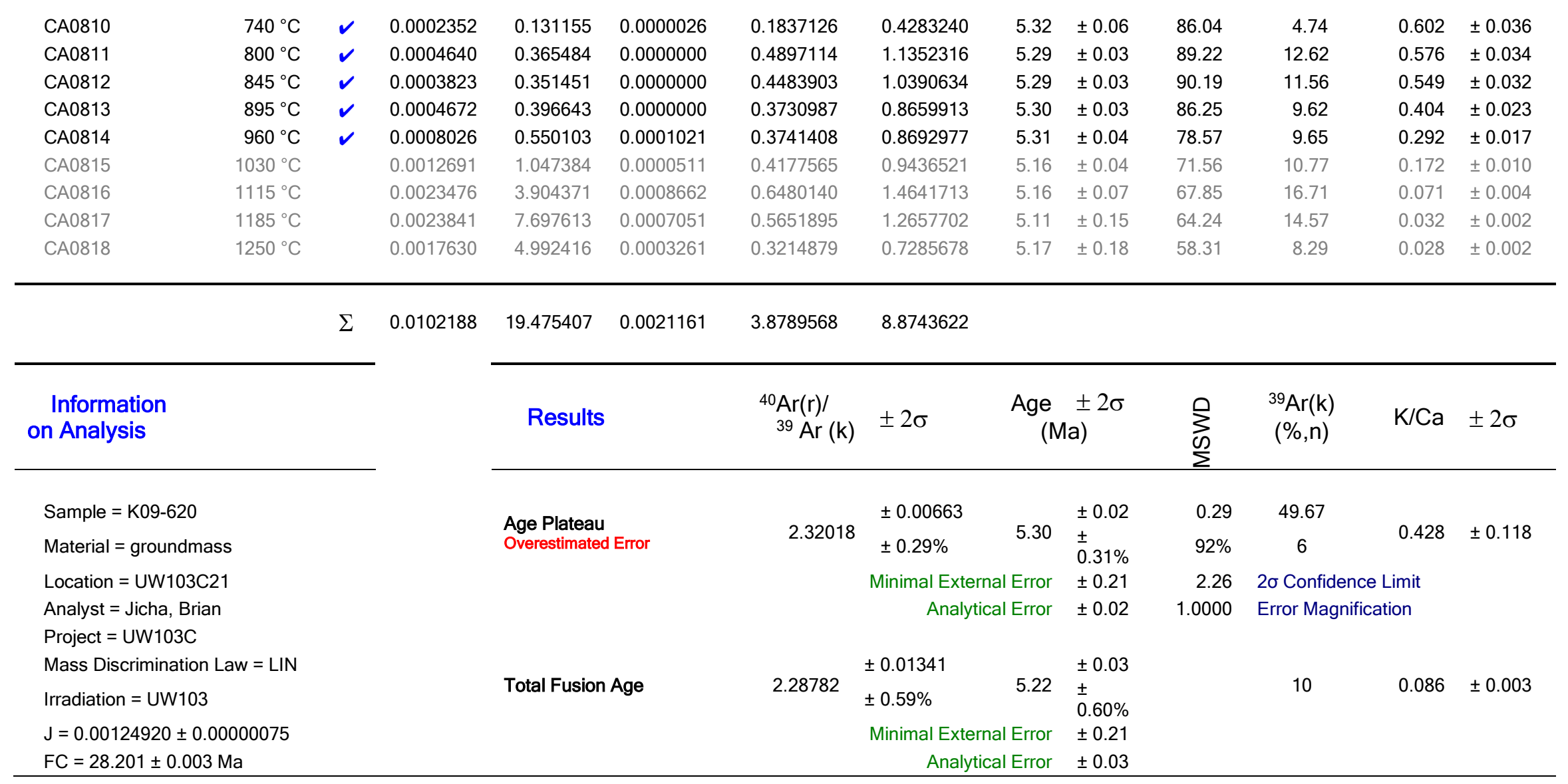


SOM Table S3. Electron microprobe analyses of volcanic glass shards and feldspars from the section at KFS.

\begin{tabular}{|c|c|c|c|c|c|c|c|c|c|c|c|c|c|}
\hline Sample & $\mathrm{SiO}_{2}$ & $\mathrm{TiO}_{2}$ & $\mathrm{ZrO}_{2}$ & $\mathrm{Al}_{2} \mathrm{O}_{3}$ & $\mathrm{Fe}_{2} \mathrm{O}_{3}$ & $\mathrm{MnO}$ & $\mathrm{MgO}$ & $\mathrm{CaO}$ & $\mathrm{Na}_{2} \mathrm{O}$ & $\mathrm{K}_{2} \mathrm{O}$ & $\mathrm{F}$ & $\mathrm{Cl}$ & Sum \\
\hline \multicolumn{14}{|c|}{ Lower Kerichwa Tuff } \\
\hline K09-686 & 62.1 & 0.78 & 0.10 & 14.7 & 5.84 & 0.30 & 0.52 & 0.73 & 6.60 & 6.07 & 0.25 & 0.19 & 98.2 \\
\hline K09-686 & 62.4 & 0.74 & 0.14 & 13.6 & 6.11 & 0.20 & 0.42 & 0.52 & 6.76 & 5.32 & 0.22 & 0.09 & 96.5 \\
\hline K09-686 & 63.0 & 0.82 & 0.25 & 14.0 & 5.89 & 0.22 & 0.36 & 0.55 & 6.81 & 5.37 & 0.15 & 0.12 & 97.6 \\
\hline K09-686 & 62.7 & 0.79 & 0.07 & 14.6 & 5.65 & 0.22 & 0.45 & 0.50 & 6.88 & 6.03 & 0.22 & 0.08 & 98.2 \\
\hline K09-686 & 62.9 & 0.75 & 0.14 & 14.4 & 5.84 & 0.27 & 0.42 & 0.55 & 6.98 & 5.56 & 0.15 & 0.10 & 98.1 \\
\hline K09-686 & 63.3 & 0.74 & 0.13 & 13.7 & 6.10 & 0.27 & 0.39 & 0.57 & 7.10 & 4.97 & 0.17 & 0.12 & 97.6 \\
\hline K09-686 & 62.3 & 0.74 & 0.05 & 15.0 & 5.56 & 0.18 & 0.46 & 0.69 & 7.16 & 5.20 & 0.28 & 0.07 & 97.6 \\
\hline K09-686 & 62.6 & 0.74 & 0.24 & 13.6 & 6.35 & 0.26 & 0.39 & 0.51 & 7.20 & 5.25 & 0.14 & 0.13 & 97.4 \\
\hline Average & 62.7 & 0.76 & 0.14 & 14.2 & 5.92 & 0.24 & 0.43 & 0.58 & 6.94 & 5.47 & 0.20 & 0.11 & 97.7 \\
\hline s.d. & 0.4 & 0.03 & 0.07 & 0.6 & 0.26 & 0.04 & 0.05 & 0.08 & 0.21 & 0.39 & 0.05 & 0.04 & 0.6 \\
\hline
\end{tabular}

Tuffaceous sandstone in unnamed sequence between Kantis Phonolite and Lower Kerichwa Tuff

$\begin{array}{llllllllllllll}\text { K09-619 } & 64.2 & 0.58 & 0.09 & 16.1 & 4.31 & 0.21 & 0.46 & 1.02 & 3.80 & 7.24 & 0.03 & 0.11 & 98.2 \\ \text { K09-619 } & 65.3 & 0.60 & 0.09 & 16.1 & 4.43 & 0.23 & 0.41 & 1.01 & 4.47 & 6.33 & 0.05 & 0.12 & 99.2 \\ \text { K09-619 } & 64.8 & 0.64 & 0.26 & 16.1 & 4.30 & 0.23 & 0.43 & 0.98 & 4.75 & 6.60 & 0.11 & 0.12 & 99.3 \\ \text { K09-619 } & 65.6 & 0.65 & 0.02 & 16.3 & 4.39 & 0.21 & 0.40 & 1.08 & 4.86 & 5.49 & 0.12 & 0.10 & 99.2 \\ \text { K09-619 } & 64.2 & 0.85 & 0.03 & 16.0 & 4.98 & 0.26 & 0.69 & 1.37 & 5.07 & 5.29 & 0.04 & 0.10 & 99.0 \\ \text { K09-619 } & 65.9 & 0.51 & 0.11 & 16.0 & 4.12 & 0.22 & 0.36 & 0.86 & 5.47 & 5.91 & 0.08 & 0.16 & 99.8 \\ \text { K09-619 } & 66.1 & 0.45 & 0.17 & 16.0 & 3.99 & 0.20 & 0.33 & 0.88 & 5.55 & 5.71 & 0.07 & 0.17 & 99.6 \\ \text { K09-619 } & 65.2 & 0.74 & 0.22 & 16.2 & 4.51 & 0.27 & 0.51 & 1.17 & 5.79 & 5.31 & 0.01 & 0.10 & 100.1 \\ \text { K09-619 } & 65.1 & 0.63 & 0.10 & 16.2 & 4.80 & 0.24 & 0.61 & 1.54 & 5.81 & 5.22 & 0.05 & 0.12 & 100.4 \\ \text { K09-619 } & 66.5 & 0.59 & 0.17 & 16.2 & 4.17 & 0.23 & 0.33 & 0.84 & 5.84 & 5.35 & 0.15 & 0.15 & 100.5 \\ \text { K09-619 } & 64.4 & 0.75 & 0.09 & 16.1 & 4.82 & 0.22 & 0.60 & 1.33 & 5.84 & 5.01 & 0.09 & 0.08 & 99.5 \\ \text { K09-619 } & 66.0 & 0.50 & 0.09 & 16.1 & 4.14 & 0.24 & 0.32 & 0.83 & 5.87 & 5.45 & 0.07 & 0.17 & 99.8 \\ \text { K09-619 } & 65.8 & 0.62 & 0.15 & 16.2 & 4.32 & 0.18 & 0.39 & 0.93 & 5.90 & 5.42 & 0.10 & 0.12 & 100.1 \\ \text { K09-619 } & 66.0 & 0.51 & 0.21 & 16.1 & 4.28 & 0.26 & 0.32 & 0.92 & 5.92 & 5.35 & 0.05 & 0.13 & 100.0 \\ \text { K09-619 } & 65.6 & 0.65 & 0.11 & 16.0 & 4.16 & 0.23 & 0.41 & 0.97 & 5.95 & 5.63 & 0.07 & 0.13 & 99.9 \\ \text { K09-619 } & 66.0 & 0.51 & 0.24 & 15.8 & 4.23 & 0.20 & 0.37 & 0.85 & 5.96 & 5.21 & 0.11 & 0.17 & 99.7 \\ \text { K09-619 } & 65.8 & 0.63 & 0.25 & 16.1 & 4.17 & 0.22 & 0.32 & 0.88 & 6.03 & 5.44 & 0.03 & 0.15 & 100.0 \\ \text { K09-619 } & 63.1 & 1.12 & 0.12 & 16.2 & 5.29 & 0.24 & 0.89 & 1.68 & 6.15 & 5.02 & 0.06 & 0.07 & 100.1 \\ \text { K09-619 } & 65.7 & 0.62 & 0.19 & 16.1 & 4.42 & 0.22 & 0.43 & 0.89 & 6.26 & 5.27 & 0.12 & 0.14 & 100.3 \\ \text { Average } & \mathbf{6 5 . 3} & \mathbf{0 . 6 4} & \mathbf{0 . 1 4} & \mathbf{1 6 . 1} & \mathbf{4 . 4 1} & \mathbf{0 . 2 3} & \mathbf{0 . 4 5} & \mathbf{1 . 0 5} & \mathbf{5 . 5 4} & \mathbf{5 . 5 9} & \mathbf{0 . 0 8} & \mathbf{0 . 1 3} & \mathbf{9 9 . 7} \\ \text { s.d. } & \mathbf{0 . 9} & \mathbf{0 . 1 5} & \mathbf{0 . 0 7} & \mathbf{0 . 1} & \mathbf{0 . 3 3} & \mathbf{0 . 0 2} & \mathbf{0 . 1 5} & \mathbf{0 . 2 5} & \mathbf{0 . 6 5} & \mathbf{0 . 5 7} & \mathbf{0 . 0 4} & \mathbf{0 . 0 3} & \mathbf{0 . 6}\end{array}$

\begin{tabular}{|c|c|c|c|c|c|c|c|c|c|c|c|c|c|}
\hline Santis Tuff & & & & & & & & & & & & & \\
\hline K09-618B & 61.2 & 1.00 & 0.08 & 14.5 & 6.47 & 0.30 & 0.59 & 0.92 & 5.25 & 5.31 & 0.23 & 0.07 & 95.9 \\
\hline K09-618B & 63.1 & 0.90 & 0.11 & 14.3 & 6.60 & 0.29 & 0.51 & 0.88 & 5.26 & 5.16 & 0.26 & 0.08 & 97.5 \\
\hline K09-618B & 63.6 & 0.95 & 0.05 & 14.1 & 6.64 & 0.31 & 0.54 & 0.85 & 4.95 & 5.05 & 0.30 & 0.08 & 97.4 \\
\hline K09-618B & 63.1 & 0.92 & 0.11 & 14.0 & 6.55 & 0.27 & 0.56 & 0.89 & 4.91 & 5.20 & 0.26 & 0.09 & 96.9 \\
\hline К09-618B & 64.3 & 0.88 & 0.04 & 14.2 & 6.47 & 0.26 & 0.59 & 0.85 & 5.18 & 5.11 & 0.28 & 0.08 & 98.3 \\
\hline K09-618B & 63.2 & 0.97 & 0.06 & 14.0 & 6.72 & 0.29 & 0.53 & 0.87 & 4.64 & 5.04 & 0.32 & 0.09 & 96.8 \\
\hline K09-618B & 64.3 & 0.96 & 0.08 & 13.9 & 6.82 & 0.28 & 0.56 & 0.89 & 5.27 & 5.11 & 0.23 & 0.09 & 98.5 \\
\hline K09-618B & 64.1 & 0.93 & 0.05 & 14.1 & 6.62 & 0.28 & 0.57 & 0.89 & 5.14 & 5.21 & 0.21 & 0.08 & 98.2 \\
\hline K09-618B & 64.1 & 0.91 & 0.11 & 14.1 & 6.77 & 0.27 & 0.49 & 0.90 & 5.18 & 5.09 & 0.21 & 0.09 & 98.2 \\
\hline K09-618B & 64.2 & 0.90 & 0.15 & 13.9 & 6.56 & 0.32 & 0.56 & 0.89 & 5.17 & 5.25 & 0.21 & 0.08 & 98.2 \\
\hline K09-618B & 64.3 & 0.91 & 0.14 & 14.0 & 6.67 & 0.26 & 0.53 & 0.90 & 5.50 & 5.09 & 0.25 & 0.09 & 98.6 \\
\hline K09-618B & 64.9 & 0.97 & 0.15 & 14.2 & 6.57 & 0.32 & 0.55 & 0.88 & 5.21 & 5.11 & 0.19 & 0.08 & 99.1 \\
\hline K09-618B & 64.4 & 0.97 & 0.03 & 14.1 & 6.48 & 0.29 & 0.57 & 0.89 & 4.77 & 5.12 & 0.28 & 0.08 & 97.9 \\
\hline K09-618B & 64.4 & 0.91 & 0.05 & 14.1 & 6.78 & 0.26 & 0.48 & 0.86 & 5.02 & 5.12 & 0.29 & 0.07 & 98.4 \\
\hline K09-618B & 65.1 & 0.82 & 0.05 & 14.2 & 6.71 & 0.28 & 0.53 & 0.90 & 5.05 & 5.13 & 0.25 & 0.08 & 99.1 \\
\hline K09-618B & 64.5 & 0.89 & 0.03 & 14.0 & 6.55 & 0.29 & 0.54 & 0.87 & 4.88 & 5.05 & 0.25 & 0.09 & 98.0 \\
\hline K09-618B & 64.6 & 0.91 & 0.17 & 14.1 & 6.74 & 0.24 & 0.57 & 0.93 & 5.24 & 5.26 & 0.24 & 0.08 & 99.1 \\
\hline K09-618B & 64.9 & 0.95 & 0.07 & 13.9 & 6.53 & 0.28 & 0.48 & 0.88 & 4.65 & 5.05 & 0.27 & 0.08 & 98.1 \\
\hline K09-618B & 64.8 & 0.97 & 0.17 & 14.3 & 6.67 & 0.31 & 0.55 & 0.92 & 5.32 & 5.11 & 0.30 & 0.08 & 99.5 \\
\hline Average & 64.1 & 0.93 & 0.09 & 14.1 & 6.63 & 0.28 & 0.54 & 0.89 & 5.09 & 5.13 & 0.25 & 0.08 & 98.1 \\
\hline s.d. & 0.9 & 0.04 & 0.05 & 0.2 & 0.11 & 0.02 & 0.03 & 0.02 & 0.23 & 0.08 & 0.04 & 0.01 & 0.9 \\
\hline
\end{tabular}




\begin{tabular}{lllllllll} 
Sample & $\mathrm{SiO}_{2}$ & $\mathrm{Al}_{2} \mathrm{O}_{3}$ & $\mathrm{Fe}_{2} \mathrm{O}_{3}$ & $\mathrm{CaO}$ & $\mathrm{BaO}$ & $\mathrm{Na}_{2} \mathrm{O}$ & $\mathrm{K}_{2} \mathrm{O}$ & Sum \\
\hline $\mathrm{K} 09-686$ & 64.9 & 19.3 & 0.30 & 0.74 & 0.00 & 7.26 & 6.07 & 98.6 \\
$\mathrm{~K} 09-686$ & 64.9 & 19.2 & 0.40 & 0.42 & 0.07 & 7.15 & 6.44 & 98.7 \\
$\mathrm{~K} 09-686$ & 66.2 & 18.4 & 0.40 & 0.23 & 0.00 & 6.79 & 6.74 & 98.8 \\
$\mathrm{~K} 09-686$ & 65.1 & 19.7 & 0.29 & 1.08 & 0.00 & 8.16 & 4.39 & 98.8 \\
$\mathrm{~K} 09-686$ & 65.3 & 19.1 & 0.34 & 0.65 & 0.00 & 7.19 & 6.15 & 98.9 \\
$\mathrm{~K} 09-686$ & 66.0 & 18.6 & 0.41 & 0.16 & 0.00 & 6.84 & 6.80 & 98.9 \\
$\mathrm{~K} 09-686$ & 64.9 & 19.2 & 0.37 & 0.73 & 0.00 & 7.55 & 6.09 & 98.9 \\
$\mathrm{~K} 09-686$ & 65.8 & 18.9 & 0.32 & 0.24 & 0.00 & 7.21 & 6.69 & 99.1 \\
$\mathrm{~K} 09-686$ & 65.9 & 18.7 & 0.33 & 0.32 & 0.00 & 7.41 & 6.46 & 99.2 \\
$\mathrm{~K} 09-686$ & 66.3 & 18.7 & 0.49 & 0.18 & 0.00 & 6.86 & 7.03 & 99.5 \\
$\mathrm{~K} 09-686$ & 66.4 & 18.7 & 0.38 & 0.15 & 0.00 & 7.21 & 6.73 & 99.7 \\
$\mathrm{~K} 09-686$ & 66.4 & 18.6 & 0.47 & 0.14 & 0.00 & 7.43 & 6.59 & 99.7 \\
$\mathrm{~K} 09-686$ & 66.1 & 18.9 & 0.31 & 0.39 & 0.00 & 7.37 & 6.54 & 99.8 \\
$\mathrm{~K} 09-686$ & 66.4 & 18.5 & 0.43 & 0.17 & 0.00 & 7.37 & 6.83 & 99.8 \\
$\mathrm{~K} 09-686$ & 66.2 & 19.0 & 0.32 & 0.49 & 0.00 & 7.30 & 6.41 & 99.9 \\
$\mathrm{~K} 09-686$ & 66.8 & 18.7 & 0.43 & 0.14 & 0.00 & 7.36 & 6.64 & 100.1 \\
$\mathrm{~K} 09-686$ & 66.5 & 18.5 & 0.48 & 0.17 & 0.00 & 7.35 & 6.90 & 100.1 \\
$\mathrm{~K} 09-686$ & 66.8 & 19.0 & 0.42 & 0.33 & 0.01 & 7.20 & 6.74 & 100.5 \\
\hline
\end{tabular}


SOM Table S4. U-Pb isotopic data for zircon crystals (samples KY13011903 and KY13012102, obtained from the fossiliferous bed) determined by LA-ICP-MS.

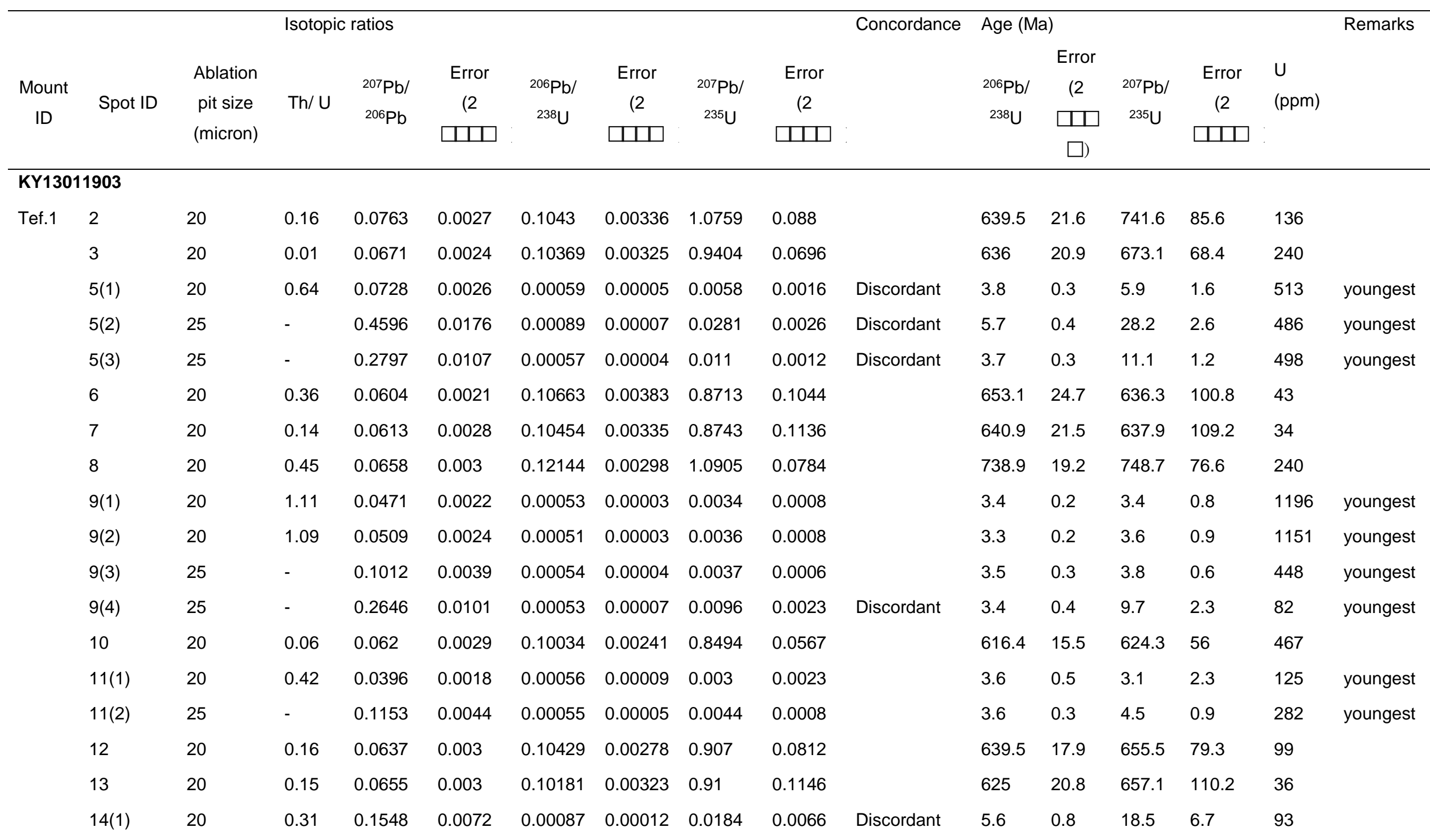


$\begin{array}{llllllllllllll}14(2) & 20 & 0.31 & 0.0167 & 0.0008 & 0.00178 & 0.00015 & 0.0041 & 0.0026 & 11.5 & 1 & 4.1 & 2.6 & 133\end{array}$

Secondary standard (OD-3: ca. 33Ma)

\begin{tabular}{|c|c|c|c|c|c|c|c|c|c|c|c|c|}
\hline OD3 2-4 & 25 & - & 0.0955 & 0.0037 & 0.00502 & 0.00033 & 0.033 & 0.0027 & 32.3 & 2.1 & 33 & 2.8 \\
\hline OD3 2-5 & 25 & - & 0.0949 & 0.0036 & 0.00514 & 0.00034 & 0.0336 & 0.0028 & 33 & 2.2 & 33.5 & 2.8 \\
\hline OD3 2-6 & 25 & - & 0.093 & 0.0036 & 0.0051 & 0.00034 & 0.0327 & 0.0027 & 32.8 & 2.2 & 32.7 & 2.7 \\
\hline OD3 2-7 & 25 & - & 0.0935 & 0.0036 & 0.00526 & 0.00036 & 0.0339 & 0.0036 & 33.8 & 2.3 & 33.8 & 3.7 \\
\hline OD3 2-8 & 25 & - & 0.1095 & 0.0042 & 0.00518 & 0.00035 & 0.039 & 0.0037 & 33.3 & 2.3 & 38.9 & 3.8 \\
\hline
\end{tabular}

\begin{tabular}{|c|c|c|c|c|c|c|c|c|c|c|c|c|c|c|c|c|}
\hline \multicolumn{17}{|c|}{ KY13012102 } \\
\hline \multirow[t]{16}{*}{ Tef.1 } & 1 & 20 & 0.24 & 0.0583 & 0.0022 & 0.10574 & 0.00623 & 0.8302 & 0.1312 & & 648 & 40 & 613.7 & 125.2 & 19 & \\
\hline & 2 & 20 & 0.01 & 0.0603 & 0.0023 & 0.09895 & 0.00512 & 0.8043 & 0.039 & & 608.3 & 32.9 & 599.2 & 38.8 & 252 & \\
\hline & 3 & 20 & 0.17 & 0.0591 & 0.0022 & 0.10012 & 0.00542 & 0.7969 & 0.0778 & & 615.1 & 34.9 & 595.1 & 76.1 & 52 & \\
\hline & 4 & 20 & 0.27 & 0.0573 & 0.0022 & 0.10098 & 0.00579 & 0.7794 & 0.1097 & & 620.2 & 37.2 & 585.1 & 105.7 & 25 & \\
\hline & 5 & 20 & 0.18 & 0.0695 & 0.0026 & 0.10055 & 0.00562 & 0.9408 & 0.1096 & & 617.6 & 36.1 & 673.3 & 105.6 & 33 & \\
\hline & 6 & 20 & 0.19 & 0.0651 & 0.0025 & 0.09869 & 0.00596 & 0.8662 & 0.1438 & & 606.7 & 38.3 & 633.5 & 136.4 & 17 & \\
\hline & $7(1)$ & 20 & 2.16 & 0.0328 & 0.0012 & 0.00099 & 0.00009 & 0.0044 & 0.0019 & & 6.4 & 0.6 & 4.4 & 1.9 & 254 & \\
\hline & $7(2)$ & 20 & 2.27 & 0.0523 & 0.002 & 0.0011 & 0.0001 & 0.0077 & 0.0027 & & 7.1 & 0.7 & 7.8 & 2.7 & 233 & \\
\hline & 8 & 20 & 0.24 & 0.0703 & 0.0027 & 0.13967 & 0.0073 & 1.3231 & 0.0857 & & 842.8 & 46.9 & 855.9 & 83.5 & 99 & \\
\hline & 9 & 20 & 0.21 & 0.0616 & 0.0023 & 0.10382 & 0.00564 & 0.861 & 0.0857 & & 636.7 & 36.2 & 630.7 & 83.5 & 48 & \\
\hline & 10 & 20 & 0.28 & 0.061 & 0.0023 & 0.10276 & 0.00555 & 0.8446 & 0.0801 & & 630.6 & 35.7 & 621.7 & 78.2 & 54 & \\
\hline & 11 & 20 & 0.1 & 0.0613 & 0.0023 & 0.10586 & 0.00552 & 0.8736 & 0.0533 & & 648.7 & 35.5 & 637.5 & 52.7 & 139 & \\
\hline & 12 & 20 & 0.3 & 0.185 & 0.007 & 0.50375 & 0.02633 & 12.5564 & 1.0301 & & $\begin{array}{l}2629 . \\
9\end{array}$ & 167.5 & 2647 & 719 & 36 & \\
\hline & $13(1)$ & 20 & 1.32 & 0.0801 & 0.003 & 0.00055 & 0.00004 & 0.0059 & 0.0012 & Discordance & 3.5 & 0.3 & 6 & 1.2 & 939 & youngest \\
\hline & $13(2)$ & 25 & - & 0.0928 & 0.0018 & 0.00055 & 0.00002 & 0.0035 & 0.0004 & & 3.6 & 0.1 & 3.6 & 0.4 & 1136 & youngest \\
\hline & $13(3)$ & 25 & - & 0.1006 & 0.0039 & 0.00051 & 0.00004 & 0.0035 & 0.0004 & & 3.3 & 0.2 & 3.6 & 0.4 & 1106 & youngest \\
\hline
\end{tabular}




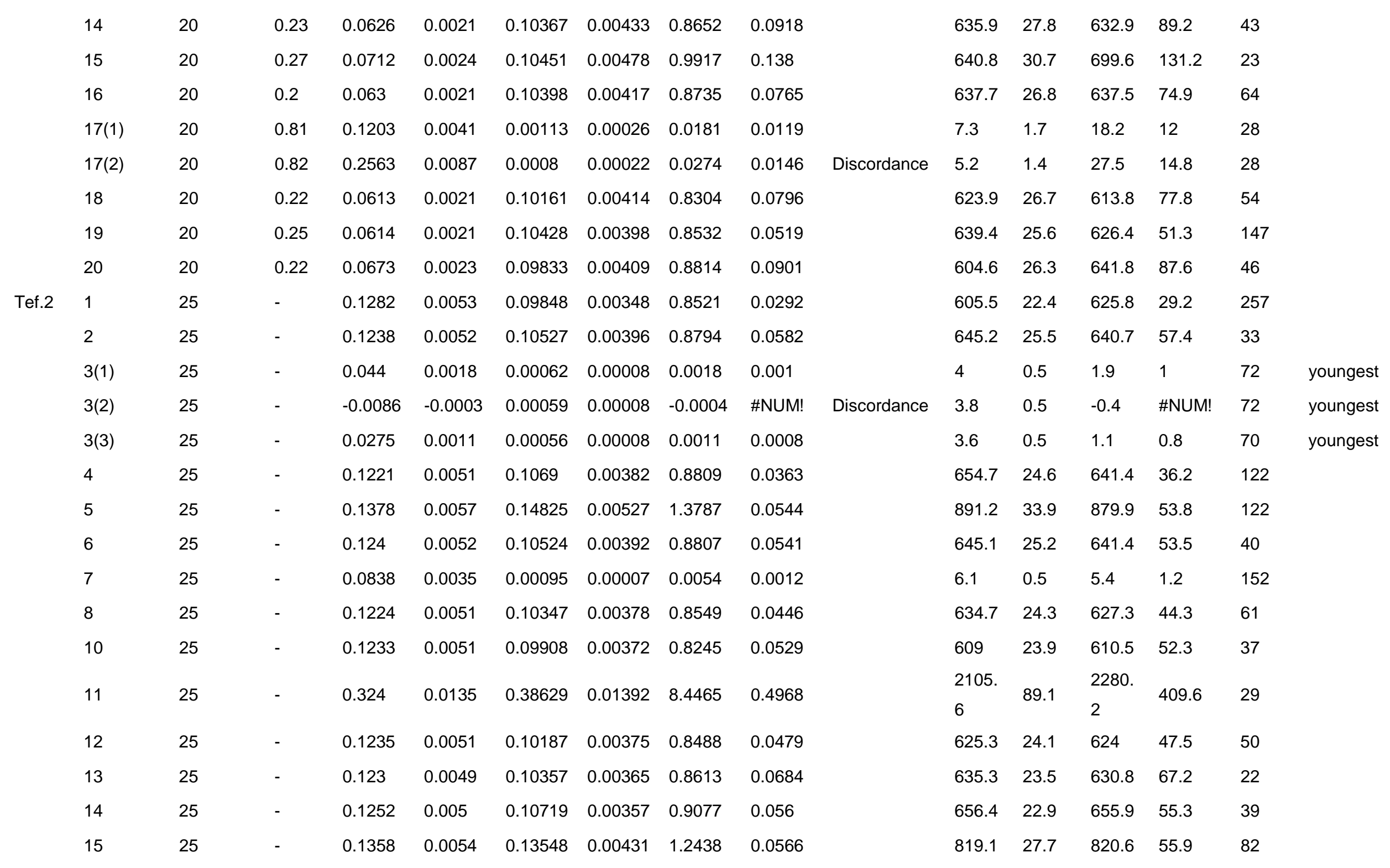




\begin{tabular}{|c|c|c|c|c|c|c|c|c|c|c|c|c|c|c|c|}
\hline 16 & 25 & - & 0.1363 & 0.0055 & 0.31601 & 0.0098 & 2.9136 & 0.0989 & & $\begin{array}{l}1770 . \\
2\end{array}$ & 62.8 & $\begin{array}{l}1385 . \\
5\end{array}$ & 95.7 & 230 & \\
\hline $17(1)$ & 25 & - & 0.1347 & 0.0054 & 0.00058 & 0.00005 & 0.0053 & 0.0012 & \multirow[t]{7}{*}{ Discordance } & 3.8 & 0.3 & 5.4 & 1.2 & 150 & youngest \\
\hline $17(2)$ & 25 & - & 0.0962 & 0.0037 & 0.00058 & 0.00007 & 0.0039 & 0.0012 & & 3.8 & 0.4 & 3.9 & 1.2 & 116 & youngest \\
\hline $17(3)$ & 25 & - & 0.1297 & 0.005 & 0.00061 & 0.00007 & 0.0055 & 0.0016 & & 3.9 & 0.5 & 5.5 & 1.6 & 91 & youngest \\
\hline 18 & 25 & - & 0.136 & 0.0054 & 0.1395 & 0.00439 & 1.2834 & 0.0525 & & 841.8 & 28.3 & 838.4 & 51.9 & 117 & \\
\hline 19 & 25 & - & 0.1224 & 0.0049 & 0.10559 & 0.0034 & 0.8743 & 0.0431 & & 647.1 & 21.9 & 637.9 & 42.9 & 73 & \\
\hline 20 & 25 & - & 0.0938 & 0.0038 & 0.00051 & 0.00003 & 0.0032 & 0.0005 & & 3.3 & 0.2 & 3.3 & 0.5 & 618 & youngest \\
\hline 21 & 25 & - & 0.1238 & 0.0050 & 0.10460 & 0.00343 & 0.8759 & 0.0498 & & 641.3 & 22.1 & 638.7 & 49.3 & 49 & \\
\hline $22(1)$ & 25 & - & 0.2478 & 0.0099 & 0.00068 & 0.00006 & 0.0114 & 0.0020 & \multirow[t]{3}{*}{ Discordance } & 4.4 & 0.4 & 11.5 & 2.0 & 124 & \\
\hline $22(2)$ & 25 & - & 0.0024 & 0.0001 & 0.00278 & 0.00023 & 0.0005 & 0.0005 & & 17.9 & 1.5 & 0.5 & 0.5 & 75 & \\
\hline 23(1) & 25 & - & 0.0445 & 0.0018 & 0.00050 & 0.00005 & 0.0015 & 0.0007 & & 3.2 & 0.3 & 1.5 & 0.7 & 118 & youngest \\
\hline $23(2)$ & 25 & - & 0.4766 & 0.0183 & 0.00077 & 0.00009 & 0.0252 & 0.0039 & Discordance & 4.9 & 0.6 & 25.2 & 3.9 & 89 & youngest \\
\hline 23(3) & 25 & - & 0.6867 & 0.0263 & 0.00082 & 0.00009 & 0.0388 & 0.0053 & Discordance & 5.3 & 0.6 & 38.7 & 5.4 & 82 & youngest \\
\hline $23(4)$ & 25 & - & 0.6385 & 0.0245 & 0.00099 & 0.00011 & 0.0434 & 0.0057 & \multirow[t]{3}{*}{ Discordance } & 6.4 & 0.7 & 43.1 & 5.8 & 81 & \multirow[t]{3}{*}{ youngest } \\
\hline 24 & 25 & - & 0.1359 & 0.0054 & 0.14092 & 0.00449 & 1.2956 & 0.0603 & & 849.9 & 28.9 & 843.8 & 59.5 & 76 & \\
\hline 29 & 25 & - & 0.1370 & 0.0055 & 0.15181 & 0.00481 & 1.4069 & 0.0635 & & 911.1 & 31.0 & 891.8 & 62.5 & 82 & \\
\hline \multicolumn{16}{|c|}{ dary standard (OD-3: ca.33Ma) } \\
\hline OD3 1-1 & 25 & - & 0.1103 & 0.0046 & 0.00512 & 0.00022 & 0.0381 & 0.0029 & \multirow[t]{6}{*}{ Discordance } & 32.9 & 1.4 & 38.0 & 3.0 & 222 & \\
\hline OD3 1-2 & 25 & - & 0.0930 & 0.0039 & 0.00509 & 0.00026 & 0.0319 & 0.0042 & & 32.7 & 1.7 & 31.9 & 4.2 & 83 & \\
\hline OD3 1-3 & 25 & - & 0.0972 & 0.0041 & 0.00520 & 0.00022 & 0.0342 & 0.0029 & & 33.5 & 1.4 & 34.1 & 2.9 & 202 & \\
\hline OD3 2-1 & 25 & - & 0.0783 & 0.0031 & 0.00511 & 0.00025 & 0.0271 & 0.0038 & & 32.9 & 1.6 & 27.1 & 3.8 & 84 & \\
\hline OD3 2-2 & 25 & - & 0.0956 & 0.0037 & 0.00489 & 0.00033 & 0.0322 & 0.0029 & & 31.5 & 2.1 & 32.2 & 2.9 & 487 & \\
\hline OD3 2-3 & 25 & - & 0.0946 & 0.0036 & 0.00493 & 0.00032 & 0.0321 & 0.0025 & & 31.7 & 2.1 & 32.1 & 2.6 & 1297 & \\
\hline
\end{tabular}


SOM Table S6. Isotopic analyses of enamel from fossil mammals at the Kantis Fossil Site. (a) KFS individual data and (b) statistics of KFS, Lothagam (Kaiyumung Mb; $3.2 \mathrm{Ma}$ ), Laetoli (Upper Laetoli Beds; 3.8-3.5 Ma), Dikika (Sidi Hakoma Mb; 3.4 Ma) and Koobi Fora (Lokochot Mb; 3.5 Ma).

\begin{tabular}{|c|c|c|c|c|}
\hline $\begin{array}{l}\text { Accession } \\
\text { number } \\
\text { KNM-RK }\end{array}$ & Order & Family & Species & $\delta^{13} \mathrm{C}(\%)$ \\
\hline 50004 & Artiodactyla & Hippopotamidae & aff. Hippopotamus cf. protamphibius & -0.73 \\
\hline 50005 & & & aff. Hippopotamus cf. protamphibius & -0.19 \\
\hline 50023 & & & aff. Hippopotamus cf. protamphibius & -3.47 \\
\hline 50035 & & & aff. Hippopotamus cf. protamphibius & 0.38 \\
\hline 50037 & & & aff. Hippopotamus cf. protamphibius & -4.50 \\
\hline 50042 & & & aff. Hippopotamus cf. protamphibius & -1.47 \\
\hline 50058 & & & aff. Hippopotamus cf. protamphibius & -2.43 \\
\hline 50065 & & & aff. Hippopotamus cf. protamphibius & 0.26 \\
\hline 50554 & & & aff. Hippopotamus cf. protamphibius & -0.69 \\
\hline 50591 & & & aff. Hippopotamus cf. protamphibius & -0.58 \\
\hline 50613 & & & aff. Hippopotamus cf. protamphibius & -3.37 \\
\hline 51174 & & & aff. Hippopotamus cf. protamphibius & -2.77 \\
\hline 51215 & & & aff. Hippopotamus cf. protamphibius & -3.46 \\
\hline 51225 & & & aff. Hippopotamus cf. protamphibius & -0.96 \\
\hline 51226 & & & aff. Hippopotamus cf. protamphibius & -4.72 \\
\hline 51378 & & & aff. Hippopotamus cf. protamphibius & -3.37 \\
\hline 51381 & & & aff. Hippopotamus cf. protamphibius & -1.03 \\
\hline 55276 & & & aff. Hippopotamus cf. protamphibius & -1.65 \\
\hline 55277 & & & aff. Hippopotamus cf. protamphibius & -5.70 \\
\hline 55280 & & & aff. Hippopotamus cf. protamphibius & -0.93 \\
\hline 55275 & & & aff. Hippopotamus cf. protamphibius & -0.92 \\
\hline 55282 & & & aff. Hippopotamus cf. protamphibius & -2.09 \\
\hline 55283 & & & aff. Hippopotamus cf. protamphibius & -1.59 \\
\hline 55284 & & & aff. Hippopotamus cf. protamphibius & -5.32 \\
\hline 55285 & & & aff. Hippopotamus cf. protamphibius & -2.03 \\
\hline 55286 & & & aff. Hippopotamus cf. protamphibius & -1.88 \\
\hline 55287 & & & aff. Hippopotamus cf. protamphibius & -1.09 \\
\hline 55288 & & & aff. Hippopotamus cf. protamphibius & -1.58 \\
\hline 55290 & & & aff. Hippopotamus cf. protamphibius & -5.78 \\
\hline 55432 & & & aff. Hippopotamus cf. protamphibius & -2.70 \\
\hline 48738 & Artiodactyla & Bovidae & Alcelaphini & -4.32 \\
\hline 48746 & & & Alcelaphini & -10.33 \\
\hline 48750 & & & Bovini & -0.59 \\
\hline 50002 & & & Aepyceros & -4.03 \\
\hline 50062 & & & (probably) Bovini & 1.61 \\
\hline 50066 & & & Alcelaphini or Aepyceros & 0.34 \\
\hline 50458 & & & Alcelaphini & -4.10 \\
\hline 50476 & & & Alcelaphini & -3.81 \\
\hline 50503 & & & Bovini & 0.44 \\
\hline 50518 & & & Alcelaphini & -2.55 \\
\hline
\end{tabular}


50628

51159

51196

\begin{tabular}{|c|c|c|}
\hline 48744 & Artiodactyla & Suidae \\
\hline 48749 & & \\
\hline 50051 & & \\
\hline 50069 & & \\
\hline 50494 & & \\
\hline 50539 & & \\
\hline 50621 & & \\
\hline 54221 & & \\
\hline 54226 & & \\
\hline 54220 & & \\
\hline 52994 & & \\
\hline 54224 & & \\
\hline 54223 & & \\
\hline 54222 & & \\
\hline 55266 & & \\
\hline 55435 & & \\
\hline 55637 & & \\
\hline 55642 & & \\
\hline 55648 & & \\
\hline 55684 & & \\
\hline 55650 & & \\
\hline 55641 & & \\
\hline 52981 & Artiodactyla & Giraffidae \\
\hline 50499 & & \\
\hline 50534 & & \\
\hline 55335 & & \\
\hline 56128 & & \\
\hline
\end{tabular}

49989

50000

50585

50601

50692

51220

51274

56109

56108

56115

56114

56112

56110

56113

56111

55339

53790
Aepyceros $\quad-6.87$

Alcelaphini $\quad-5.54$

Bovini $\quad-4.22$

Notochoerus cf. euilus $\quad-1.12$

Notochoerus cf. euilus $\quad-0.77$

Notochoerus cf. euilus $\quad-0.84$

Notochoerus cf. euilus $\quad-0.45$

Notochoerus cf. euilus $\quad-0.99$

Notochoerus cf. euilus $\quad-0.23$

Notochoerus cf. euilus $\quad-1.78$

Notochoerus cf. euilus $\quad-2.08$

Notochoerus cf. euilus $\quad-0.39$

Notochoerus cf. euilus $\quad-1.34$

Notochoerus cf. euilus $\quad-0.94$

Notochoerus cf. euilus $\quad-1.71$

Notochoerus cf. euilus $\quad-0.98$

Notochoerus cf. euilus $\quad 0.02$

Notochoerus cf. euilus $\quad-1.03$

Notochoerus cf. euilus $\quad-1.05$

Notochoerus cf. euilus $\quad-0.03$

Notochoerus cf. euilus $\quad-1.30$

Notochoerus cf. euilus $\quad-0.30$

Notochoerus cf. euilus $\quad-0.69$

Notochoerus cf. euilus $\quad-0.59$

Notochoerus cf. euilus $\quad-0.40$

Sivatherium $\quad-11.16$

Sivatherium $\quad-10.69$

Sivatherium $\quad-10.79$

Sivatherium $\quad-11.09$

Sivatherium $\quad-14.04$

Perissodactyla Rhinocerotidae

Ceratotherium mauritanicum $\quad-2.83$

Ceratotherium mauritanicum $\quad-3.21$

Ceratotherium mauritanicum $\quad-4.45$

Ceratotherium mauritanicum $\quad-4.81$

Ceratotherium mauritanicum $\quad-4.94$

Ceratotherium mauritanicum $\quad-5.35$

Ceratotherium mauritanicum $\quad-4.56$

Ceratotherium mauritanicum $\quad-7.33$

Ceratotherium mauritanicum $\quad-5.40$

Ceratotherium mauritanicum $\quad-4.42$

Ceratotherium mauritanicum $\quad-4.84$

Ceratotherium mauritanicum $\quad-6.14$

Ceratotherium mauritanicum $\quad-8.07$

Ceratotherium mauritanicum $\quad-6.92$

Ceratotherium mauritanicum $\quad-6.07$

Diceros sp. $\quad-5.61$

Ceratotherium mauritanicum $\quad-5.65$ 
53810

53798

53806

53809

53807

53808

52979

52980

53540

49993

50034

50526

51238

51270

51390

55350

55351

55352

55356

55500

56119

56118

56117

56116

52988

48735

56120

56127

57541
Ceratotherium mauritanicum

Ceratotherium mauritanicum

Ceratotherium mauritanicum

Ceratotherium mauritanicum

Ceratotherium mauritanicum

Ceratotherium mauritanicum

Ceratotherium mauritanicum

Ceratotherium mauritanicum

Ceratotherium mauritanicum

Hipparion sp.

Hipparion sp.

Hipparion sp.

Hipparion sp.

Hipparion sp.

Hipparion sp.

Hipparion sp.

Hipparion sp.

Hipparion sp.

Hipparion sp.

Hipparion sp.

Hipparion sp.

Hipparion sp.

Hipparion sp.

Hipparion sp.

indet

indet

indet

indet

indet
$-4.71$

$-4.04$

$-3.85$

$-5.02$

$-4.85$

$-4.50$

$-6.70$

$-5.93$

$-4.36$

$-0.37$

0.15

$-3.86$

$-1.21$

$-0.88$

0.00

0.22

$-0.47$

$-0.81$

0.31

$-0.53$

$-2.32$

$-0.99$

$-0.35$

0.77

$-1.28$

$-3.26$

$-3.37$

$-2.25$

$-2.17$ 